Portland State University

PDXScholar

Fall 9-11-2015

\title{
Centralia, Collective Memory, and the Tragedy of 1919
}

Shawn T. Daley

Portland State University

Follow this and additional works at: https://pdxscholar.library.pdx.edu/open_access_etds

Part of the Labor History Commons, and the United States History Commons Let us know how access to this document benefits you.

\section{Recommended Citation}

Daley, Shawn T., "Centralia, Collective Memory, and the Tragedy of 1919" (2015). Dissertations and Theses. Paper 2576.

https://doi.org/10.15760/etd.2574

This Thesis is brought to you for free and open access. It has been accepted for inclusion in Dissertations and Theses by an authorized administrator of PDXScholar. Please contact us if we can make this document more accessible: pdxscholar@pdx.edu. 
Centralia, Collective Memory, and the Tragedy of 1919

by

Shawn T. Daley

A thesis submitted in partial fulfillment of the requirements for the degree of

Master of Arts

in

History

Thesis Committee

David Johnson, Chair

Katrine Barber

Ken Ruoff

Gayle Thieman

Portland State University

2015 
(C) 2015 Shawn T. Daley 


\section{Abstract}

The Centralia Tragedy of 1919 has been represented in numerous works over the course of the past 100 years. The vast majority of them concern the events of the day of the Tragedy, November 11, 1919, and whether a small group of Wobblies - members of a union group known as the International Workers of the World (I.W.W.) - opened fire on a group of parading American Legionnaires. This particular element, whether or not the Wobblies opened fire on the Legionnaires or the Legionnaires actually charged the hall where the Wobblies were staying, has generated significant concern in academic and popular literature since it occurred.

This study is less concerned with the events of the day itself, accepting that the full truth might not ever be known. It is instead focused on the collective remembering of that event, and how those recollections splintered into several strands of memory in the nearly 96 years since. It categorizes those strands into three specific ones: the official memory framework, the Labor countermemory framework, and the academic framework.

Each strand developed from early in the Tragedy's history, starting with authors and adherents in the days after a 1920 trial. That trial, which declared the Wobblies guilty of the deaths of four Legionnaires while not holding anyone accountable for the lynching of Wobbly Wesley Everest, generated ample discord among Centralians. This lack of closure prompted the various aggrieved parties to produce books, pamphlets, speeches, protests and even a famed statue in Centralia's main park. Over time, the various perspectives congealed into the distinct strands of memory, which often flared up in conflict between 1930 and the present day. 
Ultimately, this thesis argues that there has been a distinct divergence of memory and countermemory in this Washington town, and that three frameworks of understanding the Centralia Tragedy emerged over the course of the past 96 years. As such, this thesis offers a unique perspective on the Tragedy, similar to but unlike previous scholarship, with the hope of encouraging new avenues for study for study of the Tragedy and events resembling it. 


\section{Dedication}

This thesis is dedicated to my adviser, Dr. David Johnson, who continually prompted me to work harder, write clearer, and think deeper about my work. 


\section{Acknowledgements}

It is important to thank a few people, without whose guidance this thesis would not have been possible. Each member of my committee was integral to the completion of this thesis. Dr. Gayle Thieman inspired me to want to pursue graduate work well before I began this program. Dr. Katy Barber not only helped me discover this topic during our graduate seminar class, but consistently encouraged me as I navigated the M.A. program. Dr. Ken Ruoff pointed me in so many new directions when it came to considering the study of historical memory, which has helped me both in this thesis and in my work teaching history education.

There have been many individuals who have supported my thesis project, from the staff and faculty at my home institution of Concordia University to the various academics and community members of Centralia. I am most grateful to Brian Mittge, my erstwhile companion in Centralia and later on Twitter, for his consistent support while writing this project. I also want to thank Tom Copeland, Susanne Weil, Bob Weyeneth, Anne Fischel, Eleanor Walden, Al Gunns, and Sandy Polishuk, who all gave freely of their time for interviews and conversations. Scott Daniels of the Oregon Historical Society deserves substantive applause for his consistent willingness to trek upstairs into archives to get the Ray Becker files. I appreciated every smirk on his face when I came through the elevator.

I also want to specifically thank the family of Lauren Banasky, with whose generous scholarship support I was able to travel throughout Washington in pursuit of various primary sources. I hope I honored Lauren's legacy through my dedication to this work. 
It is also important to me to thank my own students, whether they were at Jesuit or Gresham High School or at Concordia University, as their efforts continually inspired me to pursue my own aspiration of doing historical work.

Finally, special thanks to my wife, Cadie and my children, Griffyn, Fiona, and Norah, who consistently put up with my random train trips north, the hours spent in our backyard reviewing drafts, and the crankiness I surely expressed whenever I was reminded that it was time to take a break and eat dinner. 


\section{Table of Contents}

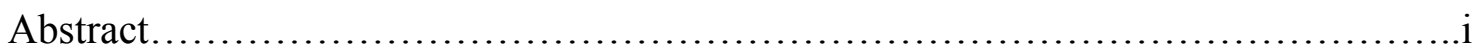

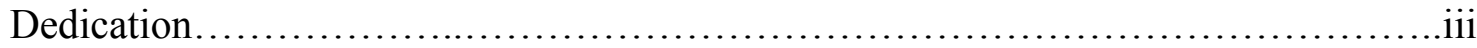

Acknowledgments.........................................................

List of

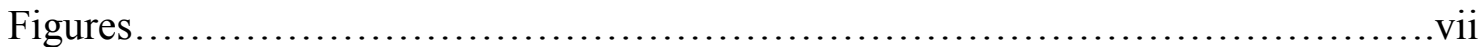

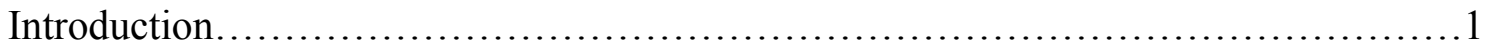

Chapter 1

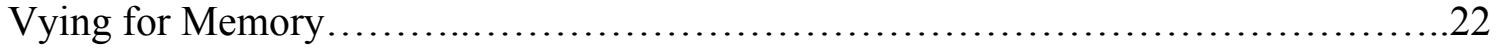

Chapter 2

"Authoritative" Accounts.........................................................59

Chapter 3

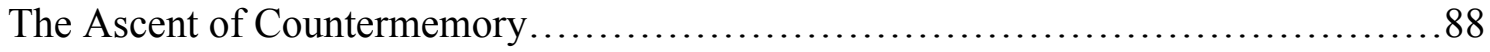

Epilogue

The Tragedy Memory...................................................121

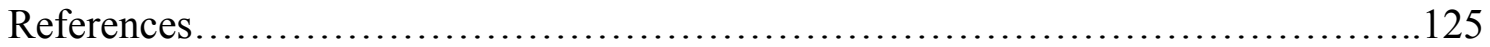




\section{List of Figures}

Fig. 1 Postcard of Wesley Everest........................................... 2

Fig. 2 Photo of Wesley Everest's burial......................................26

Fig. 3 Map of Massacre by Ben Hur Lampman.................................... 37

Fig. 4 Centralia Handbill....................................................... .44

Fig. 5 Sentinel Inscription.............................................. 48

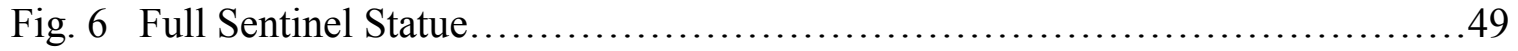

Fig. 7 Letter from Julia Ruuttila to Albert Gunns..............................67

Fig. 8 Program for the $60^{\text {th }}$ Anniversary Conference............................. 71

Fig. 9 Eleanor Walden Advertisement in the Industrial Worker..................... 74

Fig. 10 Selection from “A Wob Remembers" Proposal.............................76

Fig. 11 Photo from Centralia Tragedy Remembered textbook........................92

Fig. 12 Photo of Grave of Wesley Everest...................................96

Fig. 13 Photo of Cynder Viles's marker in George Washington Park.................99

Fig. 14 Mike Alewitz's Mural, “The Resurrection of Wesley Everest"................111

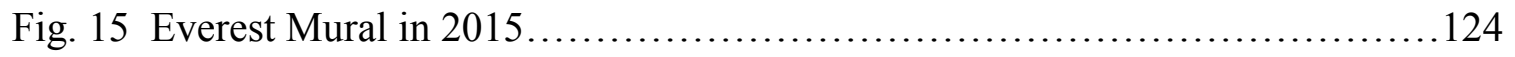


Introduction

"Everyone who has ever written or talked about it, in my opinion, had a different slant on the affair...",

Wesley Everest stood waist deep in the Skookumchuk River, pistol loaded and pointed at the encircling posse. Most of the uniformed men were hollering at him to surrender. He cursed himself for squandering his head start, for trying to wade across the frigid water when he couldn't swim. Breathless, he stared at his pursuers, many of them laughing at his predicament and howling about what they were going to do to him when he got back to shore. Scanning their faces, he detected a particularly smug expression sitting on one of the youngest guys there, neatly dressed and not in uniform. He looked a bit like F.B. Hubbard. They called for him to drop his weapon, although not a single rifle was trained on him. Everest considered his options, and then lifted his pistol toward the young man. Any smugness evaporated when he realized that Everest was about to unload the pistol.

Everest fired several shots, each one hitting its mark. The young man fell backwards as the other men were temporarily stunned. Everest turned to attempt to spread fire, but his gun jammed. He shook the handle to try to get it to work, but within seconds a rifle butt slammed into the side of his head, knocking him into the water. The men beat Everest thoroughly as they threw him on the shore. Those who tended to Hubbard tried to stanch his bleeding, but Everest knew his shots hit their mark and the boy would die. This was Everest's last thought before he lost consciousness as a knee landed right underneath his chin.

\footnotetext{
${ }^{1}$ Margaret Shields (Lewis County Museum staff), in discussion with author, October 2012.
} 


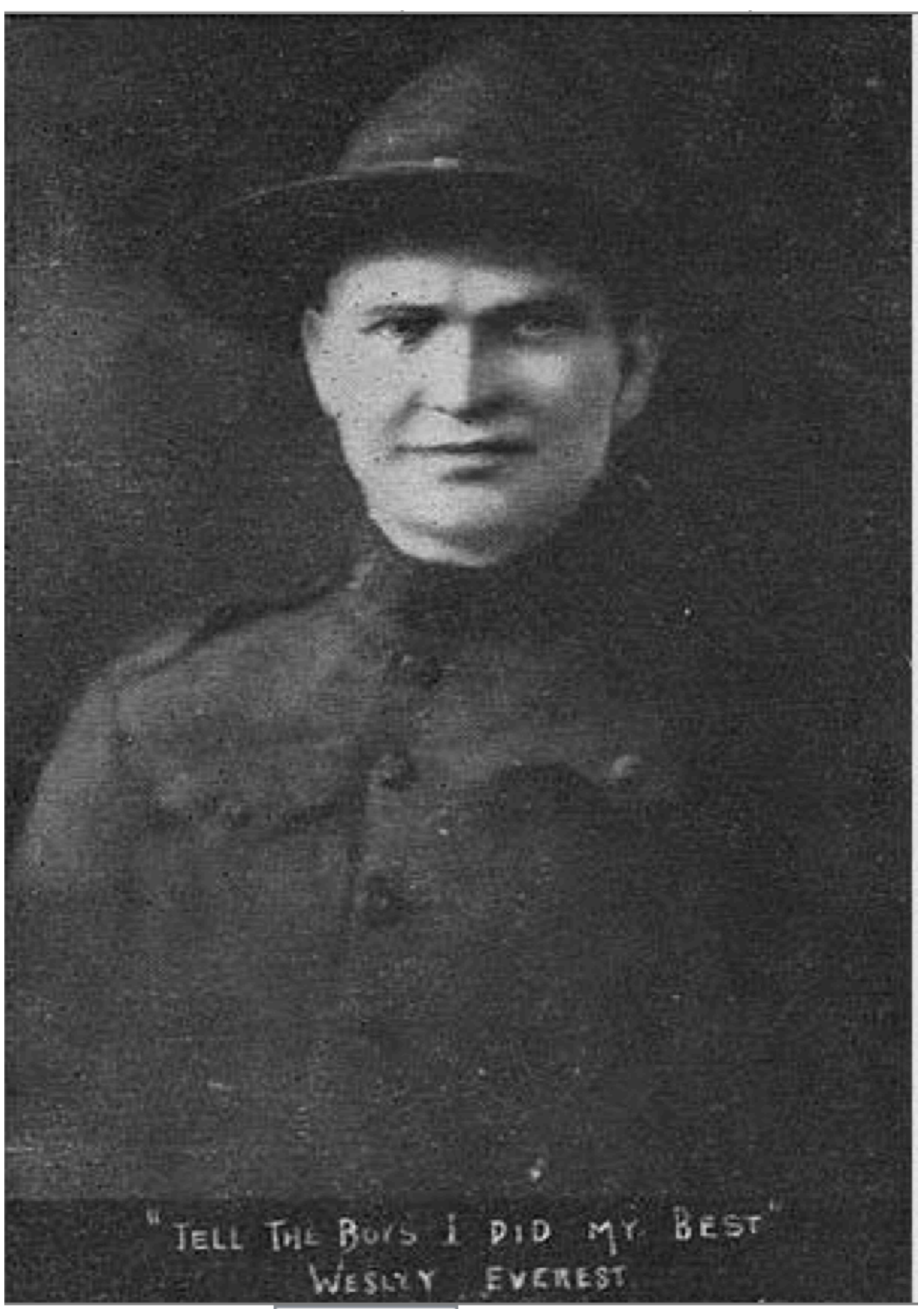

Fig. 1. Wesley Everest, postcard, ca. 1920, University of Washington I.W.W. digital collection, Centralia Massacre collection, http://digitalcollections.lib.washington.edu/cdm/singleitem/collection/iww/id /642/rec/1 (accessed July 1, 2015). 
Minutes earlier, Everest had been holed up in the Roderick Hotel in Centralia, Washington, alongside several of his fellow Wobblies. These Wobblies, or members of the International Workers of the World, a radical labor group that in Centralia consisted mainly of transient lumberjacks, opened fire on a parade of American Legionnaires who had been marching in the first ever Armistice Day parade on Tower Avenue in downtown Centralia. For weeks leading up to that November 11 march, the Wobblies had been hearing rumors of a raid on their hall, similar to a raid in April of 1918 that had evicted them from their previous meeting spot. Having been physically and verbally abused, and their belongings stolen and auctioned in the town that time, the Wobblies were intent on avoiding a recurrence. They appealed to the police in Centralia and printed a handbill asking for community support of their right to exist peacefully. When neither generated any reaction, they consulted with a sympathetic local attorney, Elmer Smith, who advised them that they had a natural right to defend themselves. So they planned a defense, gathering arms and placing members in the halls as well as surrounding hillsides and hotels, waiting for the Legionnaires, who were purportedly carrying out the raid, to make their move.

The parade commenced on November 11 with several detachments of the American Legion from throughout Lewis County, but the Grant Hodge Post of Centralia, led that day by lawyer and veteran Warren Grimm, a local hero who had been a standout football player at the University of Washington, eventually came to a halt right in front of the Roderick. In the ensuing moments, violence broke out between the Legionnaires and the Wobblies, although eyewitnesses and historians have long disagreed on what happened first - Did the Legionnaires storm the hall or the did Wobblies open fire? 
Within moments several Legionnaires were dead and the Wobblies were either trapped by the mob or fleeing into the surrounding wilderness. One of them, Everest, initially evaded capture, reportedly shooting dead one Legionnaire who blocked his way before stalling in the Skookumchuk because he couldn't swim.

The rest of the day consisted of Wobblies, real or suspected, being rounded up and brought to the Centralia jail. When Everest was apprehended, he was badly beaten and nearly lynched in Centralia Square before calmer heads brought him to the jail. Later that night, however, the power went off in Centralia, and a group of men seized Everest from the jail. They drove him to the Mellen Street Bridge and hung him off the side. The next day locals shot at his body with their rifles before the corpse was cut down, where it rested in the water below for the remainder of the day.

This incident triggered a series of anti-Wobbly crackdowns across the West Coast. The mainstream press like the Portland Oregonian and the New York Times were quick to report that the violence in Centralia was part of a nationwide scheme. ${ }^{2}$ This coincided nicely with plans from the Justice Department, which in this period, the first Red Scare, was looking for ways to stifle what they believed to be socialist sympathizers in the United States.

The national stakes led to a more than local interest in the ensuing trial. Eight of the Wobblies and the lawyer who advised them were tried for the murder of Grimm, who died in the gun battle. ${ }^{3}$ The trial had to be moved out of Lewis County, where Centralia

\footnotetext{
2 “Centralia Buries 2 of Heroic Dead.” Morning Oregonian, (Portland, OR), Nov. 15, 1919; "IWW Band routs Ex-Servicemen: Fighting Starts Near Centralia,” New York Times (New York, NY), Nov. 16, 1919. ${ }^{3}$ Kerry Irish, "Eternal Vengeance: A History of the Centralia Massacre," (master's thesis; University of Washington, 1989), 73; Ben Hur Lampman, Centralia Trial and Tragedy, (Centralia, WA: Grant Hodge American Legion Post, 1920), 70. As discussed in later chapters, the murder of Dale Hubbard, nephew of
} 
sits, to adjoining Gray's Harbor County. There in Montesano, the county seat, American Legionnaires and labor groups descended en masse. A team of prosecutors from across Washington represented the state, faced by "counsel of the damned" George Vanderveer, who had been retained by the national office of the I.W.W. The trial was not lacking for theatrics, nor was it immune to charges of impropriety. Half of the defense's original case was barred from presentation, when the presiding judge denied efforts to offer any context for the violence. The prosecution meanwhile was allowed to charge multiple defense witnesses with perjury moments after they left the stand. A detachment of soldiers appeared in Montesano the day the defense opened its case, out of fear of Wobbly sabotage. One Wobbly turned state's evidence to free himself, and another was presented as insane after he produced two confessions for the events of November 11. The trial even had multiple verdicts. Judge Wilson refused to accept the jury's first verdict and instructed them to try again. When they did, specifically requesting leniency for the Wobblies, Wilson ignored them and sentenced those convicted (seven in all) to the maximum possible sentence. ${ }^{4}$

Neither side was satisfied with the verdict. Both the American Legion and the Wobblies distributed pamphlets in the hopes of persuading Americans of the righteousness of their position, while the Legionnaires, who had presumably won the case, sought to sanctify the deaths of their four brothers. This movement first inspired talk of an American Legion museum in Centralia, although it gradually whittled down to the installment of a (still-standing) doughboy statue. The Wobbly pamphlets sought

F.B. Hubbard, was not included in the trial against the nine men. This was supposedly to leave it in reserve in the case that the trial for Grimm's murder did not return a guilty verdict.

${ }^{4}$ Lampman, 70 . 
redress and prompted a decade of organizing for justice. The Wobblies sent off to prison in Walla Walla became a national cause célèbre, and found themselves referenced in periodicals like McClure's and the novel 1919 by John Dos Passos. Although interest waned by the end of the 1920 s, there was still substantive press when the men were released, often one by one, in the early 1930s. The last to be released, Ray Becker, was feted by several labor groups for his devotion to the cause, even though Becker was flustered that after nearly 20 years of legal wrangling he did not receive the pardon he felt he deserved.

No one was ever brought to trial for the lynching of Wesley Everest, a sore point for the Wobblies and their sympathizers, who believed his extrajudicial death merited some form of investigation. This, in addition to what many felt was a miscarriage of justice in the Montesano courtroom, prompted an ongoing revision of the memory of what I refer to as the Centralia Tragedy well into the present. ${ }^{5}$

\section{Commemoration}

In November of 2009 the Centralia community gathered to observe the ninetieth anniversary of the Tragedy. The 2009 remembrance centered mainly on what happened to Everest. Sponsored by the Evergreen State College (Olympia, Washington) Labor Center, the festivities ranged from a screening of Evergreen media professor Anne Fischel's Lewis County: Hope and Struggle, a film chronicling the efforts to make a mural of Everest overlooking the city's Washington Park, to a performance, "The

\footnotetext{
${ }^{5}$ By choosing to call this event the "Centralia Tragedy" the author is making a conscious decision with regards to his own perspective. Use of the term "Centralia Massacre" is often associated with those individuals affiliated with the Wobblies. "Armistice Day Riot" sometimes gets associated with those connected to the Legionnaire perspective. A succinct conversation about terms associated with this event is included in Robert Weyeneth, "History, He Wrote: Murder, Politics, and the Challenges of Public History in a Community with a Secret," Public Historian 16, no. 2 (1994): 66.
} 
Centralia Tragedy through Music and Song,” two nights later at Centralia's Corbet Theater. A walking tour, a panel discussion by present-day I.W.W. workers, and an academic Lyceum involving labor historians and an American Legion chaplain at nearby Centralia College all contributed to the conversation, which the local paper, the Centralia Chronicle, covered extensively. The head of the Labor Center, Peter Kardas, was quoted as saying that this may have been the first time the anniversary was commemorated. $\mathrm{He}$ later corrected himself, noting "this is the first time, in quite a while, at least."

It was a good catch by Kardas, because various groups had commemorated the Armistice Day events for nearly forty years. What Kardas may have been thinking, however, was that such an open commemoration of this narrative of the Tragedy, sympathetic to the Wobblies, had not occurred as often. To be more precise, Kardas's Labor perspective had been celebrated publically more than a few times in the previous decade, notably with the 1997 unveiling of "The Resurrection of Wesley Everest" mural in Centralia Square. Yet, Kardas was right to indicate that these types of commemoration had not the norm over the past ninety years. Moreover, he and the organizers of the Lyceum were concerned about just how the greater Centralia community would react. ${ }^{7}$

But why would a commemoration like this, ninety years after the event, be cause for any concern in the community? From an outsiders' perspective, the organizers seemed to have covered all of the bases -they invited speakers from all vantage points to participate. Yet, whenever an event like this happens in Centralia, there is a pervasive sense of anxiety. That trepidation resurfaced again four years later when Marshall Murray organized a birthday party commemoration for Elmer Smith, and it appears to

\footnotetext{
6 "Truth of the Tragedy," Centralia Chronicle, (Centralia, WA), Nov. 10, 2009.

${ }^{7}$ Susanne Weil (Centralia College English professor), in discussion with author, October 15, 2012.
} 
this day when talking to citizens on the streets of Centralia. ${ }^{8}$ Those with no personal connection to the Tragedy itself observe that it is an event that still is not settled. ${ }^{9}$

But why? Why has this event garnered such a response that even citizens with no personal connection express a tangible concern about discussing it openly? Why is there open hostility to the various memories that exist, particularly when those memories recall an event that no one experienced first hand? This thesis attempts to understand that dilemma, by looking at how the community of Centralia has remembered the Tragedy over the course of almost a century, and the hostility between various frameworks of memory. It considers the trauma that was inflicted on Centralia in 1919, and how angst has proliferated into the present through the conflicting strands of memory held inside and outside of Centralia, compounded by the efforts to accurately assert the "truth" of the Tragedy, when realistically the eternal existence of multiple truths is likely to persist.

This thesis examines this strife in remembering and what has sustained it over the past one hundred years. This is a new approach to the Centralia Tragedy, as I am less concerned with the events of November 11, which have been comprehensively dissected by participants, lawyers, activists, historians, novelists, and teachers. While my interest was initially piqued by the treatment the Wobblies received, as well as the inability of the community to address the brutal lynching carried out by their town's leadership, I am content to leave that discussion aside. This thesis looks instead at the story of the Tragedy, as woven by multiple narrators across several generations, and how each of those narrations has colored the collective memory of the event.

\footnotetext{
${ }^{8}$ Marshall Murray (Centralia resident), in discussion with author, July 26, 2014.

${ }^{9}$ Rebecca Staebhler (Centralia business owner), in discussion with author, July 26, 2014.
} 
I find that story and its impact on Centralia significant considering the relatively small-scale of the violence. With respect to the suffering of the individuals and families involved, it strikes me as peculiar that the memories of this singular day continued to challenge a community so long into the future, and that varied groups, for their own purposes at various points in Centralia's history, have used it as a rallying point. Considering the extensive attempts to chronicle the Tragedy over the years, the fact that the local narratives have not been mapped out can be illuminating for all. It may be particularly valuable for scholars of small communities and collective memory elsewhere.

\section{Considering the Collective Memory of Centralia}

To understand what transpired over the century in Centralia, we have to have an operational understanding of the process of collective memory, as well as the ways in which scholars have contributed to its evolution. The origins of modern collective memory studies are often traced to French sociologist Maurice Halbwachs's 1925 work Social Frameworks of Memory, and a posthumous compilation of his essays, The Collective Memory. Halbwachs's contention was that everyone's past is composed of two separate strands - one that could be readily evoked in our thoughts and another that was more challenging to extract. The former, he posited, was easier to access because it was stored in the collective, or within those that were around us (family, friends) that provide consistent reminders of those memories or who may have shared the same experience. The recollections that are most difficult to reach, according to Halbwachs, were those we experienced on our own, and therefore could often only be summoned by chance, such as 
when we picked up a scent that stirred the memory. Halbwachs, therefore, articulated that individual memory existed within necessary social frameworks. ${ }^{10}$

Since then, studies of collective memory proliferated, influenced by Halbwachs but moving in several directions, with a notable "boom" of scholarship in the late 1980s and 1990s when several influential works emerged. One of the most prominent was Henry Rousso's The Vichy Syndrome, which depicted collective memory as something that can evolve both slowly and rapidly, based on various communal flashpoints. Rousso examined the ways in which the French community "remembered" the crimes of the Vichy collaborators, and carefully mapped when "flare-ups" of memory occurred. Tying back to Halbwachs, these "flare-ups" were when French society began to frequently discuss its shared experiences, so that the memories were constantly aired. Rousso also plotted the means by which a nation shaped its collective memory - so he detailed the "vectors," or carriers, such as popular cinema, schoolteachers, or public commemorations that caused alterations in those joint memories. Rousso's vector terminology - official, organizational, cultural, and academic - will be utilized in this work, as I use his concepts to categorize the frameworks of memory of Centralians. ${ }^{11}$

Israeli historian Yael Zerubavel had explained this development more clearly a few years earlier with what she termed "countermemory." To Zerubavel, this is "the alternative commemorative narrative that directly opposes the master commemorative

\footnotetext{
${ }^{10}$ Maurice Halbwachs, The Collective Memory. Translated by Francis J. Ditter and Vida Yazdi Ditter. (New York, NY: Harpers Row, 1980), 45-49, 80-87, 124-127 in Jeffrey K. Ozick, Vered Vitnitzky-Seroussi, and Daniel Levy, The Collective Memory Reader (Oxford: Oxford University Press, 2011) 140-142.; Jeffrey Ozick, Vered Vitnitzky-Seroussi and Daniel Levy. The Collective Memory Reader. (Oxford: Oxford University Press, 2011), 18-19.

${ }^{11}$ Henry Rousso, The Vichy Syndrome: History and Memory in France since 1944. (Cambridge, MA: Harvard University Press, 1991), 220-225.
} 
narrative, operating under and against its hegemony." ${ }^{\prime 2}$ In her work, Recovered Roots, Zerubavel examines the shaping of collective memories as part of the creation of nationalist narratives. This mythologizing has a longer history in scholarship, and has been referenced by historians of memory like Benedict Anderson in Imagined Communities and Eric Hobshawn in The Invention of Tradition. Yet, Zerubavel devotes significant time to the construction of countermemory, discussing its role denying "the validity of the narrative constructed by the collective memory," particularly if that collective memory had attempted "to suppress alternative views of the past."13 She further explained that countermemory was frequently used by groups who were marginalized by society, and its interaction with the official collective memory made the "commemoration of the past a contested territory.",14

Zerubavel also identified the friction between collective memory and countermemory in contemporary political spaces, isolating her own hot spots where minority groups were suppressed from commemorating events because of the potency of the "subversive character of countermemory." She reviewed the ongoing conflicts between the Native Americans' perspective of the American historical narrative (in her case, the Thanksgiving debate) and the traditional American portrayal. This Native American challenge to the master commemorative narrative has arisen countless times in American history, most recently in Ari Kelman's Bancroft prize-winning book, $A$ Misplaced Massacre, about the collective memory and countermemory of the Sand Creek Massacre. Zerubavel's claim, that these assertions of countermemory are trying to require

\footnotetext{
${ }^{12}$ Yael Zerubavel. Recovered Roots: Collective Memory and the Making of Israeli National Tradition. (Chicago, IL: University of Chicago Press, 1995), 10-11.

${ }^{13}$ Ibid.

${ }^{14}$ Ibid.
} 
"the redefinition of...collective identity" to assert a "marginalized group's claim for greater representation" is important to the development of Centralia labor narratives that demanded consideration and ultimately won it. ${ }^{15}$

Zerubavel also related several instances where people "compartmentalize knowledge" so well that oppositional "history and memory can coexist without any apparent friction." ${ }^{16}$ In this case, Zerubavel noted that even with clear evidence that the Israeli leadership distorted certain memories, such as the legends behind the Tel Hal skirmish of 1920, people still accepted them. Zerubavel theorized that the many ways that the Israelis had been subjected to this debate on history and memory, and their tangential knowledge that scholarly work was appropriated for use with the master commemorative narrative, influenced their unwillingness to accept the "historical" record" alone. ${ }^{17}$ This phenomenon - a collective understanding that defies what is perceived by scholars as historical record - is evident within Centralia, particularly in the appropriation of the Wesley Everest story by the Labor movement in the beginning of the twenty-first century.

Historian Pierre Nora noted the impact of the upswing of memory studies, claiming that the focus on memory in some instances cleaved control of history away from the academic sphere. He saw the rise of public commemorations, particularly when aligned with commercial or tourist operations, as seizing the opportunity for average individuals to control their history. We will see a specific split along these lines in terms of controlling the Tragedy narrative, particularly the wrestling between the Labor

\footnotetext{
${ }^{15}$ Ibid., 11.

${ }^{16}$ Ibid., 234-235

${ }^{17}$ Ibid., 214-237.
} 
community and academic community, which in this thesis is a third alternate framework that few within the Centralia community have accepted. More importantly is Nora's observation, somewhat like Zerubavel, that memory is "bound up with minority groups for whom rehabilitating their past is part and parcel of reaffirming their identity." 18 As this thesis examines the public history acrimony between 1993 and 2009, it discusses how a group of Wobbly-sympathetic citizens have used this "moment" to recast the story of the Centralia Tragedy as an empowering parable.

Past scholars of memory, such as W. Lloyd Warner, have studied small town experiences, and others have examined societal response to large-scale traumas. Few works, however, have examined the impact of local traumas on small communities. ${ }^{19}$ Because of the tight-knit nature of these smaller communities, and the natural divisiveness of both classism and violence, the weight of these tragedies may be greater than what has been thought. This study contributes to scholarship through a focus on that nexus. Furthermore it responds to a call from Sam Wineburg, a scholar of history education, to examine the collective memory of "ordinary people" whom historians of collective memory have neglected. ${ }^{20}$ I hope that students of collective memory, as well as those who teach history, will find instructive and illuminating the way in which the shifting narratives of this singular event have impacted Centralia.

\section{The Path of Memory}

\footnotetext{
${ }^{18}$ Pierre Nora, "Reasons for the Current Upsurge in Memory." Transit 22, 1-8 (2002): 1, 4-8, in Jeffrey K. Ozick, Vered Vitnitzky-Seroussi, and Daniel Levy, The Collective Memory Reader (Oxford: Oxford University Press, 2011), 439.

${ }^{19}$ W. Lloyd Warner, The Living and the Dead: A Study of the Symbolic Life of Americans. (New Haven, CT: Yale Historical Press, 1959).

${ }^{20}$ Sam Wineburg, Historical Thinking and Other Unnatural Acts. (Philadelphia, PA: Temple University Press, 2001) 242-250.
} 
The first chapter of this thesis, "Vying for Memory," analyzes the period of immediate memory framework formation, which stretches from the day after the Tragedy to the early 1960s. Directly following the event, various groups attempted to shape the collective memory. Pamphlets from national branches of the I.W.W. and the American Legion were heavily circulated throughout Washington, the most notable being "The Centralia Conspiracy," written by Wobbly author Ralph Chaplin, and "Centralia: Trial and Tragedy," penned by Oregonian reporter Ben Hur Lampman under commission of the American Legion. A third major pamphlet, "Was it Murder?" by labor sympathizer Walker C. Smith, followed. Together all three perspectives shaped public discourse about the event both in Centralia and the region.

Those who believed Lampman and the Legionnaires' take soon furthered their claim on collective memory by erecting, in 1924, "The Sentinel," a statue in Centralia's Washington Park. This bronze statue, a life-sized depiction of a doughboy soldier on watch, has been the symbol of master commemorative narrative of the Tragedy. It embodies the pro-Legionnaire position. I have dubbed this narrative "the official framework," borrowing from Rousso's terminology. The Sentinel is thus emblematic of all those who serve as carriers of this framework. Its dedication to the four slain Legionnaires followed suit: "Slain on the streets of Centralia, Washington Armistice Day Nov 11, 1919 while on peaceful parade wearing the uniform of the country they loyally and faithfully served." The Legionnaire narrative was clear - the sacrifice of those four Centralians was equal to that of any who died in combat overseas. As long as the Sentinel stood uncontested, the official framework of the Tragedy, the Legionnaires' perspective, had held firm with Centralians. 
But even with such a public statement of Legionnaire support, the battle for memory was not going to be easy on the townsfolk. Appeals were filed on behalf of the convicted Wobblies almost immediately, and residents were asked to submit affidavits by the Wobblies' legal team. ${ }^{21}$ Ongoing efforts by Elmer Smith, who was not convicted in the Montesano trial, kept the Wobblies' situation in the public eye. Smith toured the state to deliver orations about the Tragedy and trial, spreading the pro-Labor narrative nationwide. While this didn't necessarily translate to their release, it planted and sustained a narrative that convinced people like activist Julia Ruuttila to pick up Smith's mantle when he died. When Becker refused to accept a sentence commutation, vowing to remain in prison until he received a pardon clearing him of any wrongdoing, Ruuttila proved to be the agent that sustained his efforts.

Ruuttila's work is even more important for this study. In many respects, she served as one of the originators of the countermemory of Centralia, which I term the "Labor countermemory framework," borrowing from Zerubavel. Ruuttila sustained the pro-Labor narrative through her frequent writings in the Labor Press and her curation of papers related to the Free Ray Becker Committee she led. This collection, which today sits in the Oregon Historical Society, is an eclectic mix of materials that paint a very different picture than the Sentinel. As Ruuttila attempted to find people to speak for Becker, she confronted citizens unwilling to revisit the details of the massacre, creating a clash between the two frameworks of collective memory and countermemory. After

\footnotetext{
${ }^{21}$ Walker C. Smith, Was it Murder? (Seattle, WA: Northwest District Defense Committee, 1922), 8. Prompted by the fact that many jurors said, after the trial, that they felt undue pressure to convict the defendants, even though they had doubts about the case presented by the state. This will be discussed in chapter one when discussing juror experiences.
} 
Ruuttila initially left Centralia for other work in the late 1930s, community members occluded her cultural framework for nearly 25 years.

Chapter one also looks at the failure of what historians refer to as "The Church Report," authored by theologian DeWitte Wyckoff in 1930. This report, commissioned by a cooperative of Washington church groups, was arguably the first academic publication to address the Tragedy. Its proximity to the event, along with Wyckoff's methodology and conclusions, make it a compelling read, particularly in its call for the community to consider shared responsibility for the Tragedy. Maybe unsurprisingly, many locals in Centralia dismissed Wyckoff, even though it offered a blueprint for reconciliation. This rejection of the academic perspective, by adherents of the two other frameworks, will be a consistent trope in this chronicle of Tragedy memory. I also believe it means that the academic framework has not been effectively coopted by either (although both have tried). That is, it stands as a third, separate framework to understand the Tragedy.

The second chapter, "Authoritative Accounts" examines Centralia's understanding of the 1919 Tragedy as it experienced a dramatic upturn in attention between 1964 and 1989. In these years, the Centralia Chronicle, regional historians and community members attempted to address the events. These efforts would culminate in the book Wobbly War, by journalist John McClelland, considered by many to be the comprehensive treatment and often categorized as "even-handed" by locals. ${ }^{22}$

Reengagement in the 1960s-1980s with the history and memory of Centralia sprouted from the Centralia Chronicle, which in the 1920s had served as a primary agent

\footnotetext{
${ }^{22}$ Margaret Shields (Lewis County Museum staff), discussion with author, October 2012.
} 
of the official framework. In the early 1960s a Seattle Post-Intelligencer article appeared about the Tragedy, casting citizens of Centralia in what the Chronicle felt was an unflattering light. In response to this, the paper felt compelled to review the official framework, in order to set the record straight. Over the next several years, the Chronicle released sporadic articles that began to bring the Tragedy back into public conversation.

While academics included Centralia in their work as early as 1954, relevant articles weren't published until the late 1960s. Historian Albert Gunns crafted a piece about Ray Becker that appeared in the Pacific Northwest Quarterly in $1968{ }^{23}$ This offered greater insight into the period following the trial of the Wobblies, although to the consternation of Ruuttila, whose document collections aided Gunns, it did not argue for change in how the event was perceived. It is here we see the attempt by the Labor countermemory framework to coopt the academic framework, which ultimately failed. The interaction between Gunns and Ruuttila is treated in this chapter, as I believe it further illuminates the division between the academic framework of the Tragedy and the Labor countermemory framework that Ruuttila transmitted. The friction between the two, sustained more by Ruuttila, continued for nearly 20 years, climaxing in a testy exchange at a meeting of the Pacific Northwest History Association in $1979 .^{24}$

Others working in academe eventually aided the development of both official and Labor frameworks. First came Lawrence Skoog, who investigated affidavits drafted after the trial and argued that they had historical weight as the voice of the people of Centralia. His master's thesis and a short article in the Oregon Historical Quarterly argued that

\footnotetext{
${ }^{23}$ Albert Gunns, "Ray Becker, the Last Centralia Prisoner," Pacific Northwest Quarterly 59, no. 2, (1968).

${ }^{24}$ John McClelland, Wobbly War: The Centralia Story. (Tacoma, WA: Washington State Historical Society Press, 1987), 238.
} 
scholars should examine those voices to understand the Tragedy. ${ }^{25}$ Another graduate student, Eleanor Walden, did much the same in the late 1970s as she plotted a documentary as part of a University of California master's degree project in Folklore studies. ${ }^{26}$ Her completed oral histories, now on file at the Kirk Library in Centralia, are fairly extensive, containing the rich recollections of many elderly Centralians who had experienced the fallout from the Tragedy. Both Skoog and Walden lent a measure of academic support to Ruuttila's position, even though neither produced substantive academic historical work.

In the late 1980s, John McClelland finished his book, Wobbly War. His treatment is fraught with issues - ranging from his journalistic impulses, which somewhat prevent this work from being seen as fully academic, to his contention that the Tragedy story itself was considered a "secret," which is simply false. ${ }^{27}$ Nonetheless, many locals refer to the text as the definitive account of the Tragedy, which is revealing. Unlike Wyckoff or Gunns, McClelland didn’t present an interpretative challenge to Centralians who maintained the official framework of memory, and this made the book a prime target to be coopted for that perspective.

The third chapter, "The Ascent of Countermemory," reviews several notable moments between 1990 and 2009 where the various frameworks came into direct conflict with one another. The carriers of the Labor countermemory framework prompted most of these conflicts, although an academic, Robert Weyeneth, orchestrated the initial one.

\footnotetext{
${ }^{25}$ Lawrence Skoog, “Labor Violence: The Centralia Case, The I.W.W., and its Enemies,” (master's thesis, Portland State University, 1975).

${ }^{26}$ Eleanor Walden, “A Wob Remembers,” Eleanor Walden Papers, Centralia College Kirk Library, Box 5.3 .

${ }^{27}$ McClelland., xiii.
} 
Weyeneth, a professor of public history at the University of South Carolina, produced the last notable academic work on Centralia. ${ }^{28} \mathrm{He}$ had recollected his efforts to place both the Sentinel and the grave of Wesley Everest on the National Register of Historic Places. Weyeneth argued that the issue for many Centralians was unsettled, although by the early 1990s the time was ripe for reconciliation because of local actions, such as the creation of a school textbook. Even as he succeeded in getting sites on the National Register, Centralians generally ignored his efforts. His experience reflects the general dismissal of the academic framework by the other strands of memory.

Weyeneth's effort was followed, by the work of a high school student, Cynder Viles, which exploded into controversy. Viles became embroiled in a major commemorative dispute in the city after she won a statewide history competition with an entry about the Tragedy. The Viles episode is a tipping point in which the official collective memory framework of Centralia gave way to the Labor countermemory in terms of commemorative heft. It is during her encounters with the community - from the town council to the Chronicle to the average citizen who was following the debates - that we see the collision of the vectors, with even the academic framework entering the fracas. If some type of reconciliation between the frameworks was possible, the Viles controversy was the time it was most likely to have been successful. Yet Centralians missed that opportunity, and instead the fracture between the frameworks remained.

Chapter three continues to highlight the various tracks that the frameworks took after the Viles controversy. It emphasizes the decline of the official framework and the quieting of the academic since 1997, and details the way in which the Labor

\footnotetext{
${ }^{28}$ Robert Weyeneth, "History, He Wrote: Murder, Politics, and the Challenges of Public History in a Community with a Secret," Public Historian 16, no. 2 (1994).
} 
countermemory framework came to dominate discussion of the Tragedy. Just four years after the Viles episode, the owner of the Centralia Antiques Market, which sat directly next to Washington Park, commissioned an artist, Mike Alewitz, to design a mural to overlook the Sentinel statue. This mural, "The Resurrection of Wesley Everest," depicted Everest as risen Jesus, arms outstretched in front of a sunburst, along with several Labor-related montages. Its creation and placement were controversial, earning condemnation from the national convention of the American Legion. Yet the Legion backed off after that first show of resolve, allowing the unveiling ceremony to commence without incident, a telling response by the carriers of the official framework. This resurrection was thus symbolic on another level - with the mural the Labor countermemory framework, dating all the way back to Ralph Chaplin, was reborn.

Simultaneously the Chronicle, previously an official framework standard-bearer, changed course. In 2001 it published a five-day feature on the Tragedy, extending the conversation of the event to include its impact on the modern labor movement. This was a significant shift for the paper, and highlights the way in which the Labor countermemory framework of Centralia had once more made headway in shaping the depiction. A documentary by Anne Fischel that followed several community members as they assembled the Everest mural furthered that framework. Fischel presented the Tragedy story from the Labor vantage point, almost entirely disregarding the official and academic frameworks of the event.

By 2009, therefore, Labor countermemory carriers of the Tragedy memory, having fought successive battles in Centralia saw their efforts paying dividends in the 
story's transmission. The conversation in the news, at the college, and in the community was becoming decidedly pro-Labor, a significant reversal from forty years prior.

Ultimately this thesis examines that transformation of the Centralia Tragedy from its original collective memory to its counter memory. Relying on archival materials letters, local papers, educational materials and the oral histories of both living and deceased residents, it investigates how a small town remembered its most notorious moment, and how that collective memory shifted over the course of ninety years. The aim is a comprehensive explanation on the region's understanding of the Tragedy. To do that, we begin with the initial battle for public sentiment in the 1920s and 1930s. 


\section{Chapter 1: Vying for Memory}

Wesley Everest, beaten savagely by an infuriated mob after being dragged back from the Skookumchuk River, was still lying in the Centralia jail, teeth smashed and bleeding. In the early hours of the evening, after the city electrician had left for the evening, the power in all of Centralia was cut, casting the city into darkness. This darkness was deliberate; a man who flipped on his car's headlights had them both smashed immediately. ${ }^{1}$

While the events of the day were certainly tragic, the battle for the collective memory of the Centralia Tragedy might never had happened had this night passed uneventfully. Yes, there had been the violence during the raid on the Wobbly hall during the Armistice Day parade. Four Centralia Legionnaires, Warren Grimm, Ben Cassagranda, Alfred McElfresh and Dale Hubbard had been killed in the process, while several others were wounded and in critical condition. But the majority of the Wobbly resisters had been apprehended, including Everest, who had killed Hubbard on the riverbank. Had nothing else followed, and had law enforcement and local leadership stopped what transpired that evening, the story of the Centralia Tragedy probably would have ended after the Wobby trial in 1920.

As it were, once the lights went out, a group of local vigilantes, which scattered reports, affidavits and oral testimonies claimed consisted of city leaders like county coroner David Livingstone and future mayor Howard Barner, pounded on the doors of

\footnotetext{
${ }^{1}$ Ralph Chaplin, The Centralia Conspiracy (1920; reprint, Teddington, England: The Echo Library, 2007), 67.
} 
the jail. ${ }^{2}$ Historians claim the crowd actually asked for Britt Smith, the local IWW Secretary and steward of the Wobbly Hall. While they wanted the man who had been burst from the Wobbly Hall attempting to evade capture (Everest), they never checked his name. Even with that request for Smith, however, the group eventually left with the man the town had already beaten up earlier in the day. ${ }^{3}$

Conflicting accounts of the evening have cast doubt on what actually transpired although they include similar details. Everest was dragged out of the jail and into one car in a small motorcade, thrown into the backseat with Livingstone. The motorcade left the jail and headed for the Chehalis River Bridge. Some accounts, including the earliest one written by I.W.W. writer Ralph Chaplin, include a sequence where Livingstone, a doctor, castrated Everest's in the backseat of the car. ${ }^{4}$ Once the group arrived at the bridge, the vigilantes beat Everest, put a noose around his neck, and flung him off the bridge, twice. Wobbly versions categorized the second throw as sheer cruelty, but more contemporary descriptions believe that this was because the first rope was too short and didn't snap Everest's neck. ${ }^{5}$

Everest's body was left dangling so that by morning he was visible above the river. After the hanging, locals fired rifle shots at Everest's corpse, until someone cut the rope and the body fell to the riverbank. Livingstone later returned for it, taking it back to

\footnotetext{
2 “Prosecution and Defense Witness Lists - List of Suspected Lynchers," Ray Becker papers, Mss 2003, Folder 1/28, Oregon Historical Society.

${ }^{3}$ Kerry Irish, "Eternal Vengeance: A History of the Centralia Massacre" (master's thesis, University of Washington, 1989), 113.

${ }^{4}$ Chaplin, 67-70. This particular event is subject to significant debate, even to the point that later authors have argued its veracity. Two of the more prominent works on the Tragedy, by Tom Copeland and John McClelland, take opposing perspectives on whether this happened. Irish agreed with Copeland, adding to Copeland's argument that news of the castration never surfaced at the trial at Montesano, and was only offered to the public after the verdict. Later Labor advocates ignore this debate entirely.

${ }^{5}$ Tom Copeland, "Wesley Everest: I.W.W. Martyr." Pacific Northwest Quarterly, 77, no. 4 (1986): 125.
} 
the Centralia City Jail and throwing it where the vigilante group had initially found it, to the abject horror of the other Wobblies still in their cells. The city left Everest's decaying body "in state" at the jail for the next two days.

\section{The Impact of a Body}

Authors like Chaplin and fellow Wobbly Walker C. Smith contended that the presence of Everest's remains made a significant impact on the emotional and mental state of the Wobblies imprisoned in Centralia. ${ }^{6}$ While official word was that no undertaker was willing to bury the corpse, Chaplin and Smith argued that Livingstone, who had left Centralia for Portland and did not complete his role as coroner in the formal county inquest for the slain Legionnaires, left Everest's body in the jail to convince the Wobblies to turn on each other. This, combined with several other persuasive techniques - "third degree" questioning, letting a mob encircle the prison chanting for the Wobblies, rifle barrels pointed into cells at the accused -- may have had that effect. ${ }^{7}$ Several of the prisoners reputedly believed that at any point they would be seized from the jail like Everest. The strain caused two of them to crack.

The first was Tom Morgan, who is frequently referred to in the Wobbly literature only by the moniker of "stool pigeon." "Morgan was one of the younger Wobblies under arrest, and the most visibly disturbed by Everest's body. He quickly agreed to turn state's evidence against the other Wobblies. More dramatic was the impact the body had on Loren Roberts, declared insane during the ensuing trial. Like Morgan, Roberts broke

\footnotetext{
${ }^{6}$ Chaplin, 68; Walker C. Smith, Was it Murder? (Seattle, WA: Northwest District Defense Committee, 1922), 42.

${ }^{7}$ Chaplin, 68-69; Smith, 41-42. Many of the prisoners recalled that they could barely get a few hours of sleep in the time that they were in the Centralia jail. Prisoner Mike Sheehan attributed this to the noise but also the cold, as they were not given blankets while imprisoned during the early winter.

${ }^{8}$ Smith, 41.
} 
down in the jail and signed two confessions as to his role in the Tragedy. Yet unlike Morgan, the defense ultimately argued that Roberts, by virtue of his insanity, could not be held to his confession. Intriguingly, various interpretations of the events describe how Roberts was before and after his imprisonment, and while nothing conclusively says he was perfectly fine prior to the jail, a contemporary observer might argue that whatever issues he might have had were magnified by the stint. ${ }^{9}$

This is not to say that Centralia is unique in that law enforcement used harsh tactics to wring confessions from the accused. In trying to understand the ways in which the collective memory of the tragedy splintered, however, the treatment of the Wobblies and their confessions under duress, effective in the short run for securing a conviction, complicated the understanding of what actually transpired on the day itself.

After two days an undertaker still had not removed Everest's body. In response, the jailors took a separate group of prisoners, those rounded up as suspected Wobblies, along with the body on a long drive. According to an affidavit filed by one of them, Simon Hill, the men were put into a car and driven for about a half hour from the city jail. Later, when the city claimed that Everest was interred at the far edge of Sticklin cemetery, Hill disagreed. He believed that the car trip to bury Everest took far longer than it would normally take to reach that spot in Sticklin. ${ }^{10}$

\footnotetext{
${ }^{9}$ Ben Hur Lampman, Centralia Trial and Tragedy (Centralia, WA: Grant Hodge American Legion Post, 1920), 42-43. In Lampman's account, which is notably anti-Wobbly, Lampman insists that Roberts' sanity was merely a ruse of the defense used to discredit the secured confession. This may have still been the case, but in the late 1920s fellow Wobbly Ray Becker, imprisoned with Roberts, nevertheless commented on how the ordeal ultimately affected Roberts' sanity in a private letter to Julia Godman Ruuttila, which is in folder 1/1 of the Ray Becker Collection at the Oregon Historical Society Mss. 2003.

10 “Simon Hill Affidavit, 1936 taken by Julia Godman.” Ray Becker papers, Mss 2003, Folder 2/5, Oregon Historical Society Research Library. In visiting Centralia you can find "the grave" of Wesley Everest. It sits at the extreme end of Sticklin Cemetery, somewhat away from the other plots. Articles have also been written about its location, most notably Robert Weyeneth, "History, He Wrote: Murder, Politics, and the
} 


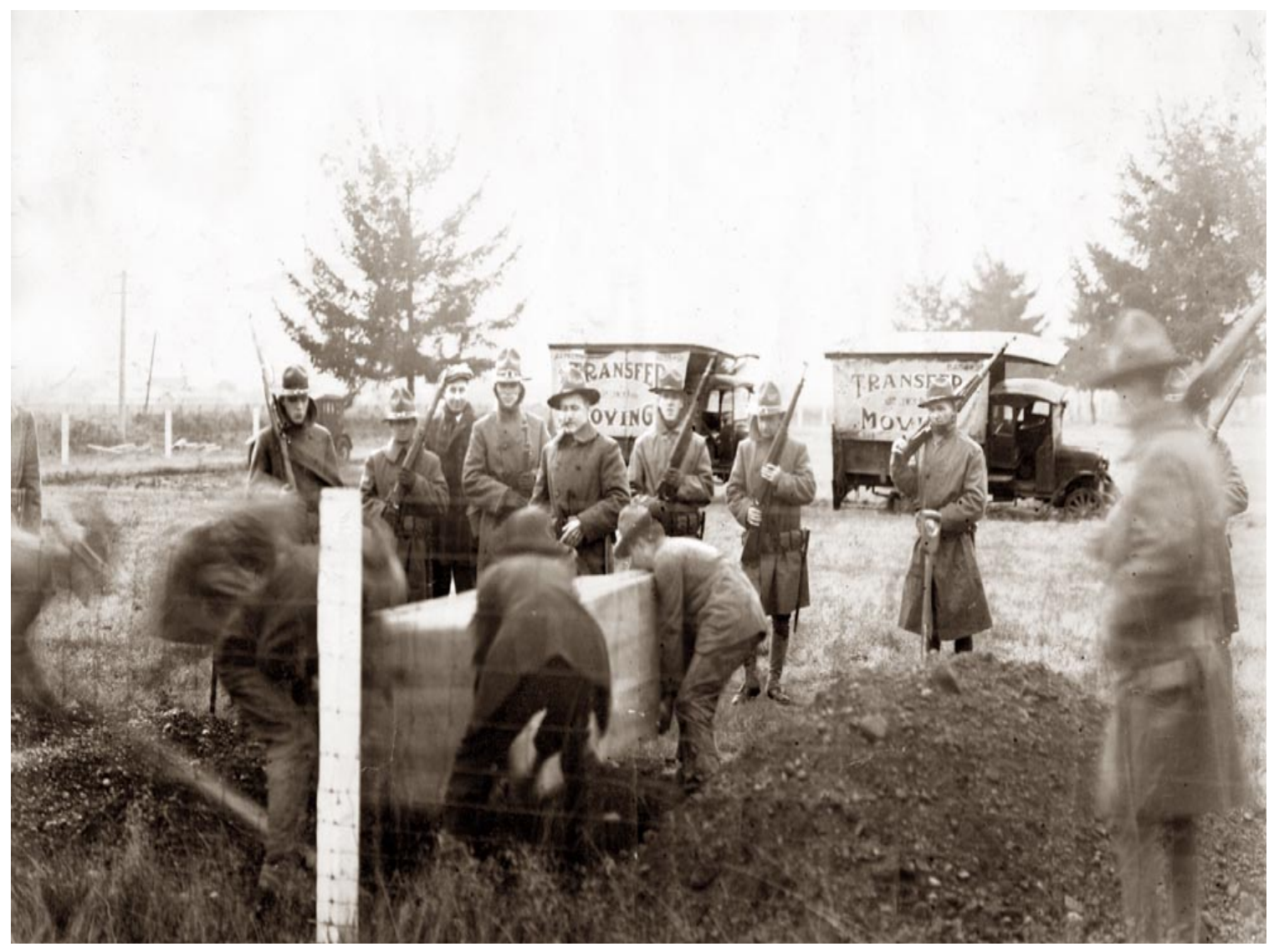

Fig. 2. Wesley Everest being buried, 1919, photo, Ancestry.com website, http://freepages.genealogy.rootsweb.ancestry.com/ cainhome/remmen album/emil_guar d/centralia_tragedy.htm (accessed on May 12, 2015). ${ }^{\overline{1}}$

Without an actual body it would be impossible to try any citizen for its destruction. No one has ever been tried for Everest's death, and the claim that Everest's body was hidden gave pro-Labor adherents opportunity to argue about its treatment. Later descriptions of the body as castrated circulated without proof. While those who obscured the grave probably did so to eliminate it as a rallying point for Northwest

Challenges of Public History in a Community with a Secret," The Public Historian 16, no 2 (1994). It has never been confirmed that the body there actually is Wesley Everest, though, although there is a photograph at the Kirk Library in Centralia of the actual removal of Everest's body from the police station. ${ }^{11}$ This particular image has been used on several sites, but its origins come from an individual's work through ancestry.com about a Washington National Guardsman named Emil Rennen, who is supposedly in the photo. All citations the author has seen note possible inaccuracy of the photo. It is included here to encourage further research on its veracity. 
Wobblies, they made closure on Everest's fate difficult. This decision served the Labor countermemory framework of the Tragedy story, as it perpetuated interest in the injustice done to Everest. ${ }^{12}$

\section{What news is fit to print?}

The 1910s and 1920s were a challenging period for organized labor in the United States, and the Wobblies, more than any other labor group, bore the brunt of nationwide crackdowns during and immediately after World War I. Unlike the American Federation of Labor, which had largely made its peace with the American capitalist enterprise, the Wobblies advocated a revolution that would overhaul the American economic system. Even as this revolution counted a few earlier victories, such as the Free Speech Fight in Spokane in 1908, it came under heavy attack with the onset of war. ${ }^{13}$ In the Northwest, the Everett Massacre of 1916 and the Seattle General Strike in February of 1919 no doubt influenced how citizens viewed the labor movement. Even events that maintained a nonviolent approach, like the Seattle General Strike, were nevertheless labeled radical and un-American. ${ }^{14}$ Because the Wobblies never disavowed violence as a means for revolution, they were often categorized as violent even when the vast majority of their protests were not. ${ }^{15}$

\footnotetext{
${ }^{12}$ Irish, 117. Irish declared that the location of Everest's grave was well known and the controversy around Everest's resting spot a moot point. This will be in direct contrast to the reaction received by historian Robert Weyeneth reviewed in chapter 3.

${ }^{13}$ John Rayback, A History of American Labor (New York, The Free Press, 1959), 244.

${ }^{14}$ Colin Anderson, The Industrial Workers of the World in the Seattle General Strike," Strike: Seattle General Strike Project. http://depts.washington.edu/labhist/strike/anderson.shtml (accessed on August 12, 2015). It should be noted that the General Strike was championed by the AFL and the Wobblies together. ${ }^{15}$ Philip Taft and Philip Ross, "American Labor Violence: Its Causes, Character, and Outcome," in The History of Violence in America: A Report to the National Commission on the Causes and Prevention of Violence, ed. Hugh Davis Graham and Ted Robert Gurr, 1969. Chapter retrieved from: http://www.ditext.com/taft/violence1.html (accessed on August 12, 2015).
} 
Walker Smith's 1922 pamphlet Was it Murder?, which was sympathetic to the Wobbly cause, had claimed how in the immediate aftermath of the Tragedy mainstream press reporting was notoriously one-sided against the I.W.W. The sustained rhetoric against the Wobblies explains why many Americans were quick to accept the notion that the Wobblies had initiated the violence in Centralia. They may have been further inclined after reading about the "Palmer Raids," the anti-radical crackdown by Attorney General A. Mitchell Palmer and the newly formed Bureau of Investigation, which had also started in January of 1920. This militant onslaught against labor groups, whose goal Palmer claimed was "the destruction of the State," gained significant traction after the Centralia Tragedy. The "means of battle" that Palmer insisted the groups wanted to employ were now in evidence, he claimed, and public safety demanded a quick and decisive response. ${ }^{16}$ Scholars and observers corroborate Smith's analysis, most recently former Chronicle editor Brian Mittge, who wrote a thesis on the coverage of the local papers, particularly the significant anti-Wobbly stance taken by his own newspaper. ${ }^{17}$

The Centralia local press, the Centralia Daily Chronicle and the Centralia Hub, had been demonstrably anti-Wobbly well before Armistice Day. The Chronicle railed about how city leaders needed to address their "Wobbly problem," while the $H u b$ helped organize those same leaders at call to action meetings in the late summer and early fall of 1919. ${ }^{18}$ They did not change their tone after the deaths of the Legionnaires, continuing to rage against the Wobblies, whom they completely faulted for the Tragedy. The front page

\footnotetext{
16 “Palmer Upholds Red Repression,” New York Times (New York,NY), Jan. 24, 1920.

${ }^{17}$ Brian Mittge, "Framing Tragedy: The Centralia Chronicle's Changing View of its 1919 Hometown "Massacre.”(University Scholars Thesis, Seattle Pacific University, 2004).

${ }^{18}$ Centralia Hub, (Centralia, WA), June 26, 1919.
} 
of the December 5, 1919 edition of the Chronicle bluntly asked the community, "Which Side Are You On?"19

National papers did likewise. The Portland Oregonian presented only the Legionnaire perspective, and the Seattle and Tacoma news followed suit. ${ }^{20}$ When word of the massacre appeared in the New York Times, the headline clearly noted its perspective: "IWW Band Routs Ex-Servicemen; Fighting Starts Near Centralia."21

The only papers that considered the Wobbly side to the tragedy were the Labor presses. But even their coverage was tentative, not absolving the Wobblies but insisting that judgment be withheld until more facts became available. It was a tenuous time for union members generally, being in the midst of the First Red Scare. ${ }^{22}$ Playing off the tenor of the time, anti-Wobbly authorities seized the initiative after the violence, with raids at Wobbly houses in several cities. Further, the mere suggestion that the Wobblies were not at fault was enough "sedition" to cause the labor newspaper, the Seattle Union Record, to be raided, its editor arrested, and its presses seized. ${ }^{23}$ While the Union Record resumed printing soon after, that early crackdown tempered the typewriters of the Labor press from Los Angeles to Seattle.

Wobbly sources also claimed that Centralia leadership suppressed the media's portrayal of events even further. Later affidavits reported that a Pathe Company

\footnotetext{
19 “Which Side Are You On?” Centralia Daily Chronicle. (Centralia, WA), Dec. 5, 1919.

20 "Centralia Buries 2 of Heroic Dead." Morning Oregonian, (Portland, OR), Nov. 15, 1919.

21 "IWW Band Routs Ex-Servicemen; Fighting Starts Near Centralia," The New York Times (New York, NY), Nov. 16, 1919.

22 "The Red Scare in the 1920s: Collected Commentary," Becoming Modern: America in the 1920s (Washington, DC: National Humanities Center, 2012),

http://americainclass.org/sources/becomingmodern/divisions/text8/colcommentaryrs.pdf (accessed on July 1, 2015).

23 "New Attack on Centralia Soldiers; Seattle Union Record Suppressed," The News Tribune (Tacoma, WA), Nov. 13, 1919.
} 
photographer had been in Centralia during the entire process. Apparently either Centralia citizens destroyed the photographer's camera or confiscated the film before he was escorted out of town. ${ }^{24}$ When an Associated Press reporter, Edgar Rinehart, dispatched a "leak" from Dr. Francis Bickford, who said that the Wobbly Hall had been charged before shots were fired on the Legionnaires while completing the coroner's report in Centralia, that reporter was also banned from reporting in Centralia. ${ }^{25}$ Were these claims true, Wobblies then could argue that because these elements were suppressed from the official collective memory of the Tragedy, it was incomplete.

\section{Trial in Montesano}

The trial was not held in Lewis County, a sensible move considering enflamed opinions, either from still-frenzied Centralians or from a population that read only local papers. The venue was shifted to Montesano, the county seat in adjoining Gray's Harbor County. The defense did not feel this was far enough away for the trial to proceed fairly, but when Judge John M. Wilson was assigned the case, he cancelled the request to move elsewhere and insisted that the original change of venue was enough. Wilson had delivered one of the eulogies for the slain Legionnaires and was known for being antiLabor. His appearance on the bench, and his immediate decision not to grant a venue

\footnotetext{
${ }^{24}$ Letter from Ray Becker to Ralph Chaplin, Feb. 7, 1924. Ray Becker papers, Mss 2003, Folder 1/1, Oregon Historical Society Research Library. Becker mentioned this in several letters - as late as January 2, 1936 he is still discussing the Pathe Service photographer. The fact that the camera was smashed suggested that Becker felt that the photographs were somehow sympathetic to the Wobblies. A series of short film clips can be seen from after the Massacre at http://www.t3licensing.com/license/clip/3312945677_017.do (accessed May 26, 2014).

${ }^{25}$ Smith, 17. It is unclear who in Centralia did the actual banning of this reporter.
} 
change, insured a successful prosecution, but further opened the door to criticisms from Labor supporters. $^{26}$

The prosecution was conducted as a team effort, with the local prosecutor Herman Allen joined by several assistants. Most notable in this effort was Lewis County prosecutor C.D. Cunningham, who in most Labor accounts was a ringleader at Everest's lynching. Cunningham's papers today are one of several important sources about the trial. They are available at the American Legion National Archive as well as (partially) at the University of Washington. Cunningham and his family have been significant curators of the official memory framework, represented by the trial and its verdict. ${ }^{27}$ During the trial his litigation was generally textbook variety, but his knowledge of specific Centralians and his use of that knowledge to shape trial proceedings was duly noted by observers. ${ }^{28}$

The Wobblies were only tried for the death of Warren O. Grimm, the American Legion commander, even though four men were killed and others wounded. On the one hand, this could have been a carefully considered strategy to hold the other dead for future trials. ${ }^{29}$ However, the choice of Grimm could have been carefully calculated because of the prosecution's contention that the Wobblies fired first and without provocation. Unlike Arthur McElfresh, who was killed close to the Wobbly Hall, scholars like Irish contend that Grimm never left his position leading the American Legion parade

\footnotetext{
${ }^{26}$ Harvey O’Conner, Revolution in Seattle (New York, NY: Monthly Review Press, 1964), 170-197. O'Conner claimed the prosecution specifically retained attorney W.H. Abel on their team so that his brother, Judge George D. Abel, who was friendly to Labor and initially assigned to oversee the trial, would have to recuse himself and be replaced with Wilson, who was not.

${ }^{27}$ Brian Mittge (former Chronicle editor), in discussion with the author, July 26, 2014.

${ }^{28}$ Lampman, 20. "He used his knowledge of the event to "chilling effect."

${ }^{29}$ Ibid., 70. There are a few elements to this contention. First both Cassagranda and Hubbard were commonly thought to have been killed by Everest, who was already dead and could not be tried. So in earnest, the Wobblies left could only be tried for Grimm and McElfresh's deaths. The substance to the "one at a time" idea is somewhat substantiated in that after Smith and Sheehan were acquitted, they were immediately rearrested to stand trial for the death of Arthur McElfresh. That case never went to trial.
} 
and was most likely gunned down by a shooter from the nearby Avalon hotel. ${ }^{30}$ Thus including McElfresh would have made the prosecution much more difficult because the prosecutors would have to explain why McElfresh was so close to the Wobbly Hall when he died. By opting to focus only on Grimm, they had an easier route to demonstrating that the Wobblies had first conspired to attack the procession and that Grimm was killed while parading. ${ }^{31}$

The selection of jurors was belabored. It took nearly three weeks to fill a panel. Both prosecution and defense hammered away at the prospective jurors, and the months changed from February to March before they were seated and the trial began. The proWobbly side has frequently claimed that the prosecution installed one juror as a ringer Harry Sellers. While Sellers is identified as a laborer, affidavits and accounts from other jurors mention his advocating for a guilty verdict from the trial's onset, "proof" that he had been planted to swing the jury toward a conviction. ${ }^{32}$

The defense counsel was George Vanderveer, who had represented Labor causes nationally in losing efforts several times. He served alone, having rushed from Chicago to pursue the venue change. And while he had a staff and some investigators, they were abused verbally and physically as they traveled around Washington. The prosecution even stole Vanderveer's mail, which Wilson allowed them to introduce as evidence. ${ }^{33}$

\footnotetext{
${ }^{30}$ Irish, 73. Irish believes this based on his skepticism of the testimonies of defense witnesses for the trial.

${ }^{31}$ Vernon Jensen, Lumber and Labor (New York, NY: Farrar and Rinehart, 1945), 137-147, http://search.tacomapubliclibrary.org/unsettling/unsettled.asp?load=Centralia + Massacre \&f $=$ labor $\% 5 \mathrm{Ccentr}$ ali.mas (accessed May 24, 2014).

${ }^{32}$ DeWitte Wyckoff, The Centralia Case, a joint report on the Armistice Day Tragedy at Centralia, Washington, November 11, 1919 (Brooklyn, NY: Brooklyn Eagle Press, 1930), 25-26. Whether or not this is true is open to speculation. Sellers will not be the only juror who votes for conviction early on, and it may have been a way for those jurors who felt guilt for casting their votes to redirect blame to a "spy."

${ }^{33}$ Lampman, 56. The letter included discussed Vanderveer's various concerns on the trial, and the prosecution utilized this to show that his witnesses and conduct were suspect.
} 
Considering the advantage the prosecution started with, these tactics fed the Labor countermemory framework notion that the trial was a sham. This perception was accentuated when Vanderveer introduced the argument that his clients were not guilty because they were acting in self-defense against a citywide conspiracy, which Wilson disallowed, issuing the blunt rejoinder, "The issue in this case is murder, Mr.

Vanderveer." 34 Vanderveer was thus unable to submit any evidence of meetings prior to the raid held at the Elks Hall or the American Legion, or submit testimony about previous raids on the Wobblies, unless he could directly connect Grimm (and only Grimm) to those particular events.

As the trial unfolded, this became increasingly difficult for Vanderveer to do. Outside the trial, other events occurred that influenced its course. As the defense opened its case, a detachment of United States infantry troops appeared, to the surprise of Wilson and the indignation of Vanderveer. Allen explained to the court that he had requested their presence based on fears of a Wobbly raid on the courthouse. ${ }^{35}$ Affidavits from the jurors indicated that the bailiffs frequently told the jurors that they needed to be constantly present to protect the jury from Wobblies that were plotting violence. ${ }^{36}$ Some jurors later claimed that they were worried about their own safety from the troops should their verdict be in favor of the defendants. ${ }^{37}$

\footnotetext{
${ }^{34}$ Ibid., 44.

${ }^{35}$ Lampman, 40. Wilson apparently calmed down after meeting with Allen, with speculation being that he was more upset that he wasn't consulted on this as opposed to their actual presence. Vanderveer, probably rightly, just feared the impact their presence would have on the jury. There most likely was no possibility of a Wobbly raid, as most Wobblies had been rounded up and arrested well before the trial.

${ }^{36}$ Smith, 22. Vanderveer attempted to get a Bailiff removed because of this type of influence on the jurors, but Wilson refused when Vanderveer wouldn't reveal his source.

${ }^{37}$ Ibid.
} 
The prosecution steered potential witnesses away from testifying, a process Cunningham led. Beyond mere intimidation, the prosecution arrested defense witnesses for perjury immediately after they testified on behalf of the Wobblies. These arrests occurred in the courtroom with significant fanfare. While the perjury trials never went forward, they likely had their affect of scaring away potential witnesses who had already been wary about appearing in court. ${ }^{38}$

After closing arguments but before the jury was allowed to deliberate, Judge Wilson laboriously reviewed his instructions, leaving the jury in a precarious situation by instructing them to choose either first degree murder or acquittal. The jury rebuffed the judge's guidelines and returned a verdict to him finding only five of the defendants guilty. Wilson refused to accept the initial verdict and sent the jury back to reconsider. They returned this time finding seven men guilty of murder in the second degree, finding Loren Roberts innocent by reason of insanity, and declaring the remaining two defendants innocent. ${ }^{39}$ The jury also specifically asked Judge Wilson for leniency in his sentencing. Wilson ignored that request and proceeded to sentence the convicted defendants to 25 to 40 years in prison. Roberts, because of his insanity, was indefinitely committed to an asylum. The verdict incensed both the prosecution and defense.

For students of collective memory, the trial is a moment for understanding the way in which the Tragedy is remembered. Had some of the defense's requests been granted early on, from the change of venue to the presentation of the conspiracy angle, it would be hard for Labor supporters to cry foul and begin the process of crafting a

\footnotetext{
${ }^{38}$ Lampman, 52.

${ }^{39}$ Tom Copeland, The Centralia Tragedy of 1919: Elmer Smith and the Wobblies. (Seattle, WA: University of Washington Press, 1993), 84. In reviewing affidavits, it seems that the jurors were seeking a compromise scenario for themselves, worried about reprisals from both sides.
} 
compelling countermemory. The nature of these occurrences, combined with the presence of federal troops and prosecution chicanery like reading stolen mail and intimidating witnesses, all contributed to a palpable feeling that the Wobblies had been further wronged. It was this sense of injustice toward this already marginalized group that carried the Centralia story far beyond the city.

\section{Competing Perspectives: Lampman and Chaplin}

In the aftermath of the trial, supporters of both sides penned opposing narratives, which became the basis for the official collective memory framework and the Labor countermemory framework. One is an account crafted at the behest of the American Legion, written by Oregonian reporter Ben Hur Lampman. Chaplin crafted a pro-Wobbly version. They presented two very different perspectives on the events of the case, both claiming legitimacy.

Lampman's work, Centralia, Tragedy and Trial, began with an appeal to authority. It included a foreword by the National Commander of the American Legion, F.W. Galbraith, that announced that Centralia was of "particular significance" to the American Legion because it was where "the blood of four murdered comrades [were] stricken down unawares by the cowardly hand of anarchy." ${ }^{, 40}$ A second foreword by General Leonard Wood stated that "never was there a more unprovoked and cowardly attack than this, and it required the highest degree of self-restraint and the highest respect

\footnotetext{
${ }^{40}$ Lampman, Foreword.
} 
for Law and Order on the part of the Legionnaires to turn these willful assassins...to the courts for an orderly and fair trial.",41

Lampman included a map and a three-page overview of the Tragedy following these forewords. The map is noteworthy because of how Lampman located the wounded on the map. What immediately sticks out is McElfresh's positioning. While the other three victims are distant from the Wobbly Hall, McElfresh is right next to it on the map. In his text, Lampman noted that McElfresh was hit while trying to "seek cover." 42 The remainder of the overview is succinct, with Everest's arrest declared simply: He was "overwhelmed by other ex-servicemen" after fleeing toward the river. ${ }^{43}$

${ }^{41}$ Ibid., Second Foreword.

${ }^{42}$ Ibid., 8 .

${ }^{43}$ Ibid. 


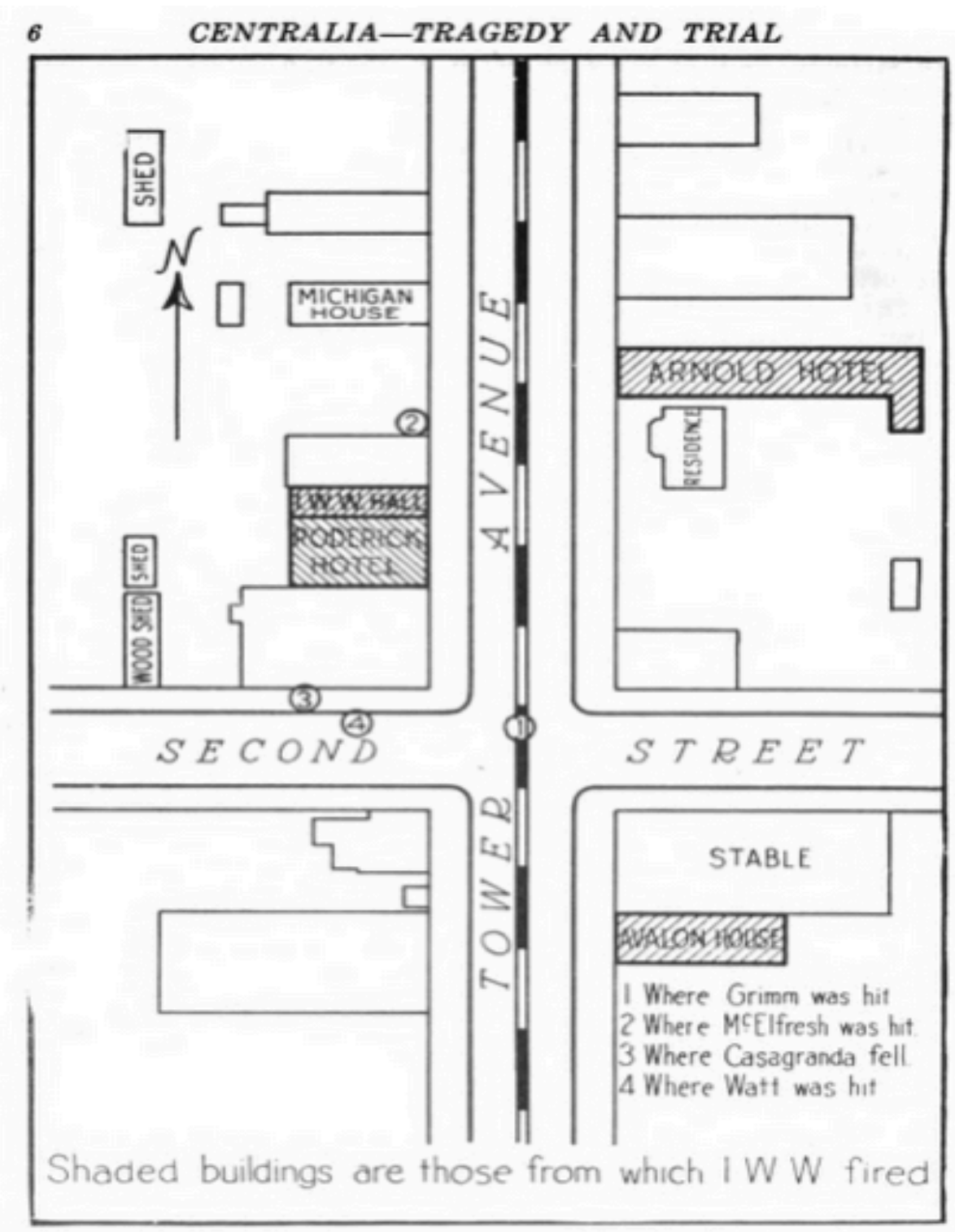
Map of section of Centralla, Washington, where the Armistice Day parade was
ambushed by members of the $\mathbf{I}$. W. W.

Fig. 3. Ben Hur Lampman, Map of Massacre, Centralia Trial and Tragedy (Centralia, WA: Grant Hodge American Legion Post, 1920), 6. The Roderick Hotel (Wobbly Hall) is in toward the center on the left).

Lampman continued with an overview about World War I, and how Americans forgot the sacrifice of the "valiant and high-hearted boys who crossed the submarine 
lanes to suffer and die gloriously in France." ${ }^{44}$ He referenced "the concept of the soviet," which he tied to the "I.W.W. murderers" on trial. ${ }^{45}$ This backdrop, an ungrateful American public unaware of the menace posed by a Soviet-influenced Labor group, is the context under which Lampman placed the tragedy before he related the events of the trial. The "cowardly verdict" had already been rendered when Lampman completed the text, and he accounted for that by saying that it was crafted by "fear-haunted minds." 46

At no point in the introduction is the reader presented with what Lampman hoped to gain in this account. His absence of context other than the soviet threat is in stark contrast to The Centralia Conspiracy, where Chaplin extensively detailed all that happened prior to the Tragedy. Since the Legionnaires were trying to justify the outcome of the trial, this makes sense. Lampman claimed that the 25 - to 40 -year verdict handed down by Wilson was unsatisfactory because the Wobblies deserved a steeper punishment. This only augments the tenacity of the official collective memory framework. Dissatisfaction with the verdict, even as it was favorable to the Legionnaires, leaves the impression that the Wobblies had somehow duped the system.

It is in his discussion of Wesley Everest, however, where Lampman revealed his aim. Lampman did not skirt Everest's lynching. Rather he took it head on, calling it an "unlawful error." ${ }^{, 47}$ More than unlawful, his tract lamented the inconvenience of the lynching, since it "afford[ed] additional propaganda for the radicals" and added "greater harm" since "it removed from the trial one of the ringleaders of the Centralia reds, against

\footnotetext{
${ }^{44}$ Ibid., 10.

${ }^{45}$ Ibid., 9-10.

${ }^{46}$ Ibid., 13.

${ }^{47}$ Ibid., 15.
} 
whom evidence was damningly complete and conclusive. ${ }^{48}$ Hidden in that phrasing, of course, is the subtle suggestion that the evidence against the other defendants was neither complete nor conclusive. He swiped at Everest's depiction by the Wobblies and tried to unfurl some of the mythos surrounding Everest by suggested that Everest was a draft dodger and had a violent temperament. ${ }^{49}$ He cleverly used this demythologizing to correct what the American Legion felt were lingering assumptions from the trial. Lampman concluded the segment on Everest by linking his case of mistaken identity to another Wobbly misassumption: that they were going to be raided on Armistice Day. Lampman's efforts in this regard were effective for his Legionnaire readership, providing them balm for the guilt they might have felt about the lynching.

In the remainder of Centralia Trial and Tragedy Lampman reviewed the trial, castigating Vanderveer while extolling the prosecution. Lampman regularly included courtroom dialogue, highlighting defense mistakes and prosecution triumphs, such as when prosecutor W.H. Abel produced the stolen letter. Rather than question the legality of this, Lampman remarked: "how the letter came into the hands of the state... is quite immaterial to the present narration. ${ }^{, 50}$ Later critiques of Centralia: Trial and Tragedy cited Lampman's consistent hyperbole, whereby no defense witness was anything but a perjurer and every witness for the prosecution was noble and unimpeachable. ${ }^{51}$

Lampman concluded by assessing the defense's contention that "there existed a conspiracy to rout the I.W.W. from the city." "Of such there was no proof," he insisted,

\footnotetext{
${ }^{48}$ Ibid.

${ }^{49}$ Ibid.

${ }^{50}$ Ibid., 58.

${ }^{51}$ Lawrence Skoog, "The Centralia Case: Three Views of the Armistice Day Tragedy at Centralia, Washington, Nov. 11, 1919 by Ralph Chaplin; Ben Hur Lampman." Oregon Historical Quarterly 73, no. 1 (1972): 70-71.
} 
adding, "indisputably, whatever rumors have spurred the I.W.W. fear, is the truth that the marching Legionnaires did not attack until fired upon." ${ }^{, 52}$ Within these summations were additional charges of "myriad cloaked and treasonable acts" committed by the "Wobblies," such as their opposition to American involvement in World War I. Ultimately, the men may have turned out okay had it not been for the influence of the I.W.W., whose treachery Lampman insisted America be "done with.",53

Reading Lampman, it is easy to see the vivid connection to the zeitgeist of the First Red Scare. The influence of the Republican, anti-Communist Oregonian is clear. His stance would have been popular during the period, and his lack of context forgiven because he identified the International Workers of the World as the utmost threat of the times, a common perception. It is therefore easy to see why his characterization of the defendants and their defense team as traitors could be upsetting and divisive, and further foment a desire by their sympathizers to "set the record straight" with regard to the Centralia Tragedy.

Chaplin's The Centralia Conspiracy was released in May of $1920 .{ }^{54}$ Chaplin did not attend the trial (he was reportedly hiding in a Seattle bunkhouse), which is evident from the lack of detail about it. While he began by talking about the "tangled mesh of circumstances" that befell Centralia on Armistice Day, Chaplin devoted far more ink to the context of the Tragedy than Lampman. ${ }^{55}$ In doing so he intended to present a defense

\footnotetext{
${ }^{52}$ Lampman, 72.

${ }^{53}$ Ibid.

${ }^{54}$ Eugene Nelson, Introduction to The Centralia Conspiracy, 1973 edition, (http://ecology.iww.org/texts/RalphChaplin/centralia-conspiracy/0 (accessed on May 12, 2015). I reference these various editions as the version being used for this thesis is the 1920 version, of which part was written in 1919 during the heat of events, but the remainder was finished after the trial. A 1924 version contains more information about the trial also omits some elements of the 1920 tract.

${ }^{55}$ Chaplin, 4.
} 
of the I.W.W. in general, as opposed to just the Centralia defendants, since the I.W.W. was under sustained attack throughout the country.

Consequently, Chaplin detailed events in the entire Western Timber country and not just in Centralia. This choice diminished the plight of the Centralia defendants, one of whom, Ray Becker, later voiced his dissatisfaction with Chaplin's work. ${ }^{56}$ Yet Chaplin wrote for a wider audience, and so he presented an expansive portrait of many of the key players in the case. Instead of focusing on the legal wrangling of Vanderveer, Wilson and Allen, who he believed were not directly impacted by the Centralia Tragedy, Chaplin tried to illustrate those whose lives were directly affected by the region's ongoing Labor struggles.

The first quarter of the pamphlet built toward discussing Centralia. Chaplin wrote about the origin of the timber industry and the division of labor at the mills, separating the workers between those who operated the mills and were more settled in communities, and the lumberjacks who were more migratory and seasonal. He described the tensions between them and posited that management stoked divisions between the two groups. ${ }^{57}$ Chaplin also chronicled various Labor flare-ups in the Northwest, including the free speech riots, a 1917 timber strike, and the violent repression of workers in Aberdeen and Everett, Washington. ${ }^{58}$

But the most important context that Chaplin included concerned the 1918 raid on the Centralia Wobbly Hall, an event unsurprisingly missing from Lampman's account.

\footnotetext{
${ }^{56}$ Letter from Ray Becker to Ralph Chaplin, Feb. 7, 1924. Ray Becker papers, Mss 2003, Folder 1/1, Oregon Historical Society Research Library. A short note on top of the official letter addressed Chaplin derisively as the "Ham Poet of Labor."

${ }^{57}$ Chaplin, 12-14.

${ }^{58}$ Ibid., 18-32. It is worth noting that the 1917 Timber Strike was successful in earning an 8-hour day for workers. At the same time, is may have been a pyrrhic victory for Wobblies, since it took place during World War I, labeling the strikers as unpatriotic - a tag that would stick after the war.
} 
Chaplin is the first to draw attention to this. "You must remember that there were two halls raided in Centralia; one in 1918, and another in 1919." ${ }^{59}$ After a series of bitter attacks in the pages of both the Centralia Chronicle and the Hub, city leaders eliminated it. During a Red Cross Parade in April of 1918, a mob of Centralia citizens raided the hall, which "the loggers did not defend, and...were manhandled by the mob." 60 Additional accounts of this event detail the purloining of Wobbly-owned goods and the burning of books and papers. After exiling the Wobblies from town, the city leaders publicly auctioned the goods among themselves. ${ }^{61}$

This context is important for understanding the development of different narrative frameworks of the Tragedy. The official framework begins with the events of November 11, 1919, while the Labor countermemory always includes the conditions that precipitated the event. According to Chaplin, "Judge Wilson refused to permit the jury to see either the photographs or the hall," so that the first time this event appears in the greater memory of the Tragedy is in this Chaplin's pamphlet. ${ }^{62}$ It should seem evident that the 1918 raid would be a pivotal part of the story, because if Wobblies were present for that experience, their memories - the rough treatment, the hawking of goods -colored their disposition toward a second raid. It also could warrant additional consideration of the guilt of the Centralia defendants. Chaplin pondered whether, had the jury had learned about the 1918 raid, they would have convicted the Wobblies. ${ }^{63}$

\footnotetext{
${ }^{59}$ Ibid., 33.

${ }^{60}$ Ibid., 33.

${ }^{61} \mathrm{Ibid}$.

${ }^{62}$ Ibid., 35 .

${ }^{63}$ Ibid.
} 
Chaplin became more Centralia-specific after discussing the Red Cross raid. He introduced prominent citizens in Centralia, like President of the Employer's Association of Washington, F.B. Hubbard, American Legion Commander William Scales, and Grimm. It appears that Chaplin is trying to do what Vanderveer could not in court establish the grounds for the argument that the Wobblies were responding to an ongoing conspiracy. He presented events to demonstrate ongoing hostility to the Wobblies, such as the banishing of blind Labor-press vendor Tom Lassiter. He also recast the "heroic" Warren Grimm, the star football player, war hero, and leader amongst Centralians. ${ }^{64}$ Chaplin's characterization is radically different, with Grimm described as cold and unreasonable. Chaplin amplified those traits in his text by isolating Grimm's appearances to vignettes where he converses with Elmer Smith. Since in those vignettes Smith champions justice for Lassister or seeks to protect the defenseless Wobblies, Grimm comes off as ghoulish. ${ }^{65}$

Chaplin continued to explain the various meetings that took place after the new Wobbly Hall was completed near the Roderick Hotel, and presented meeting agendas and newspaper clippings that described Centralia elites aligning against the Wobblies.

Chaplin also described a handbill printed by the Wobblies in advance of the 1919 raid that asked for police protection. This flyer, "To the good citizens of Centralia," didn't call for action, but aimed to alert them to the vitriol about the Wobblies printed in the Hub. Chaplin explained its purpose was also to emphasize that the Wobblies had never reacted violently to the mobs that had attacked their hall, and that though Wobblies had been

\footnotetext{
${ }^{64}$ Ibid., 39. Lassiter sold Labor-friendly papers like the Seattle Union Record on Centralia street corners. In June of 1918, Centralia citizens accosted Tom, beat him, and threw him into a ditch outside of town. ${ }^{65}$ Ibid., $39,58$.
} 
indicted across the country, no one had been convicted because their "only crime is solidarity, loyalty to the working class and justice to the oppressed."

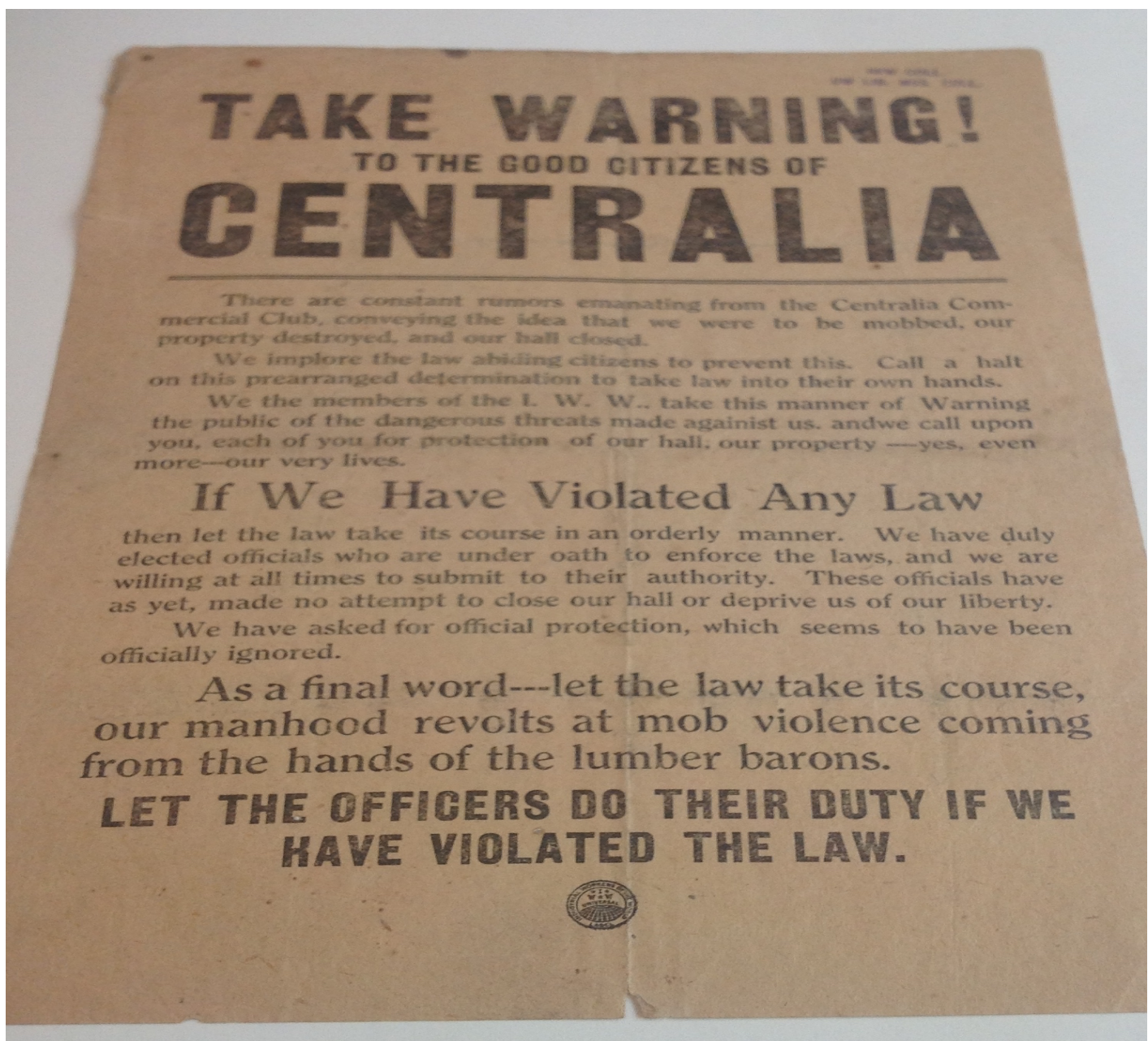

Fig. 4. "Take Warning! To the good citizens of Centralia," 1919, University of Washington I.W.W. digital collection, Centralia Massacre collection, http://digitalcollections.lib.washington.edu/cdm/singleitem/collection/iww/id /37/rec/1 (accessed July 5, 2015).

Chaplin's version of events highlighted the treatment of Wesley Everest. He is the first to claim that Everest was castrated while being transported to the bridge for his

\footnotetext{
${ }^{66}$ Ibid., 56. Chaplin doesn't comment on what he thinks the Wobblies were hoping from this handbill. Chaplin's depiction of the raid differed from Lampman with the obvious distinction being that the Legionnaires charged the Hall before shots were fired. In inspecting the document above, there is noted discrepancy between what Chaplin relates was in the handbill and what was actually printed on the document.
} 
lynching, Everest was castrated in the car. "Reaching into his pocket," Chaplin wrote, "he produced a razor. For a moment he fumbled over the now limp figure in the bottom of the car...suddenly there was a piercing scream of pain. The figure gave a convulsive shudder of agony." Everest is then reported to have said, "For Christ's sake, men; shoot me don't let me suffer like this." ${ }^{67}$

The remainder of The Centralia Conspiracy appraised the Tragedy's aftermath the regional manhunt for Wobblies and the basic set-up for the trial. Chaplin contended that the courthouse was less about the defendants, and more about "A Labor Movement on Trial." He concluded the piece with a lengthy discussion of a conspiracy that was out to crush the I.W.W. through the courts. The pamphlet's final pages are actually devoted to a "frequently asked questions" section in which a Labor Jury that was sent to Montesano to watch the trial explained why the defendants were not guilty ${ }^{68}$

These two pamphlets by Lampman and Chaplin serve as the original documenting of the official collective memory framework and the Labor countermemory framework of the Centralia Tragedy. ${ }^{69}$ In all likelihood locals read only one of the two accounts. Those who read Lampman's account, presented with neither context for the event nor details of Everest's lynching, could see the Tragedy as a murderous rampage by the I.W.W., for which the convicted Wobblies were justly imprisoned after a fair trial. Conversely, those

\footnotetext{
${ }^{67}$ Irish, 118-120. Irish believed that Chaplin included this to encourage sympathy to Everest, who to this point had been portrayed unfeelingly; Chaplin, 70. Chaplin doesn't add more detail here; the reader is left to wonder what the "cutter" had done. He is next described as leaving the car with bloody hands and is, according to Chaplin, "known to everybody in Centralia. He is still at large."

${ }^{68}$ Ibid., 78.

${ }^{69}$ The University of Washington Centralia Massacre collection, the Ray Becker papers at the Oregon Historical Society, and the Kirk Library Centralia collection all contain multiple pamphlets from both perspectives, released by the American Legion and various Wobbly release committees that follow these two. Other reports appeared in the New Republic and the Christian Century, as well as in newspapers and other periodical. This thesis cannot review them all, but encourages scholars to examine should further research be sought.
} 
who only read Chaplin, with the courtroom entirely removed, Wobbly self-defense was appropriate given the consistent hostility in Centralia and the treatment of Everest. These initial kernels of collective remembering (and to a certain extent, collective occlusion and amnesia), would be only complicated by remembrances that followed over the next 30 years.

\section{The Sentinel takes his post}

At the conclusion of Centralia Trial and Tragedy, Lampman included an address by another American Legion commander, Franklin d'Olier, at the grave of Warren Grimm. d'Olier argued that the events of the Tragedy were intertwined with the organization, that the "ink was scarcely dry on the words... of the constitution of the American Legion... when the Legion men of Centralia proved how sincere was their stand for law and order."70 The four men who died, d'Olier insisted, "will be beloved martyrs of the American Legion," because they "died as heroically as they had made the supreme sacrifice over there." ${ }^{, 71}$ Commander d'Olier intertwined the Tragedy with the mission of the Legion, shifting the focus of the day's events from a local raid gone amok to a grander patriotic narrative. Granting the four men martyr status, equating their deaths in the streets of Centralia with men who died in the Argonne Forest, encouraged a mindset that took hold. In the months that followed, the American Legion and its supporters started an effort to fully memorialize their martyrs. By 1922, the Centralia Monument Association had been created to tackle the task, and a committee that included the lieutenant governor and a Seattle newspaper publisher raised funds to erect a statue by

\footnotetext{
${ }^{70}$ Lampman, 75.

71 Ibid.
} 
Alonzo Victor Lewis, “The Sentinel.” It was unveiled in Centralia's George Washington Park to great fanfare in $1924 .^{72}$

The statue was installed with the inscription "To the memory of Ben Cassagranda, Warren O. Grimm Earnest Dale Hubbard, Arthur McElfresh. Slain on the streets of Centralia, Washington, Armistice Day Nov. 11, 1919, while on peaceful parade wearing the uniform of the country they loyally and faithfully served." ${ }^{, 73}$ Here in bronze and stone, for posterity, was the shrine that the American Legion had hoped for, based on the tribute d'Olier had offered. Grimm, Cassagranda, McElfresh and Hubbard had their "service" equated with that of soldiers who died overseas. Their wearing of uniforms on Armistice Day was duly noted, and most importantly, they were walking peacefully when they were brutally slain.

The Sentinel is the critical element of all collective memory studies of Centralia. It is the transmitter of the official collective memory framework, and when it was erected, its creators meant it to be that way. They believed, like with any monument, it would outlive their ability to tell the tale. Since then, even when interest in the Tragedy reduced to a trickle, the statue remained. It has served as the origin for many studies of the Tragedy enshrining the Legionnaire narrative and requiring any different view to counter it. It figured prominently in all Labor countermemory efforts to recapture the primacy of the Tragedy story, and is a starting point for most efforts that make up the academic framework. When a memory of the Tragedy is challenged, it almost always starts with the Sentinel.

\footnotetext{
${ }^{72}$ Centralia Daily Chronicle, (Centralia, WA), Nov. 10, 1924.

${ }^{73}$ Weyeneth, 5.
} 


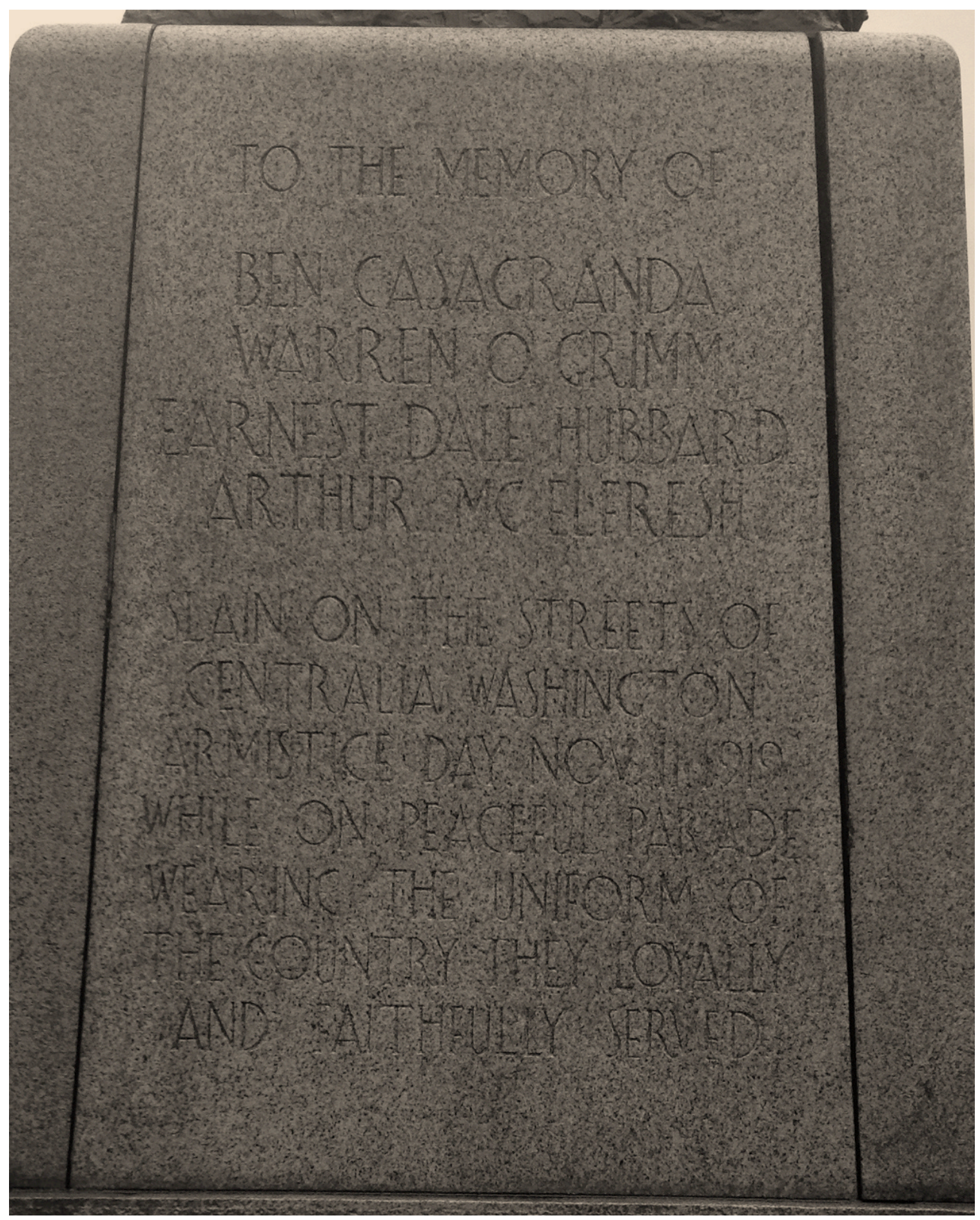

Fig. 5. Inscription on the Sentinel statue, 1924, photo taken by the author, 2013. 


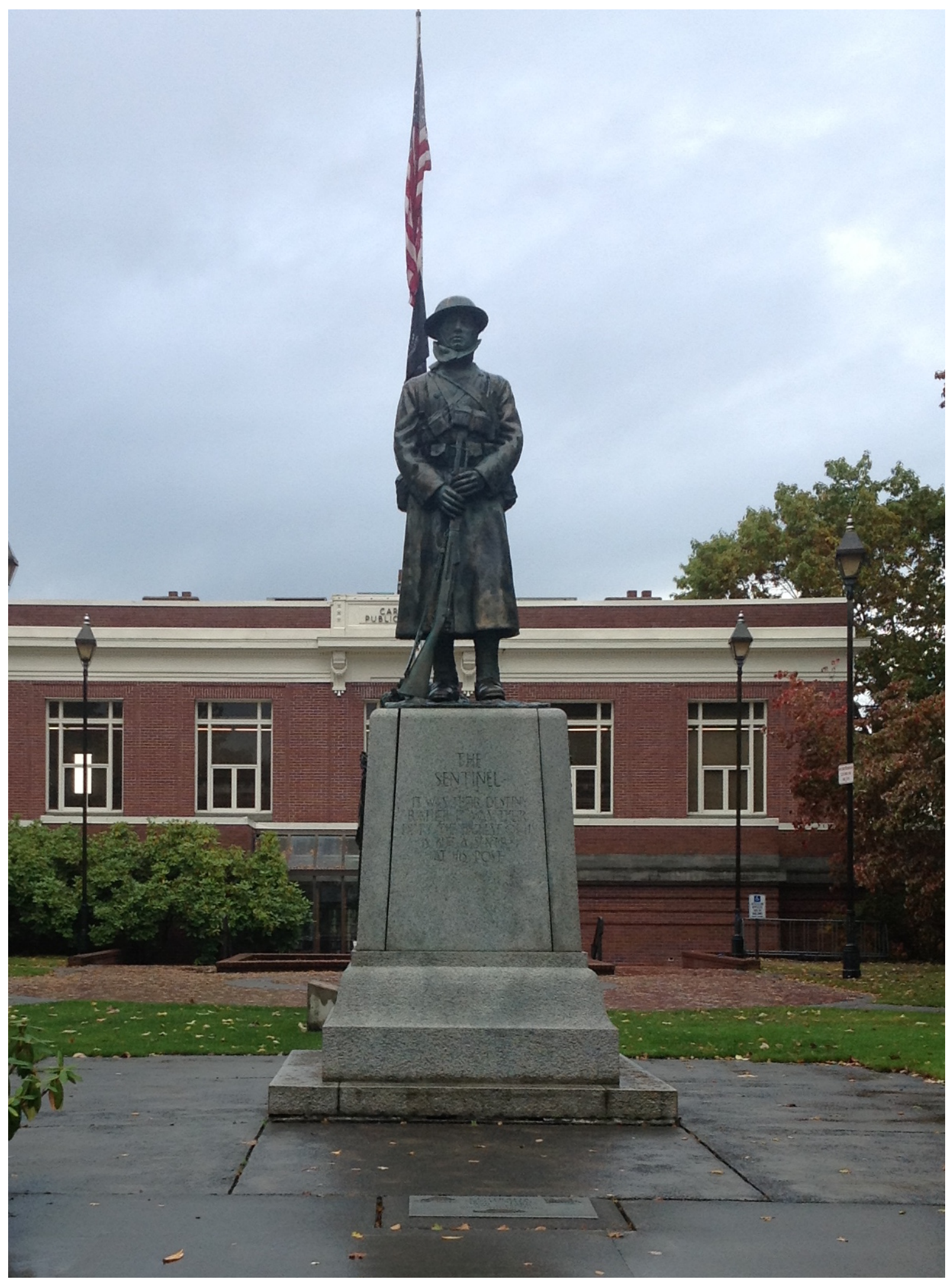

Fig.6. The Sentinel statue, photo taken by the author, 2013. 


\section{Was it Murder? Later Examinations of the Centralia Defendants}

Between 1920 and 1924 first efforts were made on behalf of those convicted at the Centralia Trial. The six convicted men, Ray Becker, Eugene Barnett, James

McInerney, O.C. Bland, Bert Bland, Britt Smith and John Lamb were shipped to the state penitentiary in Walla Walla, Washington to serve their sentences. After appeals failed, various groups continued to work for their release, most led by Elmer Smith. Smith and his supporters began compiling affidavits of Centralia citizens who had been present or affiliated with the Tragedy. Even though these documents had no legal standing, supporters felt they might sway public opinion. Most prominently they gathered the affidavits of jurors from the trial, most of who claimed that they had made a mistake in voting for a guilty verdict.

In 1922, Walker C. Smith compiled many of the early affidavits in a pamphlet entitled Was it Murder? The Truth about Centralia. Smith's work was a continuation of Chaplin's, filling in the gaps about the trial that Chaplin left out. It also served as a second attempt to counter Lampman. ${ }^{74}$ For example, Smith cited juror E.E. Torpen, who disclosed that the jury had been predisposed to a "not guilty" verdict but felt goaded into a guilty decision. Further, he revealed that the jury believed incorrectly that its recommendation of leniency would bind the judge to a less severe penalty. ${ }^{75}$ Smith pointed out incidents where witnesses impugned by Lampman were more dependable than initially noted. He referenced the case of Guy Bray, who was charged with perjury

\footnotetext{
${ }^{74}$ The author would propose that in trying to understand the two perspectives of the trial, one should read Lampman, and then Chaplin and Smith together as one text. In the 1970s De Capo Press released all three pamphlets together as one tract, which is available from many Northwest regional libraries.

${ }^{75}$ Smith, Was it Murder? 9-10.
} 
after testifying but never brought to trial. To Smith this confirmed Bray's testimony, that Grimm was not at the front of the parade as the prosecution claimed. ${ }^{76}$

Above all, Smith's work questioned the conduct of the original trial. At best Smith might have hoped for a pardon, or he might have been hoping to challenge the prevailing collective memory of the trial that had been shaped by Lampman's depiction. Smith evaluated the ways in which the state worked to define the story against the Wobblies. In a section entitled "How Public Opinion was Manufactured," Smith detailed how the Governor, allied with a group called "The Loyal Legion," leveraged their influence to shape public opinion about the Tragedy, not least by getting supporters to give four-minute speeches in movie theaters prior to shows. ${ }^{77}$ Researcher Lawrence Skoog even lauded Smith's pamphlet for its even-handedness because it interpolated comments about how the mood of the time affected the jurors. One, W.E. Immon, confessed to Smith: "I was afraid that a hung jury would mean a new trial with a worse jury, and that innocent men would be put to death. So I voted for a second degree against seven and an acquittal for two. It seemed better that way, with two of the men free to work for the release of the others."

Was it Murder? didn't change anything for the Centralia prisoners, who remained in Walla Walla through the 1920s, but it certainly added weight to the countermemory of the tragedy, as efforts to release the prisoners did not abate. Their situation was regularly reported in the Labor press, and support groups organized throughout the Northwest, most prominently in Seattle and Centralia. Immon's hope, that the two acquitted

\footnotetext{
${ }^{76}$ Ibid., 11.

${ }^{77}$ Ibid., 16.

${ }^{78}$ Ibid., 23.; Skoog, 71.
} 
Wobblies would serve to see the others freed, proved half correct. While Mike Sheehan vanished from the historical record, Smith devoted the rest of his short life to getting the other seven out of prison. Smith founded the Centralia Publicity Committee (CPC) in 1921, setting up shop in his law office on Tower Avenue in Centralia near the Tragedy site. Up until 1924, his work on the case had been steady and hopeful, but the 1924 Washington Gubernatorial election, which placed anti-Wobbly Republican Roland Hartley in office, ushered in a quiet period, as Hartley made it quite clear that he would neither pardon nor parole the Centralia prisoners. ${ }^{79}$

By the end of the 1920s Smith had made no significant progress. The cause was starting to fade from public attention. Author Tom Copeland has noted that, while Smith regularly spoke about the Centralia prisoners at local and national engagements, more often than not the audience was less interested in the prisoners than in his clever oratory ${ }^{80}$ More problematic was the fact that local workers who had contributed funds were starting to pull back. An ongoing rift between the imprisoned Wobblies and the national office about strategy, and the successful effort by Smith's political adversaries to disbar him further complicated efforts. ${ }^{81}$

In the late 1920s, efforts to reignite the movement to free the Wobblies revived, jumpstarted by a surprise advocate. In 1928, Edward Coll moved to Washington. Coll was a member of the American Legion and an insurance salesman. While selling insurance he learned that local workers had a negative impression of the Legion because

\footnotetext{
${ }^{79}$ Copeland, The Centralia Tragedy of 1919, 155.

${ }^{80}$ Ibid., 142.

${ }^{81}$ Ibid., 149-151. Wobblies in prison disagreed on whether they should take deals simply to get out of prison, which some did, or wait until their charges were reversed. This rift became very tangible when those that stayed eventually were released. Smith's political adversaries mounted a successful effort to disbar him, though he was eventually reinstated.
} 
of Centralia. He was disturbed by what he heard. ${ }^{82} \mathrm{He}$ traveled to Centralia, talked to citizens, and even interviewed C.D. Cunningham ${ }^{83}$ Coll concluded that the Centralia Wobblies had been wrongfully convicted. He sent a letter to American Legion posts explaining how they had been in the wrong. Elmer Smith latched onto this letter and began using it for publicity, hoping that the activism of an American Legionnaire would stir attention. Coll frequently flaunted his position as an American Legion member to draw attention to the plight of the imprisoned Wobblies. He engaged in a very public and heated debate with Cunningham, in which Cunningham claimed that he held Arthur McElfresh as he died, which Coll pointed out meant he was one of raiders of the Wobbly Hall. Cunningham left the debate after several brutal, personal attacks on Coll. ${ }^{84}$ Coll also appeared at several parole hearings, his energy and rhetoric reinvigorating the effort. ${ }^{85}$

\section{The Church Report}

Coll's efforts, and perhaps Cunnigham's malevolent reaction in debate is important because it spurred another evaluation of the Tragedy. This time it came from the academic sphere.

Coll's challenge to the official memory framework of the Centralia Tragedy led to the Puget Sound Methodist Conference to call for a thorough and impartial investigation into the events of the Centralia Tragedy. While the Methodist Board of Washington initially squashed this call, they later relented and allowed an investigation carried out in

\footnotetext{
${ }^{82}$ Edward Coll, interview by Eleanor Walden, June 26, 1979, http://centralia.sdlhost.com/\#/item/000000011042870/view (accessed on May 26, 2014).

${ }^{83}$ Copeland, The Centralia Tragedy of 1919, 165.

${ }^{84}$ Ibid., 167-168.

${ }^{85}$ Ibid. This scenario will be replicated in the 2000s; the idea of an American Legion member commenting on the Tragedy in any way other than in support of the Legionnaires seems to have always garnered attention. It should also be mentioned that Coll eventually requested $\$ 150 /$ month to do the various speaking engagements on behalf of the Centralia prisoners, which Elmer Smith found ways to pay.
} 
a collaborative effort with local Catholic, Jewish, and Protestant organizations. They tapped a young lawyer, DeWitte Wyckoff, also a trained theologian, to lead the inquiry. While Wyckoff's investigation proceeded, Smith and Coll continued working toward the prisoners' release. They also worked with the families of the prisoners to help them through the longer time in jail. Eugene Barnett's wife wanted to divorce him, which increased his desperation to be released, while Ray Becker, afflicted by what Copeland felt was prison sickness, began to resent the other prisoners and anyone who worked with him on the cases. ${ }^{86}$ In 1930, James McInerney died of tuberculosis, while Loren Roberts, who had been put away for insanity, had been declared sane and scheduled for release. ${ }^{87}$

Wyckoff released what is referred to as the "Church Report" to some fanfare in 1930. Like the Montesano verdict, it pleased few. The report asserted: "the outstanding feature of this whole series of events was the passion of the community, which made sound moral judgments impossible. Both sides used social dynamite and neither seems to have realized the magnitude of its offense." ${ }^{\prime 88}$ Those associated with the Legion perspective did not take kindly to Wyckoff's claim that it seemed highly likely that the hall had been charged before shots were fired. Wyckoff also noted that he felt that the "beginning" of the entire tragedy took place not on November 11, but in the previous summer of 1919, when the Citizen's Protective Committee first met to contemplate action against the Wobblies. As such, Wyckoff situated his report in opposition to the official collective memory framework guarded by the Legion.

\footnotetext{
${ }^{86}$ Ibid., 169.

${ }^{87}$ Ibid., 176-177. Roberts' release would be held up by the legal efforts of Warren Grimm's brother, W.H. Grimm, who contested his initial insanity defense.

${ }^{88}$ Wyckoff, 47-48.
} 
However, Wyckoff also found that the Wobblies were culpable: "their own plans of defense from inside and outside the hall made bloodshed practically certain...it resulted...not only in the loss of several lives, but also in the loss of their liberty, and closing of their hall, and the suspension of the activities of their organization. They completely frustrated their own purposes." ${ }^{199}$ Here as elsewhere Wyckoff opposed the Labor countermemory framework that the Wobblies were completely blameless. As such, The I.W.W. railed against the report because it believed that the study should have exonerated the Wobblies completely. They weren't satisfied by Wyckoff's conclusion that while the events were everyone's fault, there was something amiss that only the Wobblies were sitting in prison.

This report's release is another critical moment in the development of the collective memory about the Tragedy, and in some ways, an attribute that makes Centralia somewhat unique. Wyckoff's effort shaped the academic memory of the Centralia Tragedy. In this version of events, Legionnaires deserved blame for what transpired, and justice required them to step forward and admit it. It was highly unlikely that any of them, particularly well-known figures who went on to be county judges and state officials, would appear in court. Yet Wyckoff called for them to admit their role in the affair. This is in direct contrast to the unblemished, peaceful depiction of the martyrs remembered in the Sentinel. Wyckoff also challenged the countermemory of pro-Labor adherents. Wyckoff believed that the Wobblies and Elmer Smith needed to recognize their roles in the bloodshed. While Wyckoff held that the trial was unjust, he and those who followed him claimed that innocence was dubious at best. The Wobblies' best bet,

\footnotetext{
${ }^{89}$ Ibid., 47.
} 
probably to the chagrin of Ray Becker, would have been to admit fault, take whatever deal could be had, and work for reconciliation within the community. Wyckoff only briefly reviewed what happened to Wesley Everest, but noted the hypocrisy of the justice system in that no one was held accountable for his death. He dismissed the notion that prosecution could not have proceeded because the killers were not known and that having no prosecution created a "deadly parallel" to the harsh punishment of the Wobblies. ${ }^{90}$ This "deadly parallel" claim helps explain why the Labor countermemory has persisted until some redress was made by those curating the official memory framework, efforts to settle the understanding of the Centralia Tragedy would fail.

As will be the case in future generations, parties within and around Centralia ignored the framework Wyckoff introduced, which I refer to as the academic framework. In other collective memory scenarios, such as those detailed by Yael Zerubavel with the creation narratives of the modern Israeli state, the academic perspective is often coopted either by the official collective memory or the countermemory, whereas here, it stands apart from both. At times, those other groups will attempt to appropriate academic scholarship to bolster their case, but rarely did they succeed.

\section{Coda for the First Years}

Elmer Smith did not see the Church Report as a complete defeat and may have been influenced by its recommendations in his effort to gain the prisoners' release. He schemed that, since the men had served the minimum time for their specific conviction, maybe he could get their sentences commuted to time served because of good behavior. ${ }^{91}$ While Governor Hartley never warmed to the idea, he had grown tried of the letters and

\footnotetext{
${ }^{90}$ Ibid., 45.

${ }^{91}$ Copeland, 179.
} 
protests and public outcry over the Wobblies' imprisonment. When Smith asked for Barnett to be released after his wife had gotten cancer, Hartley relented with a six-month parole. Barnett was pardoned at the end of that stretch, and then Hartley allowed the others to follow at a trickle, assuming the good press would help him in the 1932 election. Smith would not see the end of this process, however, as he died in 1932. By 1933 only Ray Becker, who insisted that his sentence be overturned (something Hartley and his successor Clarence Martin were not going to allow), remained in prison.

Ray Becker became a separate case unto himself, and the work of Julia Godman (later Ruuttila), who served as secretary of what became the Free Ray Becker Committee, later contributed to the ongoing splintering of memory frameworks. She spent several years revisiting people connected to the case, trying to shore up support for a new trial for Becker and a congressional investigation. Several of the affidavits she collected proved useful to future researchers. Becker's fight was reported in the Labor press throughout the Northwest, keeping the Centralia case alive in cultural countermemory long after his colleagues had departed. Becker was persistently thwarted, by judges but more frequently by his own intransigence. He would go through several lawyers and committees, having fired or alienated most people who worked with him. ${ }^{92}$ Eventually Martin paroled him even though he worried Becker wanted to stay in jail. Becker accepted the parole and moved to Vancouver, Washington. He died in March of 1950. A local obituary did not

\footnotetext{
${ }^{92}$ Letter from Julia Ruuttila to Union Leader, June 1, 1937, Ray Becker Papers, Mss 2003, Folder 2/13, Oregon Historical Society Research Library.
} 
include his connection to the case, stating only that he had died of natural causes while clearing trees. $^{93}$

The first time the Centralia Tragedy appeared in academic literature was in 1954, when historian Robert Tyler published an article in the Pacific Northwest Quarterly. Its scope and conclusions were similar to the Church Report, which Tyler asserted was "moderate" in tone. 94 Tyler's tone, moderate in its own right, may have belied a sense that the history was settled and the community had moved on. There was additional evidence for this in Centralia. For example, in 1955 a local Community Development Program authored a yearbook, the History of Centralia. It tried to be as inoffensive as possible:

It was not surprising that Centralia...should have a share in the history of this class warfare.... [n this situation] violence is very likely, and the Centralia Armistice Day tragedy of 1919, in which four legionnaires were killed and three more wounded, and one I.W.W. hanged, was the direct result of this long and violent struggle, which occurred in many parts of our country during this period. $^{95}$

The follow up trial and any hint of controversy is omitted. The following paragraph discussed how the union meeting hall had been converted to a bowling alley. While this particular overview was generally accurate, its suggestion that what happened in Centralia was merely a ripple of a larger wave cast away the years of internal struggle and pain on the part of the city's inhabitants. In future generations, the glaring absence of the varied memories would be addressed by a legion of advocates and scholars from Centralia and beyond.

\footnotetext{
93 "Body Found in Clearing," newspaper excerpt marked 3-7-50. Ray Becker Papers, Mss 2003, Folder 2/24, Oregon Historical Society Research Library.

94 Robert Tyler, "Violence in Centralia, 1919," Pacific Northwest Quarterly 45, no. 4 (Oct 1954): 124.

${ }^{95}$ History of Centralia, (Centralia Community Development Program: Centralia, WA, 1955), 41.
} 


\section{Chapter 2: "Authoritative" Accounts}

In 1955, John McClelland was a fifteen-year old Washington high school student. As a youth he had heard about Armistice Day, 1919, but never quite got a full story from those who seemed to know. When he entered high school, he happened upon a "History of Centralia." Excited to finally get the full story about the Centralia Tragedy, he was disappointed when he saw that the paper included only a nondescript paragraph about it. McClelland interpreted this to mean there must have been some type of secret about the Tragedy that people were not sharing: "What shame was being concealed? What scandal was being glossed over? What really happened on up there in Centralia that day in November 1919, when the first anniversary of the armistice was observed?"1

McClelland became a journalist, newspaper publisher, historian, and founder of the Washington State Historical Society's quarterly publication, Columbia, the Magazine of Northwest History. He also wrote what American West scholar Richard Maxwell Brown termed the "authoritative" account of the Centralia Massacre. ${ }^{2}$ Wobbly War: The Centralia Story, released in 1987, is considered by some Centralians to be the capstone account of the Tragedy. It was also a labor of love, as McClelland published his first article on the topic, "Terror on Tower Avenue," in the Pacific Northwest Quarterly in 1966, twenty-one years earlier. According to Brown, McClelland "uncovered much new material" and dealt "judiciously with the numerous questions that have arisen about the outbreak of 1919."3 These questions most prominently included the initiation of violence on November 11 and the question of Everest's possible mutilation.

\footnotetext{
${ }^{1}$ John McClelland, Wobbly War. (Tacoma: Washington State Historical Society Press, 1987). xiii

${ }^{2}$ Richard Maxwell Brown, Foreword of Wobbly War. xi.

${ }^{3}$ Ibid., ix.
} 
Wobbly War has become the standard text of those who want to investigate the Centralia Tragedy. Citizens of Centralia support Brown's assertion that the text is the "authoritative" account of the Tragedy. ${ }^{4}$ At this juncture, however, I disagree with Brown and those citizens. Wobbly War, while one of the more extensive treatments of the actual day of the Tragedy, is not the authoritative account of the Tragedy, mainly because it does not encapsulate the competing frameworks effectively. In fact, it was coopted by adherents of the official collective memory framework in order to serve that framework's ongoing fight with the Labor countermemory.

This chapter chronicles the path of collective memory of the Tragedy as the various frameworks became further entrenched between approximately 1955 and 1992 . It looks at how the Centralia Chronicle, a guardian of the official memory framework and to that point unwilling to embrace other possible interpretations, used the event as recurring feature in its pages, in prompting further development of all three frameworks. Articles from this period only mention two possible frameworks - the official and a Labor-academic combination. The chapter then describes why this was an incorrect assessment. It does this by examining the unsuccessful effort of Julia Ruuttila, at one point the principal carrier of the Labor countermemory, to appropriate the academic sphere through her relationship with a young scholar, Albert Gunns. When Gunns's work disappointed Ruuttila, leading to a public confrontation between the two, it demonstrated the Labor countermemory's general incompatibility with the academic framework.

\footnotetext{
${ }^{4}$ Margaret Shields (Lewis County Museum staff member) in discussion with author, October, 2012; Bill Moeller, “A Mystery 90 Years Later: Who was Jack Davis?” Centralia Chronicle, (Centralia, WA), Nov. $10,2009$.
} 
The chapter then examines additional academic efforts, culminating in McClelland's book, which aimed to be a comprehensive academic account. It failed in this effort, although its limitations spurred official memory adherents to claim academic support for their position. These assertions are unpersuasive, and demonstrably so after reviewing the final academic book of the period, Tom Copeland's The Centralia Tragedy of 1919: Elmer Smith and the Wobblies. While that book was published during the period covered in Chapter 3, its provenance derives from the academic work described below.

\section{A New Look from the Centralia Chronicle}

The archives of the Centralia Chronicle contain few references to the Tragedy through the 1940s and 1950s. The Chronicle, which had maintained its anti-Wobbly, official memory framework stance throughout the 1920s, usually relegated the Centralia Tragedy deep within the paper. ${ }^{5}$ But in 1962, at the forty-third anniversary of the Tragedy, the Seattle Times ran a story by Associated Press reporter John Komen. Entitled "Hatred Born in Centralia Massacre Still Simmers," it upset the staff at the Chronicle so much that the editor/publisher, John B. Edinger, refused to run it. ${ }^{6}$ Yet, after the article appeared, the staff at the Chronicle felt compelled to start reporting on the Tragedy again. This time, according to former editor Brian Mittge, instead of simply reiterating what had become the mantra of the official memory framework, the paper expanded its coverage to include additional perspectives about the Tragedy. This did not signal a shift in their perspective, however. Rather, its editors and reporters saw this expansion as necessary to

\footnotetext{
${ }^{5}$ Brian Mittge, "Framing Tragedy: The Centralia Chronicle's Changing View of its 1919 Hometown “Massacre.”(University Scholars Thesis, Seattle Pacific University, 2004),18.

${ }^{6}$ Ibid, 19.
} 
combat the "untruths" spread about the community through rival frameworks of memory. ${ }^{7}$

Edinger and the paper wanted to frame "the "tragedy in a context of history that was interesting but irrelevant." ${ }^{\prime 8}$ In the early 1960s, the editors wanted the official memory to rest like the Sentinel - etched and unchanging - without any challenge from the Labor countermemory. So in November of 1963, on the forty-fourth anniversary of the Tragedy, the Chronicle ran a front page editorial, "Let's Refute 1919 Armistice Day Dishonor." It intoned, "No one asks what happened to be forgotten. What Centralia asks and deserves today is that the record remain, but without the dishonor contemporary historians insist is there. It is time to command accuracy and respect." "9

That statement is significant for two reasons. First, it flies in the face of anyone who suggests that Centralia was guarding a "secret" about the Tragedy. For clarification, when anyone writes about there being a "secret" in Centralia, there are two things they are usually referring to. The first, alluded to by McClelland and mentioned above, is that the town of Centralia, as a whole, does not talk about the Centralia Tragedy and the 1919 event is entirely covered up. This is simply untrue. Adherents of the official memory framework frequently commented on the Tragedy and there had been ample documentation of it. ${ }^{10}$ The sheer volume of materials about the Tragedy, from 1920 until the present, is staggering for an incident of its scope. What has happened is that claims of silence and secrecy about the Tragedy generally are confused with the fact that those

\footnotetext{
${ }^{7}$ Ibid. Mittge surmised this by examining copies of the Times article in the Chronicle archives that included notes and highlights around key passages, most notably a segment that referenced an unnamed local businessman who claimed that Centralia "never recovered" from the fallout of the massacre ${ }^{8}$ Ibid.

9 “Let's Refute 1919 Armistice Day Dishonor." Centralia Chronicle, (Centralia, WA), Nov. 11, 1963.

${ }^{10}$ Tom Copeland, Wesley Everest: I.W.W. Martyr." Pacific Northwest Quarterly, 77, no..4 (1986): 122-

123. Copeland estimated that over 45 works had been completed about the event.
} 
men who lynched Wesley Everest are still unknown. To Labor countermemory adherents, that is the secret that is being actively guarded by the official memory carriers, and the reason that the story of Centralia needs to be continually retold until those who perpetrated the atrocity against Everest are brought to justice.

The second reason that the comment is significant is the claim that "contemporary historians" were insisting on dishonor. Up this this point there had been very few academic treatments of the Tragedy. ${ }^{11}$

\section{The radical and the academic}

The Chronicle was mistaken about an alignment between the Labor countermemory and the academic memory, as these two frameworks were split pretty even by the early 1960s. This division is exemplified by the experience of Albert Gunns, a young scholar working on a history of the American Civil Liberties Union (ACLU) in the early 1960s. A doctoral student at the University of Washington, Gunns discovered the ACLU's founder Roger Baldwin's relationship with Centralia figures such as Elmer Smith and Ray Becker. Baldwin had worked with Elmer Smith while barnstorming throughout the Pacific Northwest and sought legal representation for Smith when he was disbarred. ${ }^{12}$ Likewise, when Becker needed representation, the ACLU aided him. Getting materials from Smith and Becker, however, was an issue for Gunns, as both were dead and the location of their papers was unknown. Gunns learned that Julia Ruuttila had many; she had inherited most of Smith's files pertaining to Becker. She also held most of

\footnotetext{
${ }^{11}$ So far in this thesis I have mentioned the work of DeWitte Wyckoff, who published a report that technically was not an academic treatment, even if I group it as such, and Robert Tyler's 1954 article. It is thus intriguing to see that the Chronicle believed that individuals like these were insisting the history was dishonorable, when in earnest that challenge was coming from a different front.

${ }^{12}$ Tom Copeland, The Centralia Tragedy of 1919: Elmer Smith and the Wobblies, (Seattle: University of Washington Press, 1995), 132-135, 137.
} 
the archival material from the Free Becker Committee, of which she had served as Treasurer and a principal agent for garnering affidavits in Centralia. Gunns contacted Ruuttila in the spring of 1964 and asked if she would share them.

Ruuttila, who died in 1991, remained fervently pro-Labor throughout her entire life. She had written extensively in the Labor press about Ray Becker and the Centralia Tragedy. She believed the Wobblies were within their rights to open fire on the Legionnaires and that their imprisonment while the murderers of Wesley Everest were still free was a gross miscarriage of justice. ${ }^{13}$ Initially she was excited about helping Gunns work on his ACLU paper. As a requirement for sharing her materials, she requested that Gunns craft a short academic work on the Centralia Tragedy as well. Ruuttila was hoping for a fresh perspective on the Tragedy, one in which academic support would buttress the Labor countermemory framework. Considering Gunns's research interest on the ACLU, she felt he would be more sympathetic than Tyler or Wyckoff. ${ }^{14}$ Gunns agreed to the exchange and got Ruuttila's papers to the University of Washington. ${ }^{15}$

It took Gunns some time to complete a standalone work on the Tragedy. Between 1964 and the work's completion, there were few exchanges in which Ruuttila politely asked Gunns about his work, particularly how long before he would complete it. Gunns had interviewed Ruuttila twice, meeting her in both Portland and Astoria, Oregon, along with other archival research. He presented a conference paper on the Tragedy at the 1967

\footnotetext{
${ }^{13}$ Sandy Polishuk (Oral historian, Ruuttila biographer), in discussion with author, June 10, 2014.

${ }^{14}$ Albert Gunns, email message to author. June 5, 2014. Gunns confirmed that this was what Ruuttila had sought.

${ }^{15}$ Letter from Julia Ruuttila to Al Gunns, May 27, 1964. Ray Becker papers, Mss 2003, Oregon Historical Society Research Library.
} 
Pacific Northwest History Conference in Tacoma, which he published in the Pacific Northwest Quarterly a year later. ${ }^{16}$

Gunns's article, "Ray Becker, the Last Centralia Prisoner," was one of two academic articles to appear in the late 1960s about Centralia. In it, Gunns focused on the lengthy effort to gain Becker's release from prison. His major conclusion was that gaining Becker's release was exceptionally complicated, partly because of political issues in Washington State but mainly because Becker was uncooperative. Gunns, who later identified himself as "green and naïve" at the time, felt that he was trying simply to do what historians do when he concluded: "Becker undeniably compounded the cost by choosing to stand on principle - as he defined it - when he could have otherwise had his freedom." ${ }^{17}$ Further, Gunns noted that the Free Ray Becker Committee was not as successful as it claimed and that other groups, like the ACLU, were just as instrumental in Becker's release. In his analysis, the fact that Becker was released without an apology, or "release without vindication," was “intellectually unsatisfactory."18

The article complemented what had been published up to that point on Centralia. It focused on the lengthy process of securing Becker's release, devoting attention to the players fighting the Washington State government. For those who had read Tyler, Gunns's article was a worthy addition to the academic literature. For the first time, readers learned of the range of Smith's efforts to free the prisoners, as well as the

\footnotetext{
${ }^{16}$ Letter from Richard Berner to Julia Ruuttila, March 20, 1967. Ray Becker papers, Mss 2003, Oregon Historical Society Research Library. Ruuttila was invited to the conference by Richard C. Berner in March of 1967, as part of asking for permanent ownership of the collection.

${ }^{17}$ Albert Gunns, "Ray Becker, the Last Centralia Prisoner," Pacific Northwest Quarterly 59, no. 2, (1968): 99.

${ }^{18}$ Ibid., 99. This notion of “intellectually unsatisfactory” isn't clearly defined in the article. From the tenor of the piece, it seems that the release did not offer pro-Labor sympathizers any form of victory, moral or real that they could celebrate.
} 
challenges that the Centralia Publicity Committee faced working within the legal system. Readers also learned more about the lives of the prisoners in jail and their despair about the length of their stay in the Walla Walla penitentiary. Most poignant was the depiction of Ray Becker, whom Gunns humanized in good and bad ways. On one level, Becker's devotion to poring over court documents and developing a working knowledge of the law is inspirational. On the other, Becker's frequent clashes with governors, parole boards, and supporters cast him in a negative light. Gunns faulted Becker for his protracted stay in prison and argued that his release, which could have been momentous, was much less so because of his manner. ${ }^{19}$

Ruuttila was not pleased with Gunns' article. She made this clear when Gunns sent her a draft. On one level, his reluctance to delve into Tragedy issues upset her, most likely because he refused to conclude that the Legionnaires were the first aggressors. Ruuttila wrote, "I find it hard to believe if you had gone over the documents to which you had access through our files you could have come out with this statement...the crucial question of who had made the first move... was never answered. ${ }^{20}$ She proceeded to pick the article apart, challenging Gunns' unwillingness to use statements from 1936 affidavits and his failure to mention people like Ray Becker committee member E.B. Weber, to whom she believed, the article, "failed to do justice." ${ }^{, 1}$ Ruuttila was likely most upset that Gunns gave any credit to the ACLU, in that she believed the Committee was far more active and responsible for the release. ${ }^{22}$

\footnotetext{
${ }^{19}$ Ibid., 99.

${ }^{20}$ Letter from Julia Ruuttila to Albert Gunns, March 5, 1967. Ray Becker papers, Mss 2003, Oregon Historical Society Research Library.

21 Ibid.

${ }^{22}$ Sandy Polishuk (oral historian, Ruuttila biographer), in discussion with author, June 10, 2014.
} 
I also feel any comprehensive use of the material tumed over to the University by the FRBC would have indicated a necessity for mentioning that other documents showing sub mation of perjury -- in one case the signed a dmission of perjury on the part of a second prosecution witness -- a member of the Washingtin legislature at the time ho made the affidavit, no less -were in those files.

I can't help foeling, also, that your article fails to do justice to the efforts of two persons who were very active in Becker's behalf -- S. P. Stevens, chalrman of the FRBC (now dead), and E. B. Weber, committee treasurer. Both of these men made numerous trips to Walla Walla to confer with Ray, and both were extremely influential in enlisting union support for the case.

You mention that friends who read your draft felt you had done little to describe Becker's personality or to explain why he held out so long and then left prison without "making a fuss". That, of course, is the very heart of my own criticism. The protagonist is a shadowy figure, the magnificent struggle of so many poople, over so many years, to free Becker never really "comes alive". We see Mrs. Farquharson of the ACLU having her "chatty" little talks with Governor Martin. (Did they drink tea together?) We never see the woodworkers buying the Free Ray Bocker buttons and the horse hair belts - or the man who had spent 20 years in a stone cell making that prodigious sffort to walk up the aisle to the mike in the IWA hall in Portland, after his release

One finishes your article, wondering "What was it all about? What was accomplished?" But it wasn't that way, at all.

I telephoned Mr. Weber before starting this letter, and he authorized me $t$; say he, tor, was very disappointed in your treatment of the case.

I'll say one thing, though, your footnoting was out nf this world. And I do realize you have done a great deal of work

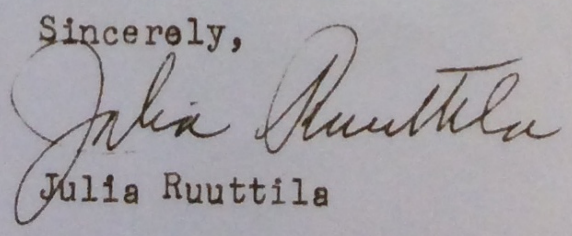

Fig. 7. Final page of letter from Julia Ruuttila to Albert Gunns, March 5, 1967, Ray Becker Papers, Mss 2003, Oregon Historical Society Research Library. 
Ruuttila also felt that Gunns had failed to adequately explain Becker's intransigence. While she granted that readers learned more about him than they had known previously, she felt that Becker's stubbornness about release needed more explanation. Ruuttila argued that she was not alone on that point, as Gunns had found that criticism elsewhere. ${ }^{23}$ Ultimately, Ruuttila was simply "disappointed" with the article, an opinion that she shared with Weber. Her disappointment became vocal when Gunns spoke at the $60^{\text {th }}$ Anniversary conference on the Tragedy in Centralia and Montesano. Gunns recalled, "She called me a liar and attacked me so vehemently from the floor that I'm afraid I reacted with just shocked silence and just let her go on." ${ }^{24}$ Ruuttila biographer Sandy Polishuk related that Ruuttila went up to the dais, announced that she was "sick of this academic bullshit," and proceeded to blast away at Gunns. ${ }^{25}$

The Ruuttila-Gunns confrontation exposed the rift between the Labor countermemory and the academic frameworks of the Centralia Tragedy. While the Chronicle had identified these two frameworks as one and the same, the opposite was true. Ruuttila's personal connection to the case and lifetime support of labor and I.W.W. causes made her understanding of the Centralia Tragedy one where justice had never been served. Ruuttila was not an academic and did not care for the academic perspective

\footnotetext{
${ }^{23}$ Letter from Julia Ruuttila to Albert Gunns, March 5, 1967. In Ruuttila's letter she references what Gunns must have written in an earlier letter about how other readers felt that Becker was not fully characterized. Part of Ruuttila's frustration may have come from the fact that she had a closer connection to Becker, had completed two separate oral histories with Gunns, and yet Gunns did not spend enough time referencing Becker in his work.

${ }^{24}$ Albert Gunns, email to author, June 5, 2014.

${ }^{25}$ Sandy Polishuk (oral historian, Ruuttila biographer), in discussion with author, June 10, 2014. Polishuk related that Dick Moore of the ILWU had shared this story as she had been writing a book on Ruuttila. A version of this story is also noted in an article by Shelby Scates, "Killing Time in Centralia," Seattle PostIntelligencer (Seattle, WA), November 18, 1979.
} 
when it failed to insist on exoneration of the Wobblies. ${ }^{26}$ Ruuttila's position thus is important to understanding the further development of the Labor countermemory, as she played a pivotal role in nurturing it when no one else was actively doing so. She also was influential in espousing the Labor countermemory's divergence with the historical record and its insistence that the Wobblies were blameless, elements visible today in work by Anne Fischel and contemporary Wobblies. Driven by her close relationship with Becker she was determined to see that the Centralia prisoners received public exoneration and could not accept the possibility that Becker was even in part responsible for his sustained imprisonment. ${ }^{27}$

Gunns also represents an important figure in the Centralia Tragedy story. Gunns did not take many chances in this early work, and he generally sustained what Tyler had written in 1954. While Gunns added to the discussion in his description of Becker and the effort to overturn his conviction, he did not change the substance of the academic framework of the Tragedy. A young scholar, Gunns, stuck to his sources and did not venture far beyond them. He certainly was not going to claim that the affidavits had much weight. Moreover, since the ACLU, and not Centralia, was his primary focus, he simply was not going to examine the Centralia case in the way that Ruuttila wanted, since interrogating people like original trial prosecutor C.D. Cunningham was not necessarily germane to his central thesis. ${ }^{28}$ Given Gunns' proximity to Ruuttila, his commitment to interviewing her and capturing her version of events, as well as his debt to her for access

\footnotetext{
${ }^{26}$ Ibid.

${ }^{27}$ In my own analysis of her letters, it is evident that she devoted years of her life to this effort to free Becker, and the suggestion that she did not have more agency in the process of freeing him sincerely hurt her and caused her to be more proactive in the curation of the Labor countermemory.

${ }^{28}$ Albert Gunns, email message to author, June 5, 2014. Gunns apparently did interview Cunningham prior to a 1979 commemoration in Centralia, but not prior to the 1968 article.
} 
to previously unavailable sources, it is striking that he still situated the history along the same lines as Wyckoff and Tyler.

To Ruuttila's consternation, Gunns developed enough of a reputation from his article that he was asked to keynote the 1979 Centralia conference and write the foreword to Tom Copeland's book. Throughout, Gunns maintained the logic of his 1960s article, situating the academic perspective on Centralia outside both of the official and Labor countermemory frameworks. At the 1968 Tacoma conference, his first time presenting on this topic, he set out to explain legal strategies in the trial rather than offer conclusions about the Tragedy itself. Even though he was speaking to a Labor history group in 1979, his academic take was removed enough to stir Ruuttila to interrupt. When I communicated with Gunns for this thesis, he related that he earnestly believed the Wobblies were "screwed" and got a really bad deal. He simply felt he could not prove that with the available academic resources, and consequently was not going to state otherwise, in academic writing or presentations. Gunns indicated that he regretted not arguing with Ruuttila at the 1979 conference. He explained that part of the reason he did not was shock, in that he did not know how to respond. But on another level, he indicated that arguing with Ruuttila might not have been productive. He was probably correct in that assumption, given the distance between the narratives and the fact that they lacked a common vocabulary; their frameworks were in direct conflict of each other. ${ }^{29}$

\section{Countermemory's Academic Veneer}

Ruuttila ended up depositing the Free Ray Becker Committee files at the Oregon Historical Society rather than the University of Washington. In the early 1970s OHS

\footnotetext{
${ }^{29}$ Ibid.
} 
staff member Lawrence Skoog discovered them and began to work on the Centralia Tragedy. Skoog's first publication on Centralia was a review of a series of

$$
\text { Centralia Massaere, } 1919
$$

PACIFIC NORTHWEST LABOR HISTORY ASSOCIATION

presents a

60th ANNIVERSARY COMMEMORATIVE TOUR

of the

\section{CENTRALIA MASSACRE}

NOVEMBER 11, 1979

PROGRAM

\begin{tabular}{|c|c|}
\hline Montesano Court House & Noon \\
\hline Lunch - No Host - Union House & \\
\hline Hangman's Bridge - Centralia & 3 p.m. \\
\hline Centralia Tour/Talk & \\
\hline Dinner & 5 p.m. \\
\hline Commemorative Ceremony & 7 p.m. \\
\hline
\end{tabular}

\section{Travel by Greyhound Charter}

From Seattle: 9:00 a.m., 2700 - 1st Ave.

From Portland: 8:45 a.m., Marylhurst (Parking Provided)

\$15 PER PERSON

MAKE YOUR RESERVATION NOW

In Seattle: PNLHA, P.O. Box 25048, Northgate Station, Seattle, 98125

In Portland, PNLC, Attn.: J. Lembcke, Marylhurst, Oregon 97036

Fig. 8. Booklet from the PNLHA Centralia Conference, 1979,

Kirk Library Centralia Massacre digital collection, http:/centralia.sdlhost.com/\#/item/000000011043062/view

(accessed July 1, 2015). 
pamphlets about the Tragedy. ${ }^{30}$ A few years later Skoog completed a Master's Thesis at Portland State University on the affidavits in the Free Ray Becker collection. Skoog examined the affidavits as "a kind of oral history" of the full Centralia story. ${ }^{31}$ Skoog was one of the first to examine a broader collection of voices in academic writing. Yet, in doing so, Skoog complicated the memory frameworks. Since he produced some academic work, it could be easy to align him with the other academics mentioned thus far. But Skoog never provided a satisfactory explanation of the significance of the affidavits. His failure to justify their inclusion separates Skoog from the academic memory framework. He instead represents a transitional moment for the Labor countermemory. Following Skoog's example, work from non-historical yet academic disciplines begins to bolster the Labor countermemory framework, giving it the veneer of academic support.

Eleanor Walden, a University of California, Berkeley, Master's student in Folklore who started a thesis on Centralia, further applied this sheen in the late-1970s. Walden identified herself as an activist, and saw her thesis as both a paper about the massacre and a documentary. In an ad posted in the Labor paper, Industrial Worker, she explained that she knew a "Will Hudson" from Pathe News who had made a complete film of November 11, 1919. She claimed that the "Defense Committee" had attempted to use the film, but the only remaining footage was a "spliced strip from which all record

\footnotetext{
${ }^{30}$ Lawrence Skoog, "The Centralia Case: Three Views of the Armistice Day Tragedy at Centralia, Washington, Nov. 11, 1919. “ Oregon Historical Quarterly 73, no. 1 (1972): 70-71. I have not be able to track down why DeCapo Press decided to release a bound series of these pamphlets at this time, seeing that there was no official commemoration in 1969.

${ }^{31}$ Lawrence Skoog, "Labor Violence: The Centralia Case, the IWW, and its Enemies,"(master's thesis, Portland State University, 1975), 4. Skoog later penned a book about the incident, Centralia, 1919 in 1978.
} 
of the confrontation... has been deleted. ${ }^{32}$ She requested information from anyone who knew about the film, or who had "personal experience." Walden initially sought to study the film's story, but when no additional material surfaced, she turned to anyone willing to discuss Centralia with her.

Many of the people whom Walden interviewed had connections to the Tragedy Wobblies who were imprisoned as a result of the crackdown like Joe Murphy, or children who were on the street watching the parade when shots rang out. Her oral history work is significant for the way in which it drew out Centralians' recollections of the event. In a way, it built on Skoog's call to incorporate these voices, and did it more directly than Skoog's emphasis on the affidavits. While for many those memories were colored by stories from parents or relatives, or articles in Chronicle, the range of the recollections is astounding. As an interviewer Walden rarely says much, yet her interviewees quickly and expansively relate details of the Tragedy as they experienced it personally or encountered it through conversation. ${ }^{33}$

Walden recorded oral histories with several key figures in Tragedy history, most importantly Edward Coll, the American Legionnaire who in the late 1920s was instrumental in drawing attention to the unfairness of the trial through his work with Elmer Smith. Coll recalled many conversations, such as his meeting with C.D. Cunningham, and his work with Elmer Smith. He remembered his initial interest in the

\footnotetext{
${ }^{32}$ Walden is one of the first people to name the Pathe photographer in recent history. Interestingly, a letter from George Vanderveer and Elmer Smith from April 7,1924 to a Mr. John Beffel comments on a March, 1924 article by Ralph Chaplin in the Industrial Pioneer claiming that there was a photographer at Centralia. Both Vanderveer and Smith claim in the letter that they believe the notion of a photographer being at Centralia was "pure myth." Complicating this is a series of online clips that have recently emerged that are referred to as Centralia films but cannot be corroborated as such.

${ }^{33}$ Edward Coll, interview by Elizabeth Walden, June 26, 1979, http://centralia.sdlhost.com/\#/item/000000011042870/view (accessed on June 5, 2014).
} 
Tragedy, stemming primarily from his conversation with people who told him emphatically that they would "never step foot in a Legion Hall" because of what had happened in Centralia.

Walden's thesis plan presented a counterpoint to previous academic work. Unlike Gunns, who was writing to produce an "objective" picture, Walden, a folklorist, conducted her interviews with an eye toward proving the Wobblies were framed. She defined her efforts as "ethnographic rather than historic" and focused her attention on pro-Wobbly figures. She rarely included conversations with those who were predisposed toward the Legionnaires. ${ }^{34}$

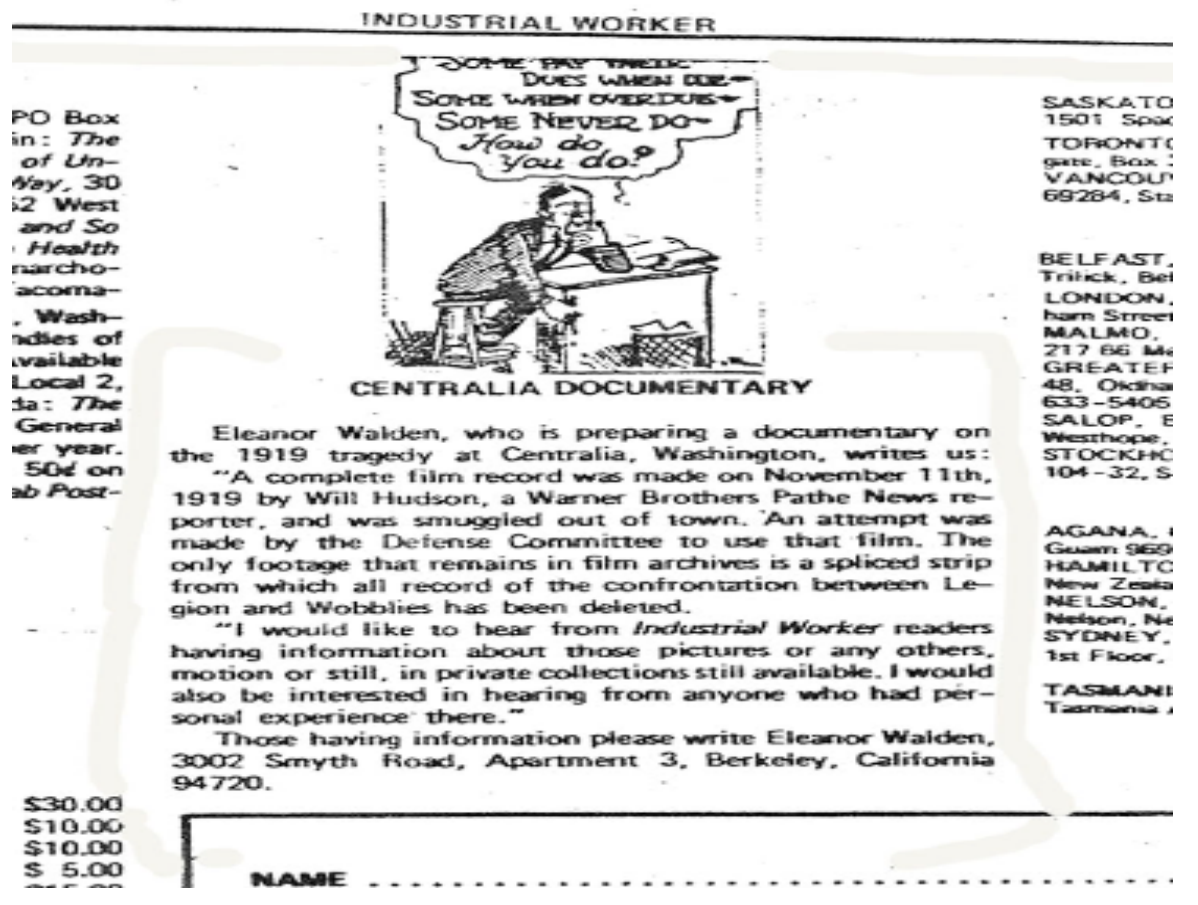

Fig. 9. Eleanor Walden, Advertisement, 1979, from the June edition of the Industrial Worker, Kirk Library Centralia Massacre digital collection, http://centralia.sdlhost.com/\#item/000000011041642/about (accessed July 1, 2015).

\footnotetext{
${ }^{34}$ Eleanor Walden, “A Wob Remembers,” Eleanor Walden Papers, Centralia College, Kirk Library, Box 5, Folder 5.3.
} 
This is even more evident in Walden's plan for her documentary, detailed in a four-page prospectus, "A Wob Remembers," that she donated to the Centralia College Library in 2009. Working with an aged former Wobbly, Joe Murphy, she was going to film him "in Centralia today as he remembers his experiences there 60 years ago." ${ }^{35}$ The fact that Murphy did not appear in any previous historical literature on the Tragedy, this didn't seem to bother Walden. She noted that her film would "not claim to be a historical documentary but an oral history illumined by subjectivity, value judgment, memory and identification with principles shared by a group of men and women calling themselves radical. ${ }^{36}$ Due to a disagreement with the two fellow graduate students that she had commissioned to shoot the footage, the film that Walden took in Centralia was never compiled into her planned documentary. ${ }^{37}$ Eventually, the film ended up with Joe Murphy's wife in the San Francisco Bay area, where it was supposed to be given to archives at San Francisco State University. Instead, Murphy's wife forgot about the film after putting it in her basement, and bugs and rats destroyed it. ${ }^{38}$

Walden's willingness to depart from the historical record and opt for a folkloric approach to the Tragedy places her in the same category as Skoog. She aimed at linking the Wobblies to other folk figures in American history and Centralia was going to be her frame for producing that vision, treating the I.W.W. as akin to "Paul Bunyon." ${ }^{, 39}$ She later claimed that "as a folklorist, I am interested in how people make sense of their lives, and

\footnotetext{
${ }^{35}$ Ibid.

${ }^{36}$ Ibid.

${ }^{37}$ Robin Updike, "Master's project leads to a lawsuit." Northeast Bay Independent and Gazette. June 17, 1980. This lawsuit was not about content matter, but about service agreements about the workload between the students involved and Walden.

${ }_{30}^{38}$ Eleanor Walden (folklorist, activist), in discussion with author, May 21, 2015.

${ }^{39}$ Walden, "A Wob Remembers."
} 
by taking a side [in the Tragedy] it gives me a place to stand. ${ }^{, 40}$ As a folklorist, this was a legitimate, although, because much of her work resembles academic history, the Labor countermemory effectively appropriated it. When Walden gave her work to the Kirk Library in 2009, the staff simply appended her materials to their Tragedy collection. The Kirk Library provides no disclaimer about Walden's perspective, which is troubling because that the collection integrates her folkloric work with the academic historical work that preceded it. ${ }^{41}$

This presentation does not claim to be a historical documentary but an oral history illumined by subjectivity, value judgement, memory, and identification with principles shared by a group of men and women calling themselves radicals. As such it deserves the title of ethnographic rather than historical documentation.

\section{The treatment}

The subjective experience of one man's life as an integral part of the historical events that surrounded him will be the central theme of this project. Joe Murphy - Wobbly - will be featured through his remembrances of events, people, places, and his understanding of them.

The visual experience will be created through the juxtaposition of Centralia as it is today and the visual record of it circa 1919. I will utilize any available motion picture footage, still photographs, and shoot new live action footage to be

November 9,2009, retyped for digitization from a photocopy in the possession of the Kirk Library, Centralia College, Centralia, Washington. This paper was written by Eleanor Walden, a student at the University of California, Los Angeles in 1979.

Fig. 10. Eleanor Walden, Selection from “A Wob Remembers,” 1979, Kirk Library Centralia Massacre digital collection, http://centralia.sdlhost.com/\#/item/000000011041940/view, (accessed July 1, 2015)

\footnotetext{
${ }^{40}$ Eleanor Walden (folklorist, activist), in discussion with author, May 21, 2015.

${ }^{41}$ Eleanor Walden, Centralia Massacre Slideshow, http://centralia.sdlhost.com/\#/item/000000011042851/view (accessed July 1, 2015). Some scholars might not find this intermingling to be problematic. Because of the convoluted nature of the Tragedy story, I am more concerned that the introduction of the Walden materials, sans disclaimer, complicates those wanting to do academic work on the Tragedy.
} 
Walden's course echoes what both Pierre Nora and Yael Zerubavel have argued about collective memory. As Zerubavel observed about Israeli creation narratives, Walden's planned documentary disregarded the facts of the Tragedy in service to the countermemory legend of the I.W.W. Similar to the other proponents of the Labor countermemory framework, Walden absorbed what she found useful from her folkloric work, but was less concerned with its objective historicity.

\section{McClelland and Copeland}

The mid-1980s saw the development of two major works about the Centralia Tragedy. To which collective memory framework they belong is debatable. John McClelland, who as a young student was curious why the story was reduced to whispers and a paragraph in a history of the town, authored the first, Wobbly War (1987). Minnesota journalist Tom Copeland wrote the other, The Centralia Tragedy: Elmer Smith and the Wobblies (1992). The two texts in some cases are parallel treatments of the event - with material assembled from archival work (McClelland) or masterful interviews (Copeland). Their writing was professional and crisp and they presented the events of the Tragedy with an eye for detail. Professional historians lauded both works in their respective forewords -- McClelland by Brown, Copeland by Gunns.

Both books have limitations. Copeland was a sophomore at Macalester College in Minnesota, Smith's alma mater, when a history professor put a tape recorder in his hands and urged him to interview Smith's surviving classmates. ${ }^{42}$ His interest in Centralia began and ended with Smith, a famed alumnus at Macalester. Copeland's story

\footnotetext{
${ }^{42}$ Copeland, xiii.
} 
thus offered a trove of information about Smith's experience, although the reader might wish that he had expanded the primary narrative. By comparison, McClelland sought a more comprehensive work on the Tragedy. Both works blurred the lines between the various frameworks. Neither man was a professional historian (so unsurprisingly neither book necessarily abides by the academic framework of the Tragedy). Copeland effort's though comes closer to historical analysis, as it doesn't avoid criticizing its subject. Almost immediately in his book, Copeland described Elmer Smith as "a man of many weaknesses" with a "rigid sense of morality" that "caused him to have little regard for the consequences of his actions for himself or his family." ${ }^{, 43}$ Copeland combined this unflinching historical criticism within a vivid narrative, and because of this, produced a work worthy of the academic framework.

McClelland's book presents itself as an academic work but falls short since it lacks the same analytical eye. Because of this, though, it earned widespread acceptance by those who upheld the official collective memory framework of Centralia. ${ }^{44}$ The adherents' widespread acceptance of McClelland's work, particularly after their rejection of many prior academic accounts, requires investigation.

\section{McClelland's War}

McClelland's first publication on the Tragedy appeared in the Pacific Northwest Quarterly in 1966. He had started corresponding with former Wobbly Eugene Barnett in 1960 and his article, “Terror on Tower Avenue,” predated Gunns' article on Ray Becker by two years. McClelland had presented a version of the article at the Western Historical

\footnotetext{
${ }^{43}$ Copeland, 6.

${ }^{44}$ Margaret Shields (Lewis County Museum staff), in discussion with author, October 2012.
} 
Association conference in 1965, and while it is a lucid summary of the Centralia story, it didn't add much to the body of knowledge on the Tragedy. ${ }^{45}$

McClelland's one contribution is in his explanation of how victims on both sides had become martyrs. About the Wobblies, McClelland commented, "as the years went by, the convicted men became labor martyrs. Some of the later literature identifies them only as labor prisoners, failing to mention their I.W.W. affiliation at all." ${ }^{, 46}$ Here, McClelland highlighted a key transmutation of the Centralia story within the Labor countermemory framework, how in the cases of Ruuttila and Walden, Wobbly prisoners had become symbols of “Labor.” McClelland didn't follow up on this insight in his book, however.

Wobbly War operated on a plane similar to “Terror on Tower Avenue," except that McClelland delved further into the context and aftermath of the Tragedy. He did not open much new ground. A reader familiar with the 1930 Church Report would have reached the same conclusions as found in reading the first thirty-one chapters of the book. Despite McClelland's proximity to many of the key individuals and families involved in the events, his extensive bibliography only includes a few oral histories; instead he relied on documents that had been utilized by others. The one significant exception is his examination of Eugene Barnett, which contributed to a fascinating story in his best chapter, the thirty-second, about the aftermath of Ray Becker's release.

In that chapter McClelland focused on the experiences of Centralia, both individual and communal, after Becker was released from prison in the late 1930s. He

\footnotetext{
${ }^{45}$ It should probably also be noted that his piece has very few (7) citations in the entire article, all from previously mined materials.

${ }^{46}$ John McClelland, “Terror on Tower Avenue.” Pacific Northwest Quarterly 57, no. 2 (1966): 72. McClelland does not, in this segment, identify what "later literature" he is referring to.
} 
explained the brevity of the 1954-5 Centralia Development Commission entry on the massacre. It turned out that a University of Washington researcher, Frank Anderson, attempted to cover the Tragedy, but was rebuffed by every civic institution from which he sought information. Consequently, Anderson crafted the short non-descript paragraph. As McClelland remarked, "thus the one event which brought fame to Centralia, however unwelcome it was, received bare mention in its local history." ${ }^{47}$ This was important to McClelland, as it facilitated his belief in Centralia's "secret." Yet at the same time, McClelland doesn't explain why Anderson met with such difficulty nor does he consider that Centralia has other history (which is evident in that yearbook) that a Development Commission might have preferred to sell.

Chapter 32 did include updates on key individuals in the Centralia case. ${ }^{48}$ The reader learned that Loren Roberts was still in contact with Britt Smith in the 1960s, even leading McClelland to chat with him. ${ }^{49}$ McClelland also related a story of Barnett's return to Centralia several years after his release. There, Barnett confronted William Scales, the former American Legion commander who apparently could have, but didn't, provide the Montesano court with an alibi for Barnett. The exchange McClelland noted was haunting. Barnett asked Scales if he remembered him. Scales apologized and explained that

\footnotetext{
${ }^{47}$ McClelland, Wobbly War, 234.

${ }^{48}$ Ibid., 233, 236. McClelland included a substantive bit on Vanderveer and Cunningham, although what he had culled on Vanderveer came from major media and a 1950s biography. The "Counsel for the Damned," as Vanderveer's biography deemed him, descended into divorce and alcoholism by the end of his life. Meanwhile Cunningham, who never attained the same fame as Vanderveer, was revealed by McClelland to be a caring father who stayed committed to the notion that no Legionnaires did anything wrong on Armistice Day, Cunningham would write into the American Legion Magazine to complain that for 30 years that had been constant misinformation about the Centralia Massacre. He was responding approvingly to an article that talked about the incident and which was by most historians' accounts quite removed from any notion of accuracy.

${ }^{49}$ Ibid., 233. Roberts was worried that publicity about the case would result in his losing his gun collection while Smith opined that the Hall may not have been worth defending.
} 
afterwards he tried to get Barnett released. Barnett's walked away from Scales (who was dying of cancer), gesturing "too little, too late."50 The anecdote is likely apocryphal as McClelland gleaned it from a Barnett letter and Barnett was a good storyteller. But even if it was fiction McClelland missed an opportunity for interpretation. In his telling, the two sides of the Centralia Tragedy met up and instead of any resolution (an apology, an understanding, a shootout) they simply parted. ${ }^{51}$

McClelland recounted (but never analyzed) the story of Jackie Morgan, a local worker at the Lewis County Historical Society. When, in 1981, she studied the Tragedy, the board of the Society asked her to stop. McClelland simply saw Morgan's experience as a continuation of Anderson's in the 1950s, in that the community of Centralia was perpetuating the notion that the Tragedy as a whole was a secret and not to be discussed. ${ }^{52}$ In the years immediately prior to 1981 there had been additional emphases on the Centralia Tragedy not already mentioned in this thesis. A University of Washington student, Barry Pritchard, wrote a musical, Centralia, 1919, that was performed at the School of Drama in 1976. Further, Thomas Churchill published a 213page novelization, Centralia Dead March, which blended elements of fiction and primary source materials. ${ }^{53}$ Since neither of these works depicted the official memory framework in a positive light, Morgan's efforts could have been perceived as being in this same vein and have been rejected. McClelland does not venture a guess, however, in Wobbly War.

\footnotetext{
${ }^{50}$ Ibid., 232.

${ }^{51}$ Ibid., 232-233.

${ }^{52}$ Ibid., 235. Again, while McClelland hints there was a secret to be protected here, there is also ample evidence in the 1970s of work on the Tragedy. McClelland does not examine the rationale of the museum as to why it redirected Morgan's work. In 1994, the $75^{\text {th }}$ anniversary of the Tragedy, the Museum did present an exhibit, at which McClelland was the keynote speaker.

53 . Wayne Johnson, "Centralia, 1919 tells grim story of massacre," Seattle Times (Seattle, WA), October 27, 1976; Thomas Churchill, Centralia Dead March (Willimantic, CT: Curbstone Press, 1980).
} 
McClelland also commented on the poor treatment that Everest had received in history, noting that he had not become an I.W.W. martyr like Joe Hill. Yet again, he did not address what factors contributed to Everest's lackluster appeal. Unlike Gunns, who explained that Ray Becker's release lacked the same momentum as other Wobbly prisoners because of his intransigence, McClelland did not examine why the Labor countermemory had not championed Everest. Instead, he makes quick reference to how I.W.W. hero Joe Hill had advocacy groups like the "Friends of Joe Hill" while Everest was forgotten. He could have used the opportunity to see how the Labor countermemory, as carried by Ruuttila, had focused more on the surviving Wobblies, like Becker, to carry their banner, as opposed to emphasizing someone like Everest who was arguably too tarnished by the official framework's representation. ${ }^{54}$

In McClelland's final chapter, he moved to some interpretation. However, instead of focusing on Centralia specifically he discussed the ways in which Centralia was one of several battles fought in the West Coast war against the Wobblies. One reviewer, Craig Wollner, was intrigued by this but noted that McClelland's choice of anecdotes "seem to argue both ways [pro-Wobbly and pro-Legionnaire] with no real effect." ${ }^{35}$ Wollner further explained that McClelland "shortchanged his readers and himself in ways that prevent Wobbly War from being a fully realized work. ${ }^{, 56}$ Wollner suggested that McClelland should have used the framework that Wyckoff had built in the 1930 Church Report and analyzed how the Legion had its patriotism manipulated by Timber operators.

\footnotetext{
${ }^{54}$ Ibid., 236-7.

${ }^{55}$ Craig Wollner, "Wobbly War: The Centralia Story", Oregon Historical Quarterly 89, no. 3, 1988: 307.

${ }^{56}$ Ibid. 306.
} 
Wollner concluded: "the Centralia Massacre still awaits the touch of a comprehensively interpretive intelligence." 57

It is also interesting that McClelland did not link the repression of the first Red Scare with the fear mongering of the Second. Organized labor was again assailed in the 1950s during the hysteria surrounding the Congressional hearings led by Senator Joseph McCarthy. While there is evidence that the people of Centralia were simply tired of the Tragedy narratives when McClelland first heard about the event, it is also possible that the citizens of Centralia avoided talking about the Tragedy for fear of being accused of domestic subversion. Because of their lived experience with the violent repression of the 1910 s and 1920s, it is not far-fetched to think that Centralians, particularly those who allied with the Labor countermemory framework, did not want to be considered "traitor[s] from within.",58

It is thus difficult to agree with Brown's assertion that McClelland's text is the "authoritative" account of the Centralia Tragedy, and equally troubling that Centralia citizens conceive it as such. What Wollner related and what citizens may have appreciated was that McClelland, in the end, did not pass judgment on the people of Centralia, something that the Wyckoff report had done fifty years earlier. Instead, McClelland did the exact opposite; he distilled the blame by noting that fully virtuous nor villainous people were not found. McClelland's forgiving presentation was soothing -

\footnotetext{
57 Ibid.

58 "The Cold War and Red Scare in Washington: Historical Context," Center for the Study of the Pacific Northwest, http:/www.washington.edu/uwired/outreach/cspn/Website/Classroom\%20Materials/Curriculum\%20Packet s/Cold\%20War\%20\&\%20Red\%20Scare/II.html (accessed on August 12, 2015).
} 
the history was plainly told, textbook style with little analysis and even less guilt - much like the "interesting but irrelevant" concept presented by the 1964 Chronicle article.

This helps explain its appeal to those adherents of the official collective memory framework. In every academic treatment up to this point, the Legionnaire position had been under attack for its treatment of Wesley Everest and the way in which justice was ultimately not served by the Montesano trial. McClelland's text softened these criticisms substantially, which made it appealing to those who wanted to continue to support the Sentinel story. It gave those adherents an academic footing that they could grab and attach to other historical accounts. ${ }^{59}$

\section{The a academic framework continued}

A second major study followed McClelland's, potentially offering the interpretative intelligence Wollner described for the Tragedy and reasserting the independence of the alternative academic framework. Five years after McClelland's account, Copeland completed his book on Elmer Smith. He had spent nearly 23 years on it, having begun as an undergraduate student. Like McClelland, he worked on the book as he maneuvered his way through school and jobs. Also like McClelland, the book was not Copeland's first historical writing on Centralia. His article, "Wesley Everest, IWW Martyr," appeared in the Pacific Northwest Quarterly in the fall of 1986. Copeland challenged the myths that had arisen in most of the examinations of Everest, and disputed the Everest "castration" story. ${ }^{60}$ In his book, as in his article, Copeland relied on

\footnotetext{
${ }^{59}$ Moeller, Centralia Chronicle, Nov. 10, 2009; Robert Weyeneth, "History, He Wrote: Murder, Politics, and the Challenges of Public History in a Community with a Secret," The Public Historian 16, no 2 (1994), 53.

${ }^{60}$ As mentioned in the previous chapter, Copeland and McClelland disagreed on the castration story, a disagreement discussed at length in Kerry Irish's thesis.
} 
recording oral histories collected across the Northwest in addition to using the extant literature. His travel records are exhaustive, bouncing around the United States to track down letters, pamphlets and others materials primarily on Elmer Smith, the Centralia lawyer who had advised the Wobblies that they could legally defend their hall.

Because of this focus, the book's title, The Centralia Tragedy of 1919, is somewhat misleading, as the book focused on Smith's life as a whole. This narrative choice opened the door for the book's particular strength, its focus on the Smith's life after the Montesano trial. Copeland detailed the ways in which Smith sought freedom for the jailed Wobblies, living up to the promise to work for their release "as long as there is a breath in my body." ${ }^{61}$ Through this Copeland explored how Centralians were obsessed with the Tragedy well into the 1920s and the 1930s, and how the state of Washington allowed the Centralia prisoners to become a cause célèbre. The reader sees how Smith spritely barnstormed across the state, and how he often raised the ire of the local legal system. He was arrested on several occasions and the police shut down many of his public speeches. Copeland thus contributes to understanding of the Tragedy's impact on Centralia because he shows how it wore people down. It is easier to understand a "let's move on" mentality in the 40s and 50s based on just how much Smith and various Centralia Defense Committees besieged the public over the course of the Wobblies' imprisonment. Further, we see Smith take the banner of the Labor countermemory from writers like Chaplin and Walker Smith, hone it, and then pass it on to Ruuttila when he died. Copeland's analysis of the Wobblies in relationship with Smith is important. ${ }^{62}$

\footnotetext{
${ }^{61}$ Copeland, 85 .

${ }^{62}$ Melvyn Dubofsky. "Raising Less Corn and More Hell: Two Disciples of Mary Ellen Lease." Reviews in American History 23, no. 2 (1995): 266-271.
} 
Copeland humanized the Wobbly prisoners. He depicted Barnett as the ever-hopeful and ever-disappointed man in the wrong place. Ray Becker gets steadily more unhinged as the years pass, turning from one of the gang to Smith's most obstinate and disagreeable client.

What becomes obvious about the academic accounts of the Tragedy is that they consistently return the Tragedy to the human level. Unlike the Labor countermemory, which mythologizes the Wobblies, or the official collective memory, which cast the Legionnaires in bronze, the academic memory framework always reminded readers of the human characteristics that made the participants part of a far more complex historical event. Copeland placed Wobblies and the Legionnaires in a historical context. Perhaps unconsciously, Copeland attempted to bring the Labor countermemory framework back to earth, pointing out to adherents the danger of what they had done to these very human Wobblies who had experienced real suffering because of the Tragedy. However, by focusing on Smith, Copeland ended the story with Smith's death. So while Copeland fully detailed the communal impact of the case in the 1920s and 1930s, he wrote almost nothing on the events beyond 1932. Copeland stopped short of completing the story.

\section{Epilogue on an Era, the Gunns foreword}

One of the most poignant insights of this era of the collective memory of the Centralia Tragedy comes from Albert Gunns's foreword to Copeland's book. Gunns seems to have learned from the scolding he received from Ruuttila when he wrote that there had been "two Centralia cases: the case as fact and the case as symbol." "63 This is the first time that anyone identified the varied paths of collective memory of the Tragedy.

\footnotetext{
${ }^{63}$ Albert Gunns, Foreword to The Centralia Tragedy of 1919: Elmer Smith and the Wobblies, Tom Copeland (Seattle: University of Washington Press, 1993), x.
} 
Gunns's recognized the multiple paths that memory had taken with the Tragedy. Here was why the "authoritative texts" could not be authoritative: they had failed to recognize how split these narratives were in the hearts and minds of those who cared about the Tragedy. There can never be any authoritative text for Centralia. 
Chapter 3: The Ascent of Countermemory

In the popular history text, Lies Across America (1999), sociologist James Loewen described locations in the United States that he considered to be contested spaces of memory. He included Centralia's George Washington Park and discussed its prominent role in the histories of the Tragedy. Loewen argued Centralians were "not ready to address the events of eight decades earlier." Yet if we examine the experiences from 1970 to the publication of Loewen's text, it seems that Centralians were steadily addressing the 1919 Tragedy, as there were articles, public debates, and Chronicle features and even a school curriculum about the event. What Loewen actually meant was that all Centralians had not, as of yet, accepted the Labor countermemory, which he ascribed to as the true account. This chapter describes how from the early 1990 s to the present, the Labor countermemory became the primary narrative of Centralia, casting aside both the official and the academic memory frameworks.

In 1999, Loewen hoped that the mural, "The Death of Wesley Everest," would lead to "historical accuracy, memory recovery, and even reconciliation." It is hard to envision that this is really what Loewen was after, however, considering his own embrace of the Labor countermemory. This chapter demonstrates how the creation of the mural was a critical moment in the confluence of the frameworks, although in contrast to Loewen, it offered little opportunity for reconciliation.

\footnotetext{
${ }^{1}$ James Loewen. Lies Across America: What our Historic Sites Get Wrong (New York: Touchstone, 1999), 65-67. Even though historian Robert Weyeneth, whose work falls into the academic framework, influenced Loewen, he appeared less concerned with accuracy and more concerned with the ascendancy of the Labor countermemory framework
} 
Were historical accuracy, memory recovery and reconciliation really possible for the Centralia community, the occasion for these came a few years earlier, right around the time that public historian Robert Weyeneth attempted to place two sites (the Sentinel and Everest's grave) on the National Historic Register. More than previous historians, Weyeneth attempted to acknowledge the different frameworks and tie them together through the Register process. Simultaneously, Centralians also faced Tragedy history when a Centralia High School student, Cynder Viles, was afforded the chance to place a historic marker in town. In early 1992, Viles created a minor uproar with her proposed inscription for the marker. The incident highlighted the gulf between the various narratives while offering a moment for community dialogue that was never seized. The controversy over Viles's marker and inscription marked the end of the opportunities for conscious reconciliation of the Tragedy frameworks in Centralia, and opened the door for the Labor countermemory to assume local predominance. ${ }^{2}$

\section{A Tragedy textbook}

At the same time that Wobbly War was being declared an authoritative account, a group of local teachers crafted yet another. Centralia Tragedy Remembered: a textbook concerning a local history event for Centralia eighth graders was published by the Centralia School District in 1987, the same year as Wobbly War. ${ }^{3}$ Two middle school instructors, Joe Flink and Ron Breckinridge, were commissioned to pen the text, which was edited by district curriculum director Dr. Peter Hendrikson. According to Hendrikson's foreword, the two authors, "Vietnam era veterans... at Centralia Middle

\footnotetext{
${ }^{2}$ The author does not believe that historical reconciliation is necessary, even though at the onset of writing this thesis he believed it desirable.

${ }^{3}$ The entire text is available for perusal at the Timberland Library, Centralia Branch behind the main desk in a special collection of Centralia Tragedy documents.
} 
School," endeavored to take this complex historical incident and explain it to a younger audience. ${ }^{4}$ One man was a native to Centralia and "heard stories of the 1919 violence but had no lessons on the topic in schools," while the other "grew up in the town where the trial was held in 1920." ${ }^{, 5}$ The foreword opened with a comparison between the American experience of Vietnam, a "battle in our own streets," with "our grandfathers... who lived through a time of similar difficulties during World War I." ${ }^{\circ}$

When speaking about the book to the Seattle Times, Hendrickson commented that he didn't understand why more wasn't done in schools on the Tragedy, since "it was a pivotal event in the town's history, the thing that put us on the national map and in some history books.. ${ }^{, 7}$ He described the book's genesis: after a series of pilot lessons that Flink and Breckinridge had taught, some parents responded positively to the instruction and had asked when a book might be forthcoming. On the heels of that, Hendrikson prompted the two to create their short text. ${ }^{8}$

In his article in the Public Historian, Weyeneth argued that the textbook signified the community's willingness to have "frank discussion of local history." To Weyeneth, the book signaled a definitive shift in terms of the "climate of opinion being more open than ever before." ${ }^{10}$ Weyeneth, however, read too much into this middle school text. What Weyeneth reported as "more open" was either a general ignorance of the textbook

\footnotetext{
${ }^{4}$ Joe Flink and Ron Breckinridge. Centralia Tragedy Remembered: a textbook concerning a local history event for Centralia eighth graders (Centralia, WA: Centralia School District, 1987), foreword.

${ }^{5}$ Ibid.

${ }^{6}$ Ibid.

${ }^{7}$ Don Duncan. “Centralia's Secret.” Seattle Times (Seattle, WA), January 22, 1989.

${ }^{8}$ Ibid.

${ }^{9}$ Robert Weyeneth. "History, He Wrote: Murder, Politics, and the Challenges of Public History in a Community with a Secret." The Public Historian 16, vol. 2 (1994): 56. Weyeneth's perception of the work as "even-handed" is repeated in Duncan's 1989 Seattle Times article.

${ }^{10}$ Weyeneth, 56.
} 
(more likely) or a sense that its contents and perspective closely resembled McClelland's non-judgmental approach, which would be non-threatening to official memory framework adherents. If parents had picked up the pamphlet, the content that Flink and Breckinridge provided was not necessarily different to the treatments given before.

Flink and Breckinridge categorized the parties in the Tragedy into four distinct groups that "could be blamed for errors in judgment" when it came to 1919 events: The Legionnaires/I.W.W., the Judicial System, Law Enforcement, and the Public (or Public Sentiment). ${ }^{11}$ Like McClelland, Flink and Breckinridge opted for an approach that spread the blame, although it opened the door a bit wider than McClelland about who ultimately bore responsibility. They concluded the book somewhat innocuously, ending with an image of two middle school students, Chris Booth and Emily Mosier, staring at a floating question mark with the words "The Choice is Yours!" above their photo. A final segment implores individual responsibility:

The Centralia Tragedy might never have happened if each individual involved had exercised his responsibility as a lawful citizen...Anyone who allows anger, prejudice or extreme patriotism to cloud his judgment leaves himself open to be swept up in the mood of the mob. . . Human emotion unchecked by reason may lead to tragedy. ${ }^{12}$

In hindsight, this seems in line with mainstream American individualistic ideology of the Ronald Reagan era than anything critical of the official collective memory framework. Flink and Breckinridge appear to channel Reagan, whose 1980-1988 presidential administration was considered by some as the "embodiment of a tradition of rugged individualism.” Addressing the Republican party convention a few years earlier, Reagan, remarked that "the dream conceived by our Founding Fathers" was an "orderly society"

\footnotetext{
${ }^{11}$ Flink and Breckinridge, 18.

12 Ibid.
} 
that was also "consistent," with individual freedom. ${ }^{13}$ Even to an individual who adhered to the official collective memory framework read this, there is nothing significantly upsetting, contrary to Weyeneth's belief about the climate of opinion.

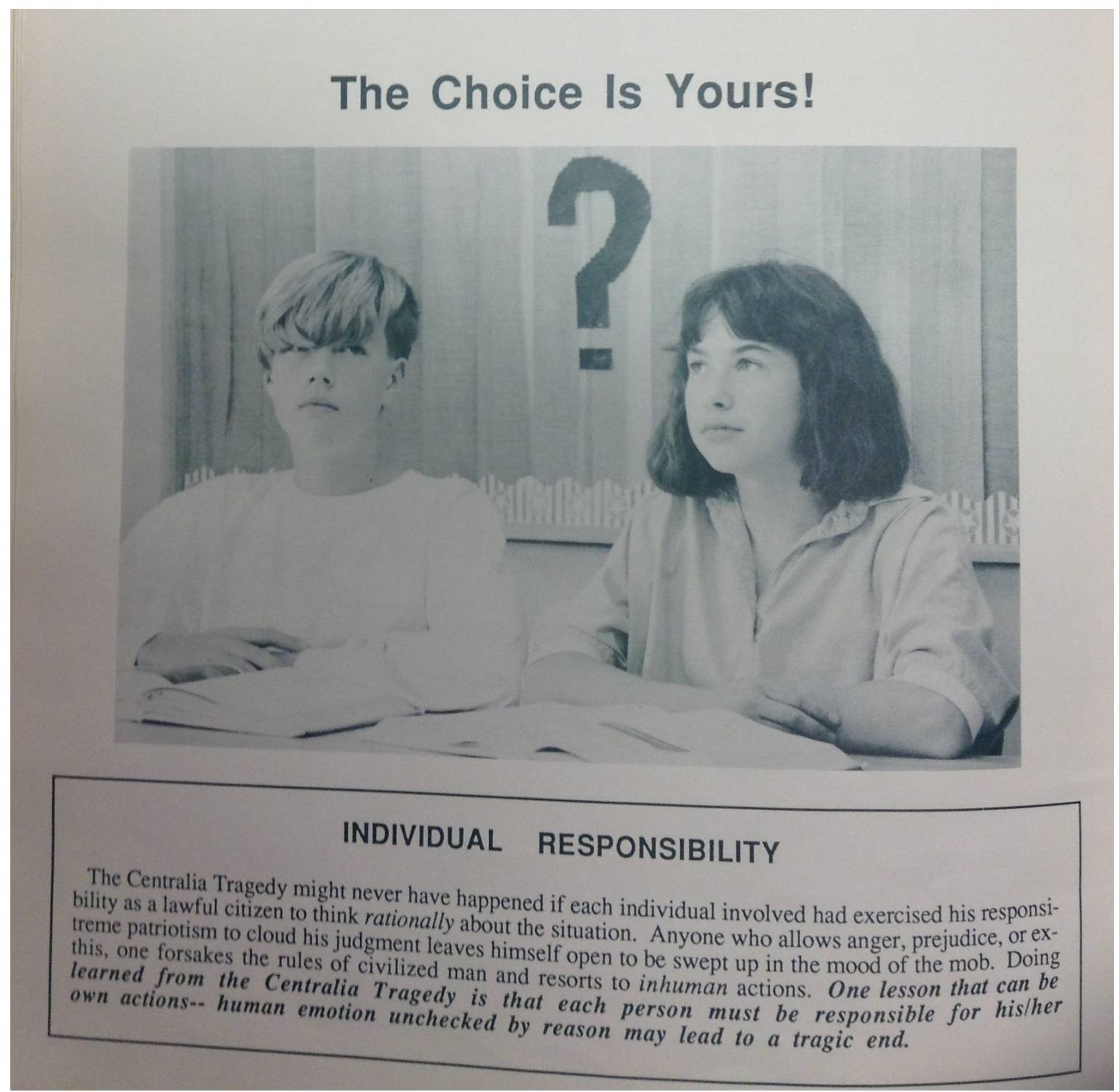

Fig. 11. Joe Flink and Ron Breckinridge. Centralia Tragedy Remembered. a textbook concerning a local history event for Centralia eighth graders, (Centralia, WA: Centralia School District, 1987).

\footnotetext{
${ }^{13}$ Cyrus Patell, Negative Liberties: Morrison, Pynchon, and the Problem of Liberal Ideology. (Durham, N.C., Duke University Press, 2001), 168-170.
} 
However, it is important to understand why Weyeneth, a historian intrigued by public memory, emphasized this work. What seems to have drawn Weyeneth's attention was that teachers wrote this book and schoolchildren read it, which he believed had not been done before with the Tragedy. ${ }^{14}$ According to Henry Rousso, several carriers can transmit historical memory: official (such as monuments), cultural (songs and stories) and scholarly (academic). ${ }^{15}$ What likely drew Weyeneth's attention was the movement of the Centralia story from monuments and journals to the middle school classroom.

Weyeneth gave weight to Flink's and Breckinridge's book because he saw it as a challenge to the official collective memory framework. Breckinridge remembered the strong opinions of his parents' generation, and he believed they needed some censure: "If history assigns blame for the violence, it must be spread among the Legionnaires, who planned to attack the IWW; the Wobblies, who overreacted with deadly force; local police, who refused to protect people they didn't like; and the public that became a mob."16 By a certain reading of this, Weyeneth might have categorized Flink and Breckinridge as more critical than they were, and their textbook, aimed at youth, as an unusual threat to the hegemony of the official collective memory framework. Had the content of the textbook been different, with the authors advocating greater acknowledgement of the need for justice for the Wobblies, Weyeneth might have been spot on. As it was, the only danger the book posed to the official collective memory framework was what it might inspire its student readers to do in the years ahead.

\footnotetext{
${ }^{14}$ This turns out to be a false presumption. Examination of files at the Timberland library in Centralia reveal that the Centralia Tragedy was something researched by students, as research papers by Centralia high school and college students are included in materials from the 1950s, 1960s and 1970s.

${ }^{15}$ Henry Rousso, The Vichy Syndrome (Cambridge, MA: Harvard University Press, 1991): 220-221.

${ }^{16}$ Ross Anderson, 'That Terrible Day': Centralia, 1919 -- WWI Veterans, Labor Unionists Clashed And Died -- This Little Town Has Only Lately Come To Terms With Its Infamous Armistice Day Tragedy" Seattle Times (Seattle, WA), November 11, 1999.
} 
In terms of collective memory, the role of Flink and Breckinridge's book is twofold. First, it plausibly gave Weyeneth (and later, Loewen) a justification for arguing that reconciliation was possible and desired, even in the face of evidence to the contrary. Second, its inclusion in the Centralia Middle School classroom in the 1980s, possibly spurred the Viles incident, where it became clear that the narratives were still present and at odds with each other.

\section{A historian attempts to foster reconciliation}

Weyeneth wanted to secure historic status for the grave of Wesley Everest, which was relatively obscured in a corner of Sticklin Greenwood Memorial cemetery in Centralia. Weyeneth detailed this process in his Public Historian article, which Loewen later drew upon. Weyeneth's interest started when he visited Centralia while working on a separate project and found no commemorative markers for the Tragedy. After talking to people, he determined that "the absence of commemoration was intentional, and I found myself disturbed by this effort to ignore, if not obliterate the past. ${ }^{117}$ Weyeneth's bent toward fostering reconciliation in Centralia emulated what Wyckoff called for in the Church Report while veering sharply from the role of previous academics in the discussion of the Centralia Tragedy. He was aware of his distinction, explaining that he grumbled "about academic historians and their abdication of responsibility for interpreting the past to general audiences." ${ }^{, 18} \mathrm{He}$ then set out to see if "a public historian" could "facilitate reconciliation with a problematical past." ${ }^{19}$ This started him on the process of earning a place for two sites - one from the official collective memory and a

\footnotetext{
${ }^{17}$ Weyeneth, 52

${ }^{18}$ Ibid.

${ }^{19}$ Ibid.
} 
second from the Labor countermemory - on the National Register. He ultimately hoped to place the controversial past "squarely in the arena of public discussion.",20

Weyeneth accomplished one of those goals: he got the register status. It didn't, however, generate much public dialogue in Centralia. There was some conversation in the City Council, which voted 4-2 to endorse Weyeneth's nomination. At one of those meetings Weyeneth did debate with a single member of the Tacoma Chapter of the I.W.W. Otherwise, there was little public disagreement with his proposal. ${ }^{21}$ And while the Chronicle included Weyeneth's efforts on its front page, only one letter to the editor was received at the Centralia Chronicle, and it argued against remembering "an incident of little importance and interest to present-day citizens of Lewis County."22 The author, L.N. Otis, explained that he/she would rather "rededicate the statue...to the current heros [sic] of the Gulf War."23 Weyeneth did get some regional and national press coverage of his effort — the San Francisco Examiner and National Public Radio produced pieces on his work — but these failed to earn much local chatter.

In the end, Weyeneth's project did not facilitate reconciliation or bring adherents of the two primary frameworks into dialogue, for two reasons. First, Centralians had no access in 1991 to the actual National Register listing, so the only way they could know about the joint status was through the reports in the newspaper or the informational plaques at both sites. Yet, even if plaques had been placed at both sites, Everest's grave is so remote from town that it would have hardly prompted critical dialogue. Likewise, a

\footnotetext{
${ }^{20}$ Ibid.

${ }^{21}$ Laura Towey, "Panel OKs site nominations," Centralia Chronicle (Centralia, WA), August 24, 1991. The article reviews how a 20 year old Wobbly, Barb Hansen argued that Weyeneth really didn't care about the effort but was simply looking for recognition among his academic peers. Weyeneth does reference Hansen (not by name) in his article

${ }^{22}$ L.N. Otis. "Rededicate Statue" Centralia Chronicle (Centralia, WA), August 14, 1991.

${ }^{23}$ Ibid.
} 
basic plaque at the Sentinel stating it was on the historical register would do little to bring the controversy to the forefront. Moreover, after the city council refused to pay for installing the plaques. So even that minute chance for sparking public dialogue on the Tragedy was lost. ${ }^{24}$ However, another opportunity for framework reconciliation was just on the horizon. Weyeneth, mostly inadvertently, helped to kill it.

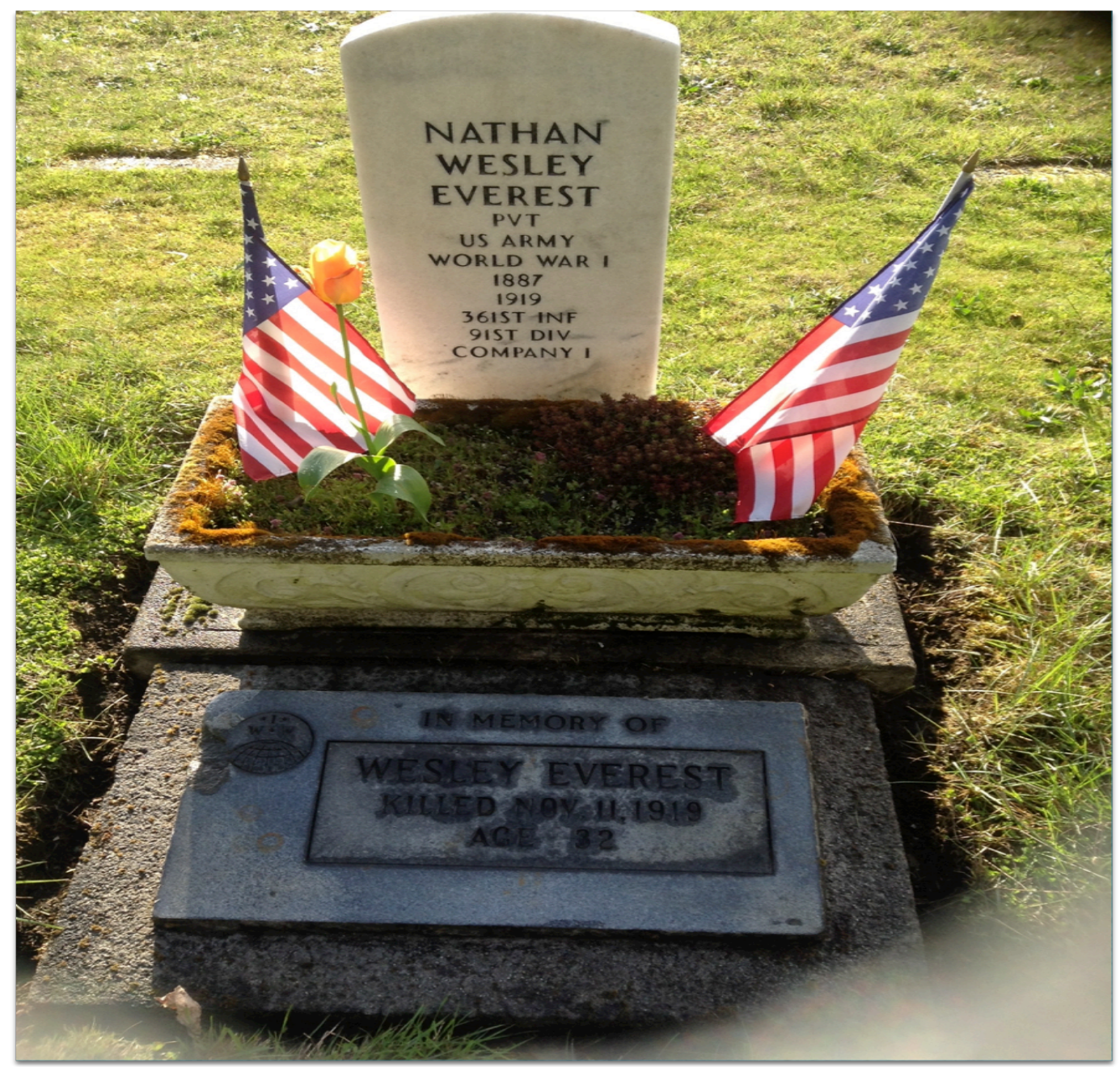

Fig. 12. Grave of Wesley Everest, photo taken by author, November 2013

\footnotetext{
${ }^{24}$ Robert Weyeneth (historian), in discussion with author, June 2013.
} 


\section{The Case of Cynder Viles}

In 1992 Cynder Viles was a 17-year old student at Centralia High School, and a year later she received with the Defense of Academic Freedom Award from the National Council for the Social Studies. This is an award annually given to an educator "to recognize and honor those who have distinguished themselves in defending the principles of academic freedom in specific controversies, in fostering academic freedom through advocacy, and in defending or advocating the freedom to teach and learn."25 Typically, the person honored is a K-12 teacher, but in 1992 the Council decided, for the only time in its history, to present it to Viles, a student. Lawrence Lowther, a professor at Central Washington University and chairman of the statewide Social Studies Council, nominated Viles for "great courage...in sticking by her historical conclusions and insisting they receive a respectable hearing in the face of tremendous public pressure to change them or obscure them., 26

Viles had spent the previous months fighting members of the Centralia community for the right to install a historical marker she designed about the Tragedy, a situation that might seem odd considering the lack of fanfare associated with Flink, Breckinridge and Weyeneth's efforts. In 1991, Viles participated in the Washington History Day contest, an annual statewide event where middle and high school students compete to demonstrate their historical acumen through written reports or trifold posters. That year, the Washington History Day included a special contest sponsored by Quiring Monuments, Inc., of Seattle, which donated 275-pound commemorative granite tablet to

\footnotetext{
25 "Defense of Academic Freedom Award," National Council for the Social Studies website, http://www.socialstudies.org/awards/academicfreedom (accessed March 3, 2013).

${ }^{26}$ Lawrence Lowther, Letter to Pascal Gilmore, June 30, 1992. FP-18, Faculty Papers, Lawrence L. Lowther. Archives and Special Collections, Brooks Library, Central Washington University.
} 
place in the winner's town. ${ }^{27}$ Viles entered this contest and won with her entry about the Centralia Tragedy. After Viles won the contest, she sought and gained the approval of the Centralia Historical Commission to place the commemorative granite tablet in George Washington Park. The Commission sent the proposal to the City Council on January 21, 1992, and the Council voted 5-1 to install it in George Washington Park. ${ }^{28}$

Usually small cities revel when a local student wins a statewide award. Initially, the Historical Commission and the City Council followed this general pattern. In the weeks that followed, however, both City Council members and Centralians writing to the Chronicle mobilized to stop the installation. Why did Viles's efforts earn the enmity of a significant segment of Centralia's population? She was a Centralia Middle School student who most likely was taught the previously uncontroversial curriculum by Flink and Breckinridge, and there was the well-detailed effort by Weyeneth to get national recognition for Wesley Everest. What spurred debate was Viles's inscription for the marker. Viles designed it to provoke, including a claw hammer to represent the workers, and a noose to represent the hanging and lynching. The marker stated:

During WWI the revolution of the labor unions took place in America and all around the world. Incidents like the Centralia Massacre touched the way of life all across the country, helping to bring about changes that would transform our economy forever into the world power we know it as today. Because people in the unions believed in and were willing to die for, the right of equality between the working class and their employers, the dream that they shared of an 8 hour day, Social Security, Worker's Compensation, Occupational Health and Safety, and Job Security, has been accomplished, and in fact is now a reality in the lives of their children. ${ }^{29}$

\footnotetext{
${ }^{27}$ Ibid. In this particular competition, there were many prizes awarded - from best use of archives to best presentation on women's history. Viles would have had to plan for this award, since she had to present a "mock up" of her historical marker in addition to her research project.

28 "Monument to 1919 incident wins backing," Centralia Chronicle (Centralia, WA), Jan. 22, 1992. Take note that her vote was even more favorable than Weyeneth, who in his process mustered more opposition.

${ }^{29}$ Cynder Viles, Coming of Change, The Centralia Massacre, 1992.
} 
This inscription and the plan to place the marker inside George Washington Park, the hallowed ground of the official collective memory framework, generated the outcry.

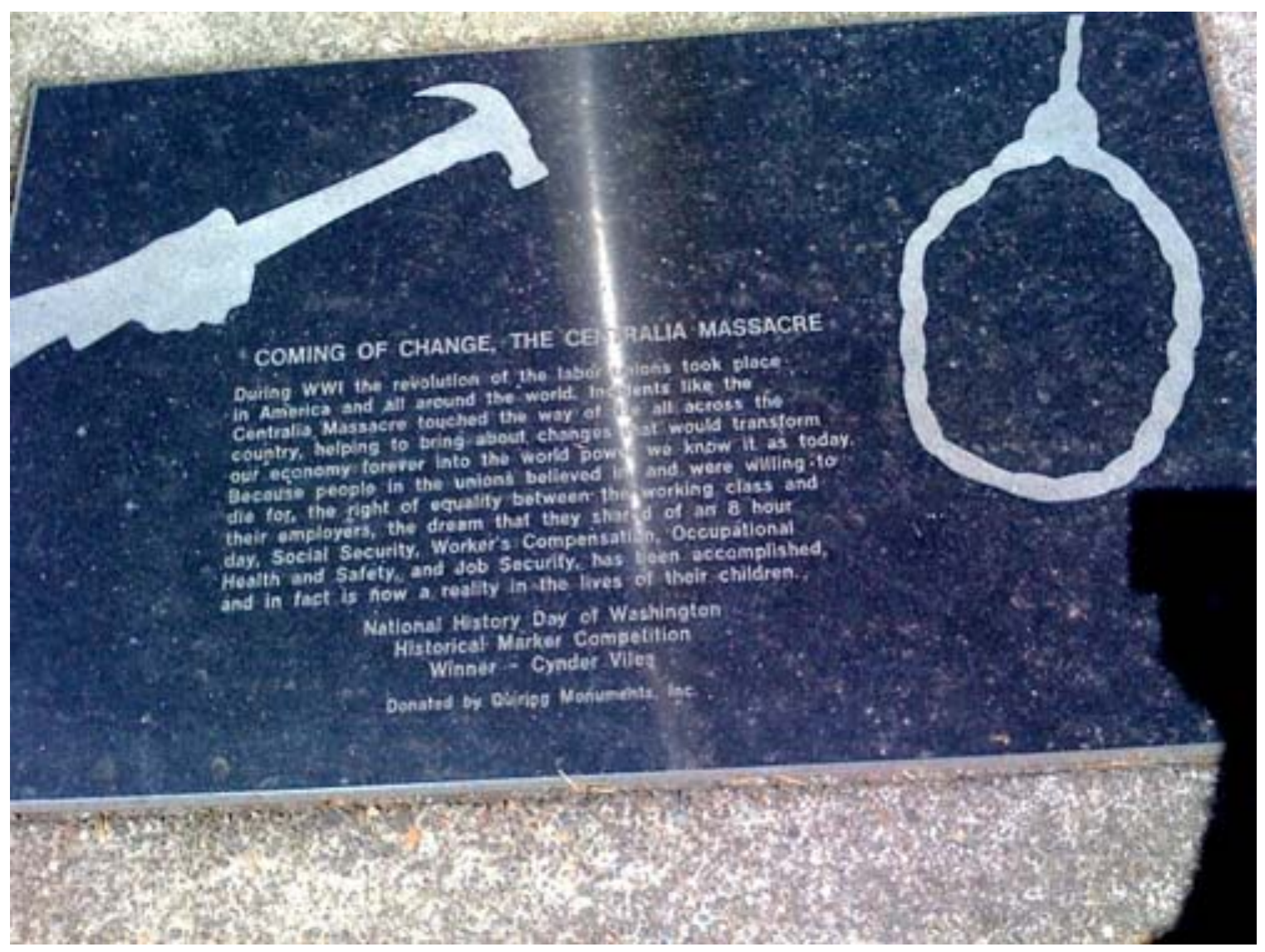

Fig. 13. Cynder Viles's Marker in George Washington Park, photo taken by author, November 2013.

To be fair, the design and description did give reason for pause. Weyeneth himself criticized the Washington State contest for allowing Viles's entry, as in his estimation the inscription was "poorly-written prose" and "ahistorical." 30 Instead of working with Viles and her teachers, however, Weyeneth went straight to the general

\footnotetext{
${ }^{30}$ Weyeneth, 70. He alluded to how it should have been more rigidly edited by some teacher along the way. This contention certainly has merit. As Weyeneth explained, Viles abbreviated regional and national history and, from a strictly academic sense, jumbled the sequencing of Labor events.
} 
public through a Chronicle article published a few days after the Council's vote. The Chronicle in this instance reverted to its role as an arm of the official framework, and appropriated Weyeneth as it had done previously with McClelland, describing him as a "Massacre History Authority." Weyeneth, the paper reported, recommended that the marker be located elsewhere, like the Mellen Street Bridge or Centralia High School. ${ }^{31}$

If Weyeneth were in search of reconciliation, he might have worked with Viles to place her marker in the park as a complement to his. Considering his initial concern that Centralia lacked memorials, his response is perplexing. The press Viles was getting provided an opportunity for public dialogue between the frameworks that he claimed to want. Instead, he publicly criticized her, encouraging further polarizing attacks on Viles.

One week after the City Council approved Viles's marker, the Chronicle published an article quoting the dissenting member of the Centralia Historical Commission, Ingrid Selby. She stated that she voted against Viles because "If we are going to do something, it should be historically correct.",32 A "Reader Commentary" on January 31 insisted: "If we are going to build a monument to our local history, I think we would at least want to show visitors that we know what our history is." ${ }^{\text {,3 }}$ The author, James Smith, also questioned the inclusion of the claw hammer, noting that the lumberjacks and millworkers would have used "the double-bitted ax, the 'misery whip,'

\footnotetext{
${ }^{31}$ Laura Towey. "Massacre History Authority questions plaque content," Centralia Chronicle, (Centralia, WA), January 29, 1992. Interestingly, a Feb. 7 Chronicle article "Plaque Discord Startles Creator" indicates that Weyeneth spoke to the Chronicle before the first vote, but his comments were held until after. Weyeneth also added that another marker was planned for the park, one he had been working to get. He did not note that his plaque was just for the Sentinel.

32 John Pierce. "What's best site for plaque: Historic Panel members explains negative vote." Centralia Chronicle (Centralia, WA), February 4, 1992.

33 James A. Smith. "Massacre monument needs more thought." Centralia Chronicle, (Centralia, WA), February 12, 1992.
} 
the pike poke and the peavey. Would we want visitors to think we don't know that?"34 Selby's and Smith's comments don't necessarily correspond to a specific memory framework, yet it was a twist to see non-academic adherents of any framework worry about historical accuracy. Further, at no point in the controversy did critics argue in favor of revising the Sentinel inscription to be historically accurate.

The noose on Viles's marker also got its share of press. Save for Peter Lahmann, the Chair of the Historical Commission, who wanted to keep the noose because the mob should have hanged more of the Wobblies, the majority of people shown the design by City Councilor Bill Rickard "found it offensive" and "very graphic."35

Adding to the clamor, an unsigned Chronicle editorial on February 14, 1992 bluntly stated: "Plaque not suitable for Washington Park." The editorial noted it was "not picking on Viles," who was "to be commended for her interest in the Centralia Massacre." However, it went on to argue: "to have a separate monument to a man who was [a] murderer...is viewed by many as a desecration. No need for that, no need to open old wounds...Keep it out of Washington Park."36

Viles was resolute in resisting any changes to her inscription and visuals, and insisted that everything about the marker was appropriate. She later explained that, "in my community, there are still those...that would like very much to cover any past guilt." 37 Her father, Gregory Viles, defended her choice of the noose, noting that the design was intended to encourage thought, and that it symbolized that "there has been a

\footnotetext{
34 Ibid.

35"Monument to 1919 incident wins backing." Centralia Chronicle.

36 "Plaque not suitable for Washington Park." Centralia Chronicle, (Centralia, WA), February 14, 1992.

${ }^{37}$ Lowther, Letter to Gilmore.
} 
risk and there has been a price paid." ${ }^{38}$ As for the suggestions to place the marker elsewhere, she was equally resistant: "I felt that to place the monument where it would not be seen would be pointless...It is my opinion that since the marker would be given to the people it should be where all may see, enjoy, and most of all learn from it." ${ }^{\prime 39}$

Ultimately, the City Council honored its initial decision and in late 1992 Viles's marker was installed in George Washington Park a few steps behind the Sentinel. It is the only monument in the park that is not raised off the ground, and visitors can easily pass by it without notice on the path to the Timberland Library. Before the marker even had a chance to spark any form of community dialogue, it was immediately overshadowed by other changes made to the park. A separate committee developed a series of installations to commemorate Lewis County military service after World War I, to be known as the "Freedom Walk." When Weyeneth visited in the late 1990s, his first impression was that the Sentinel "was given even more prominence than before." 40 Further, he felt that that installation of the "Freedom Walk" was an effort to "depoliticize the symbolism of a controversial public space." By tying additional memorials to the Sentinel, the community "renew[ed] the legitimacy of The Sentinel." ${ }^{41}$ He concluded:

As a consequence, it is now difficult to argue, as the high school student did, that "the other side" ought to be marked in the interests of "historical balance," since the message proclaimed from the square can be characterized as apolitical rather than partisan. In effect the town square has been transformed from contested terrain into patriotic ground... in this light, the new Freedom Walk suggests the journey toward historical reconciliation remains unfinished." ${ }^{42}$

\footnotetext{
38“Monument to 1919 incident wins backing." Centralia Chronicle.

${ }^{39}$ Cynder Viles, "Statement to the NCSS," FP-18, Faculty Papers, Lawrence L. Lowther. Archives and Special Collections, Brooks Library, Central Washington University.

${ }^{40}$ Weyeneth, 72.

41 Ibid.

${ }^{42}$ Ibid., 73. Jonathan Nelson. "War memorial plaque planned for city park." Centralia Chronicle, (Centralia, WA), January 24, 1992. In the Centralians' defense, the origins of Freedom Walk predate the Viles marker and may not have been an effort to depoliticize as Weyeneth and later, Loewen, suggested.
} 
The fate of Viles's marker represented a lost opportunity for the frameworks to be discussed in a new way. Her insistence on putting the marker in George Washington Park, a space of contested memory, intended to open up dialogue. Her poorly-worded inscription also provided an opportunity for the entire community, maybe guided by an academic, to draft a marker that accurately described the Tragedy and allowed for a convergence of frameworks. Residents could have contemplated the social and political forces that seized the town in 1919 and thereafter, and engaged in a historical dialogue, if not reconciliation. Instead of seeing this moment for what it could be, what he wanted, Weyeneth instead catalyzed another conflict of frameworks. It was as if Weyeneth retreated to the position others within the academic framework had taken: that of the detached outsider. The academic framework, it should be noted, ended with Weyeneth. From 1994 to the present no reviewed academic work has been published on the Tragedy, nor has either the other frameworks sought out academic support.

Viles was too young really to be an effective representative of the Labor countermemory, but adherents of the official memory framework nevertheless painted her into that position. Instead of working alongside an adolescent to draft an inscription useful for the community, they provoked her to insist on her wording. Adherents of all three frameworks could have collaborated to represent all positions thoughtfully in a marker, plaque, or public forum. While Viles's critics may have thought preventing this convergence was a victory, especially if the Freedom Walk was meant to depoliticize the

Yet, Weyeneth was correct in noting that the Freedom Walk helped to eliminate the possibility for reconciliation between the collective memory frameworks of the Tragedy. 
space as Weyeneth thought, it proved pyrrhic. Ultimately, the resolution of the Viles saga led to the ascendancy of the Labor countermemory in remembering the Tragedy.

\section{Resurrecting Wesley Everest}

The mid 1990s did not necessarily see an abatement of interest in the Tragedy story. The Lewis County Museum, in a reversal from a decade before, hosted in November of 1994 an exhibit on the 75th anniversary of the event. The exhibit's opening received mention in the Chronicle. ${ }^{43}$ McClelland served as the featured speaker, and many attendees took home copies of his book. In that same year, a Chehalis filmmaker, Hugh Crawford, directed a movie, The Peaceful Parade that was screened at the Museum. Called a documentary by the Chronicle, The Peaceful Parade is actually an "imaginative reconstruction of the Armistice Day Parade in Centralia (WA) on November 11, 1919." "44 The film is 22 minutes of amateur actors poorly portraying Warren Grimm and other Legionnaires in the moments before the shooting started. ${ }^{45}$ The film is an argument that the parade was meant to be peaceful until Grimm made a mistake by not saying "eyes right" during the parade. This led the Legionnaires to think they had the go ahead for the raid, which in turn led the Wobblies' to kill Grimm, which Grimm deserved for making his initial mistake. ${ }^{46}$

Neither the exhibit nor the film, both of which seemed to advocate for the same conclusions that McClelland laid out in Wobbly War, were substantive enough for John

\footnotetext{
${ }^{43}$ Margaret Shields (Lewis County Museum staff), in discussion with author, June 2, 2015; Laura Pierce. "'Riot' exhibit gets high marks," Centralia Chronicle (Centralia, WA), November 2, 1994.

${ }^{44}$ Hugh Crawford. The Peaceful Parade. Liner Notes, 1994.

${ }^{45}$ This film is available in the archives of the Timberland library, although it is not listed on their materials. The author stumbled across mention of the film while reviewing a November 1997 letter to the editor entitled "Movie Nonpartisan Account" in the Chronicle in which Crawford's stepdaughter, Linda Sparhawk-Linder, referred to it being at the library.

${ }^{46}$ The Peaceful Parade, 1994.
} 
Regan. Regan owned the Centralia Square Antiques Mall building that overlooks George Washington Park and the Sentinel. In the late 1990s, Regan finally "felt it was time that labor's side of the 'Centralia Massacre' was represented, and wanted a mural that would tell the story." ${ }^{47}$ Regan contacted a labor muralist, Mike Alewitz, who had produced other labor murals and was familiar with the Everest story. ${ }^{48}$

Regan and Alewitz then assembled the Centralia Union Project Committee to gain financial and community support for the mural. The committee consisted of a wide array of Centralians - from union leaders and educators to business leaders. Alewitz spoke to several surrounding communities about the project, catching the attention of documentarian Anne Fischel. Fischel, a professor of media studies at Evergreen State College in Olympia, Washington, went on to produce a film about the mural and the ongoing social, political, and economic struggles in Lewis County. ${ }^{49}$

The mural creators argued that it was intended to encourage community dialogue, although that dialogue was to be dominated by the Labor countermemory. Fischel rationalized this bias by explaining that ultimately the people of Centralia, particularly those who showed up at the Mural Committee meetings, were concerned about having a voice in determining the future of Centralia. ${ }^{50}$ This desire for a voice empowered the Labor countermemory more than at any other previous point. With various economic challenges faced by the people of Lewis County through the 1990s, as mills, mines and

\footnotetext{
${ }^{47}$ Mary Slough, “Centralia's Union Mural,” Columbia The Magazine of Northwest History 13, no. 3 (1999): 24.

48 Ibid.

${ }^{49}$ Anne Fischel (documentarian), discussion with author, September 26, 2014.

${ }^{50}$ Ibid.
} 
companies closed, all of which are highlighted in Fischel's film, the Labor side of the Tragedy gained steady appeal.

This is evident in the comments of Kathleen Campbell, a business leader and then-president of a group called "Destination Centralia." Sixteen other murals in downtown Centralia depict the early history of the town. Campbell was confident that adding a seventeenth would draw visitors. ${ }^{51}$ She emphasized that the Tragedy was a historic event similar to those that occurred in other communities, like Everett, and that the town had to get past its "paranoia." 52 The idea of monetizing the history the Tragedy represented yet another shift in memory. While the Chronicle had profited from the events through readerships over the years, the businesses of Centralia never seemed terribly interested in using this past in pursuit of revenues. Yet because of economic hard times, local businesspeople, previous adherents to the official collective memory framework, were collaborating toward in a Labor countermemory public commemoration.

The entire community, however, was not on board with the project's emphasis on the Labor countermemory interpretation of 1919 . This became clear when members of the Mural Committee, like Bill Henry, a great-grandson of juror Will Inmon (one of the jurors that submitted an affidavit trying to exonerate the Wobblies), told the Seattle Times that the mural "will finally tell the history that has been suppressed," repeating the adage

\footnotetext{
51،"Sharon Michael, "Recalling a Sad Day,” Agitprop News Special Centralia Mural Issue, Oct. 30 1997, https:/groups.google.com/forum/\#!topic/misc.activism.progressive/5P4AIA_yvKQ (accessed on September 26, 2014).

52 Ibid.
} 
about a secret. ${ }^{53}$ Soon after dissent became vocal about the mural. The Grant Hodge Post of the American Legion expressed its opposition, which was then endorsed by the state conference and the national convention of the American Legion. The condemnation reached the point of an official Legion Resolution, which reiterated the Legion position that "the IWW did plan to ambush members of the Grant Hodge Post \#17" and "did open fire on and kill (4) Legionnaires." The resolution further attacked the committee, which it characterized as "a group of labor officials, college professors, and current members of the IWW" that was going to honor the "assassins.",54

The Chronicle printed an exchange between Alewitz and Don Bradshaw of the Post 101 of the American Legion, based in nearby Winlock, Washington. Bradshaw opined that Everest had been in the "background" of the story and "should stay in the background." The Everest mural would "divide the community" or worse, "get someone hurt again." He worried that "Vets will go out of their way to deface it." Alewitz noted that if Bradshaw were issuing a threat to hurt people or encouraging someone to deface the mural, he was breaking the law. ${ }^{56}$ Alewitz also revisited the town's history, asking Bradshaw if the "American Legion [was] planning violence against the workers of this town who are promoting the mural project, the way they planned violence against the IWW in 1919." ${ }^{, 57}$ Alewitz challenged Bradshaw to a debate, noting that the

\footnotetext{
53 "Centralia Mural to Mark Labor Fight." Seattle Times, (Seattle, WA), March 10, 1997. As discussed in chapter 2, this concept of the secret still seems confused by observers. The actual secret of who killed Wesley Everest mixed with the mistaken idea that the people of Centralia are actively hiding the story of the Tragedy.

${ }^{54}$ Resolution No. 140 Seventy-Ninth National Convention of the American Legion, September 2-4, 1997. 55 Sharon Michael, "Feelings still tender, though event was long ago." Centralia Chronicle (Centralia, WA), October 25, 1997.

56 Mike Alewitz, "Winlock mayor challenged to public debate to defend amazing comments on Centralia mural. Centralia Chronicle (Centralia, WA), October 30, 1997.

${ }^{57}$ Ibid.
} 
mural was a "gift" to the town from the working people of Centralia, and that he expected that the authorities would protect and defend that gift as a "valuable contribution to the culture that it is." 58

While the debate never materialized, the Centralia Union Committee members were concerned about a possible counter demonstration on the day of the mural's unveiling. Committee co-chair Henry approached the American Legion leadership, and found that the Grant Hodge Post had no intention of disrupting the unveiling. There are telling parallels between 1919 and 1997. In 1919, Elmer Smith made the same walk that Bill Henry made to the American Legion, only to be rebuffed on a commitment to leave the Wobblies alone. In 1997, Henry convinced the Legion that sustained protest served no productive end. While I do not know what Henry said at that meeting, I would imagine he simply argued that the mural would lend the balance that most Centralians recognized was necessary. This would explain the Legion's unwillingness to protest the mural, even after the local, state, and national branches all condemned it. Likely, community ties were more important than disagreement over the collective memory of events. Notably, while the Legion maintained its official collective memory framework of events, it did not, in the following years, assert its position as the steward of official memory.

\section{The Mural Unveiled}

On Saturday, December 13, 1997, the mural was unveiled before a sizable crowd in Centralia's main square. Several papers, from the Chronicle to the Washington Free

\footnotetext{
${ }^{58}$ Ibid. I wanted to make a note at this point of the similarity between Alewitz' call to the authorities and the handbill used by the Wobblies in 1919 to call the police to operate as the legal safeguard of law and order.
} 
Press, covered the event. On hand were several people with connections to the Tragedy itself. Esther Barnett Goffin, the daughter of Eugene Barnett, was a principal speaker. She spoke about her father's innocence and the need for her father to finally receive some form of pardon from the Washington state government. As she explained to the Columbian, "I hate that the history books depict my dad as a murderer. He tried his whole life to clear his name," adding, "I hope the truth will be told for a change." Relatives of Wesley Everest were also on hand. A cousin, Crystel Rilee, referred to the event as "a tragedy... something that shouldn't have happened." $" 60$

The mural's success made it clear that the Labor countermemory framework was taking hold. Alewitz's design included several 1910s-era attributes, the most prominent being Everest, arms raised like a resurrected Jesus, as the centerpiece. Everest is clothed half in a World War I uniform and half in logger's clothes, to show his connection to each. He is flanked by Tom Lassiter, the blind newspaper salesman who had been thrown out of town in 1918, while "Sabo Tabbys," the black cat sabotage symbol of the Wobblies, rain from the clouds in the background. There are more pointed inclusions $-\mathrm{a}$ man "spewing fecal matter" representing "established power" in Centralia -- business and the news who created the hysteria that led to the Tragedy. There is also a "capitalist pig" that is sleeping, surrounded by money and being hugged by a "block head" and a "porkchopper." The pig represented logging company owners, the block head the

\footnotetext{
59 "Centralia Mural Acknowledges Massacre After Years of Denial," The Columbian, (Vancouver, WA), Dec 16, 1997. I am uncertain which history book she is referring to, having not seen any evidence of Barnett being unequivocally referred to that way. Even unfavorable accounts have been sheepish on his score.

${ }^{60}$ Scott Sunde, "Thanks to Mural, No Brushing Aside Centralia Conflict." Seattle Post-Intelligencer (Seattle, WA), December 13, 1997.
} 
workers that naively followed the bosses, and the porkchopper the bureaucratic union boss who cared little for the workers. ${ }^{61}$

However, beyond these historical images, the mural also incorporated designs meant to represent the contemporary economic and ethnic minorities of Centralia. On one side of the mural are the words "I Will Win" - an old Wobbly rallying cry - on a banner. On the other side they are written in Spanish - "Susa Puede" representing the immigrant workers then living and working just a few blocks away, in an area referred to as "Little Tijuana.", 62 There was also heavy coal-mining equipment, representing the nearby TransAlta mine. Alewitz also incorporated a few tributes - most notably "Mount Helen Lee," a nod to the Evergreen State College professor who helped produce the mural.

When Alewitz took the lectern at the unveiling, he detailed this appropriation of the Labor framework by noting the dual nature of the mural. He remarked that it aimed beyond Centralia. He noted that there was a greater need for unions today and he explained that Wobbly heritage was not only the property of labor unions but of working people as a whole. It was a "sacred trust for the working people."63 He dedicated the mural to imprisoned activists Mumia Abu-Jamal and Roisin McAliskey - neither of whom had any connection to Centralia. Other speakers also addressed contemporary matters, commenting on the workers in "Little Tijuana," who they claimed were unable

\footnotetext{
61 "Evidence of Centralia Massacre Visible Today." Centralia Chronicle (Centralia, WA), April 22, 2014.

${ }^{62}$ John Ruhland. "Wobbly War Commemorated - Labor Mural reminds the city of Centralia about its suppressed labor history." Washington Free Press. March/April 1998.

${ }^{63}$ Lewis County Hope and Struggle, directed by Anne Fischel,(2004; Washington: Right to Know Productions, 2007), DVD.
} 
to attend the ceremonies under a fear of retribution from employers. ${ }^{64}$ When the day closed, Wesley Everest stood resurrected.

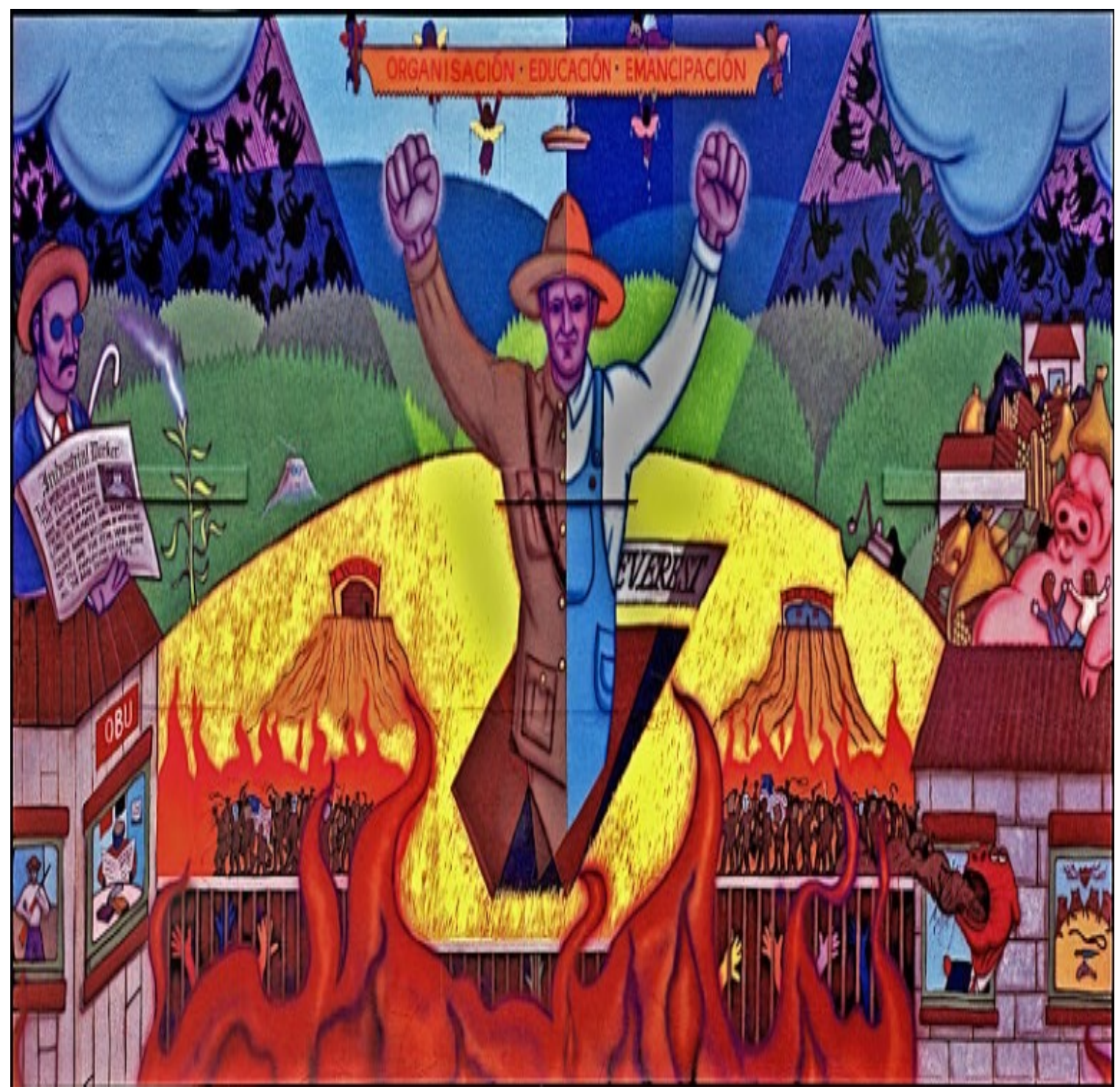

Fig. 14. Mike Alewitz, "The Resurrection of Wesley Everest,” Mural, 1997.

\footnotetext{
${ }^{64}$ Ruhland, "Wobbly War Commemorated."
} 


\section{And the Chronicle}

In Brian Mittge's recollections, the Chronicle went through particular cycles in its Tragedy reporting, particularly in the late 1990s and early 2000s. Usually this included an new editor approaching him, ecstatic at discovering the "hidden" history of the Tragedy and declaring the Chronicle needed to write about it. Mittge's most notable work was a five-part series that editor Michael Wagar assigned him in 2001 after Wagar learned about the Tragedy from a community event. ${ }^{65}$ Wagar's experience reveals something about the recurring claim that there is a "secret" history, in the sense that Centralia is suppressing the story. Beginning in the mid-1990s, the claims appears when someone like Wagar stumbles upon the Centralia story through an event usually connected to the Labor countermemory framework. Slowly, in the past 20 years, more and more Chronicle features have represented the countermemory than either the academic or the official collective memory framework. Mittge's series in 2001 demonstrated this trend.

The first two parts of Mittge's 2001 series were typical fare retelling the events of the Tragedy. The influence of Copeland and McClelland is evident, and Mittge's work is representative of their journalistic-historical approach. In the following two parts Mittge added more voices with a bent toward the Labor countermemory framework, including conversations with modern-day Wobblies, a relative (grand-nephew) of Everest, and an oral history/taped conversation with three men recalling the day. In Mittge's view, this part of the series was the first time that the Chronicle incorporated these community voices, allowing them to "become involved with the story." 66 This might not be precisely

\footnotetext{
${ }^{65}$ Mittge, "Framing Tragedy," 25-26.

${ }^{66}$ Ibid, 26.
} 
true, although Mittge did give more weight to those voices. His articles leaned heavily toward the Labor perspective.

\section{Labor ascendance}

The official collective memory framework, however, did not completely disappear. Mittge also connected with Jack Cunningham, the son of attorney C.D. Cunningham. Jack Cunningham maintained his father's viewpoint on the Wobblies, and when asked about the inclusion of the Wobbly perspective in Mittge's articles, remarked that "if a murderer's entitled to some exaltation, then so be it." ${ }^{67}$ He added: "the only change I notice [about the story] is the unions keep bringing it up. I don't know who it is, sympathizers or what."68 Despite Cunningham's "murderer" barb and disdain for the Labor memory framework, he seems resigned to the ascendancy of the Labor perspective. No longer was the Tragedy a contained narrative. It had grown and spread beyond the confines of the city.

There have been multiple attempts to craft a film about the Tragedy, from Eleanor Walden to Sandy Polishuk to Ursula Richards-Coppola's. ${ }^{69}$ Most films have either died in production or were poorly made, like The Peaceful Parade. The allure of crafting a film about the Tragedy is clear, as film offers to carry s framework of memory at a far greater rate of impact than any other means. ${ }^{70}$

\footnotetext{
${ }^{67}$ Ibid.

68 Ibid.

${ }^{69}$ Sandy Polishuk (oral historian and Ruuttila biographer), in discussion with author, June 10, 2014. Polishuk shared that she had sent a treatment to director John Sayles with no response. During this conversation she and I shared several concepts for crafting this story into cinema, based on dialogue we both had with interested parties; "Film producer aims to set record straight" http://hangmansbridge.webs.com/filmmaker.htm (accessed Sept. 27, 2014). The author also received an email from Al Gunns encouraging him to speak to a filmmaker in Vancouver, B.C. who had contacted him in 2014 about a film treatment.

${ }^{70}$ Rousso, 220-221.
} 
Anne Fischel, an Olympia resident, produced the one successful film about the Tragedy. After Fischel met Alewitz, the Mural Committee asked if she would be willing to make a documentary. ${ }^{71}$ The result, Lewis County: Hope and Struggle, described the events of the Tragedy, and then moved into a discussion of economic and social issues facing local residents. She concluded by focusing on the production and unveiling of the mural.

Fischel defined her film as a Labor narrative. ${ }^{72}$ Her stance on what happened in Centralia in 1919 was fully aligned with the Labor countermemory framework. Her narration explained that the Legionnaires attacked the hall. She did not qualify this with any information about the ongoing debates about this point. She referred to the castration of Everest as fact. ${ }^{73}$ When speaking about these choices, Fischel indicated that while she had met and read Copeland, she felt that, from her understanding of the history of lynching, that castration was common practice and thus it was believable to her that this had occurred to Everest. ${ }^{74}$

In the film's final ten minutes, Fischel turned the camera on the Centralia Mural Project Committee, and viewers hear members discuss their reasons for participation. One woman talked about how her participation began with historical curiosity, but morphed into a need for the mural to give workers in Lewis County "hope." Another member remarked that it was important for them to do the work because no one else in the community was going to recognize workers, especially the businesses that only

\footnotetext{
${ }^{71}$ Anne Fischel (documentarian), in discussion with author, September 26, 2014.

72 Ibid.

${ }^{73}$ Lewis County Hope and Struggle, 2004.

${ }^{74}$ Anne Fischel (documentarian), in discussion with author, September 26, 2014.
} 
created minimum wage jobs. ${ }^{75}$ Still others described how a mural of Everest served as a sign of hope and a statement to the corporations that controlled Centralia's turn of the century economy.

All told, the film is a time capsule of the life of the Labor countermemory framework, and its generally high quality have worked to ensure further transmission and ascendancy of that framework. Fischel demonstrated how the framework cleaved itself from the academic tradition through her choices, for example, to ignore the historical debate about the events of November 11,1919, or the Everest castration. Further, by tying her narrative of the Tragedy to the economic woes of the average Centralian, and their grasping onto the mural project as a means of communicating their contemporary plight, Fischel showed how this framework has achieved primacy in today's conversation. As an increasing number of Centralians resembled the workers of yesteryear rather than the Legionnaires or Labor-unfriendly business leaders, the community's propensity for Labor's message was far greater.

\section{The 2009 Lyceum}

Susanne Weil started work as a professor of English at Centralia College in the mid-2000s. Like others before her, she encountered the Tragedy when she was preparing for her move to Lewis County, and her initial Internet searches of Centralia led to stories about the Tragedy. Yet, when discussing the event with her Centralia College students, very few of them knew the details. Weil was shocked that was the case, considering that it was one of the first things she discovered about the location after typing it into a search

\footnotetext{
${ }^{75}$ Lewis County: Hope and Struggle, 2004.
} 
engine. ${ }^{76}$ Weil experienced how things had changed — from the Centralia Tragedy textbooks and middle school lessons being out of use to a general quieting of Tragedy conversation. A 2002 Chronicle article stated: "Healing Begins: Labor invites American Legion; honors both sides of Centralia event." In the article, Mittge shared how Lewis County union leaders invited the American Legion to "lay roses on Centralia's Sentinel statue" during the Labor day festivities that year. ${ }^{77}$ Weil's students may have never experienced the "conflict" of Centralia because, reconciliation of a kind had occurred. As Bob Guenther, the head of the Thurston-Lewis Labor Council, asserted, "Let's quit squabbling about something that happened 80 years ago. There are too many young people around here who need good jobs to not shoot for the future."${ }^{, 78}$

That the event has not received more attention was striking, because it was $a$ public reconciling between adherents of two of the frameworks. It certainly was influential, as evidenced by Mittge's later sensibilities about Tragedy memory (described in the Epilogue) and should have provided closure. Greater acknowledgement of a reconciling may have stemmed further chatter of an ongoing secret. Or it may have tempered the concerns that people like Peter Kardas from the Evergreen State College Labor Center had about conducting commemorative activities. It might have been transitory, however, a fleeting gesture that was not enshrined in any permanent way in that public contested space. Further, and germane to this thesis, it was only a convergence of two of the three frameworks: the academic memory was absent.

\footnotetext{
${ }^{76}$ Susanne Weil (Centralia College English professor), in discussion with author, October 15, 2012. A present day search on Google for "Centralia, Washington" does not return any Tragedy results. If "history" is added to the search terms, however, it appears in several selections. One thing to consider is how often any teenager does an Internet search of their hometown...

${ }_{77}$ Brian Mittge. "1919 massacre remembered." Centralia Chronicle (Centralia, WA), September 3, 2002. ${ }^{78}$ Ibid.
} 
Academics, Weil included, missed any mention of it because it is not included in the Timberland Library's extensive collection of print outs, nor the University of Washington or Centralia College's vast Centralia Tragedy holdings. Instead the story is buried in the Chronicle's microfilm, available only at the Timberland library. ${ }^{79}$ Weil's research on the event, including trips to the Oregon Historical Society and a short paper delivered at the 2013 Pacific Northwest Labor History Conference, led her to an understanding based mainly on the Labor countermemory framework, which makes sense considering the collections at the Historical Society were formerly Ruuttila's possessions and Walden's donation dominates what's presently stored at Centralia College. That framework also dominates popular history (Loewen) and what the amateur researcher finds when doing the most preliminary research on the Internet. As such, it is no surprise that, when Weil arranged for a series of events on the $90^{\text {th }}$ anniversary of the Tragedy, it was heavily partial to the Labor framework. Along with tours of key Tragedy sites, there were talks by Labor historians Laurie Mercier of Washington State University and Aaron Goings of St. Martin's University, a showing of Fischel's documentary, and readings sponsored by the Labor Studies Center at Evergreen State College. ${ }^{80}$

The only evidence of the official memory framework at Weil's Lyceum was a talk by the local chaplain of the American Legion, Dr. Earl Nordby. Nordby, as the representative of the Centralia Grant Hodge Post, was a newcomer to Centralia, and like

\footnotetext{
${ }^{79}$ After several years of research on the Tragedy, I only discovered this incident on my final visit to Centralia to conduct fact checking. It was an entirely unexpected discovery, as no conversation or later article references its occurrence.

${ }^{80}$ Neither speaker gave a talk directly on Centralia. Both spoke about Labor in the Northwest more in general, which, in a way, avoided a public conflict between the Labor countermemory framework and the academic framework.
} 
Weil, researched the event as an outsider. ${ }^{81}$ Because of his scant experience, Nordby simply recapped events from 1919 and explained the Legionnaire's historical position. Nordby didn't apologize for the American Legion or have any splashy revelation on who lynched Everest. It is thus hard to think of the official memory framework at the Lyceum being anything close to the robust presence it had been in Centralia. Intriguingly he titled his lecture the "Legionnaire-Wobbly Catastrophe" not "Massacre" or "Tragedy." As mentioned in this thesis's introduction, what one calls the 1919 event tends to reflect their bias. Historically, "massacre" tends to be associated with the Labor countermemory while "riot" tends to follow along the official memory. Never before had "catastrophe" been used, which may have symbolized a new, distant position for the Legion within the memory frameworks. ${ }^{82}$

In recalling the 2009 Lyceum, Weil noted a few particular details relevant to this study. She remembered that the composition of the programs's audiences varied greatly by event. Nordby's talk, she remembered, was the most heavily attended and contained the largest percentage of Centralians. Possibly, those attending were looking for either a defense of the official memory framework or some type of revelation on the part of the Legion. Otherwise, Labor-friendly audiences attended most talks. This irked many of the native Centralians, who claimed the Labor folks would not let the story go. ${ }^{83}$

\section{The primacy of countermemory}

\footnotetext{
${ }^{81}$ Earl Nordby, "Veterans Attacked by Wobblies: the November 1919 Legionnaire-Wobbly Catastrophe." Centralia College Lyceum, November 25, 2009.

${ }^{82}$ Ibid; Weyeneth, 66. This conversation is referenced in the introduction of this thesis on page 6 in the footnotes.

${ }^{83}$ Susanne Weil (Centralia College English professor), in discussion with author, October 15, 2012.
} 
In the early 1990 s, the ability of the Labor countermemory to supplant the official memory framework of the Centralia Tragedy seemed remote. Countless efforts, waged by writers, activists, folklorists and playwrights had failed to dislodge the primacy of the Sentinel. Labor's contemporary ascendance, be it temporary or sustained, can be attributed to a series of important events in the span of the past 25 years, both directly related to the Centralia Tragedy and more from the context of everyday life.

Both the Weyeneth experience and Viles controversy taught Labor countermemory adherents much about the way they needed to proceed in order to establish their authority. First, they needed to abandon any attempt at balance, either with the official memory or the academic memory frameworks. Weyeneth garnered no momentum inside of Centralia for any sort of change, and that was directly attributable to his effort to include both the Sentinel and Wesley Everest's grave in the national historical register. The two sites are not equally prominent or visible, however, due to the remote location of the grave. The controversy needed to be brought to the public space in Centralia, which was evidenced by the uproar about Viles's marker. Labor countermemory framework adherents realized Weyeneth was right to choose Everest as the counterpoint to the Sentinel, and that Viles was right to challenge the statue where it was situated. As such, they created their mural of Everest, made it glower over the Sentinel, and in doing so, united previously disparate elements of the community. That effort broke the previous hegemony of the official memory framework.

Yet, this effort would not have succeeded were it not for background developments. The consistent economic misfortune in Centralia began to steer small business owners, previous bulwarks against Labor, toward supporting that mural and its 
economic tourism potential. The Grant Hodge Post American Legion, who had even been able to muster national support to oppose the mural, retreated when fellow Centralians asked them to. And the Chronicle, easily the oldest voice against the Labor perspective, opted for détente in order to sell papers and remain viable. With all of its traditional allies gone, the Sentinel stood alone in George Washington Park against the Labor countermemory onslaught, and now stands under the command of the resurrected Wesley Everest.

And this is why, at this particular historical moment, the Centralia Tragedy, or more appropriately, what we collectively call the Centralia Massacre, is a Labor memory. 
Epilogue: The Tragedy Memory

In late July of 2014, I walked around Centralia with Brian Mittge, who left the Chronicle in 2013. Mittge showed me around the places he had researched for his Chronicle articles. He introduced me to shop owners along Tower Avenue and set up meetings with local residents who felt a particular connection to the Centralia Tragedy. When I met Mittge in Centralia, he had just come from an event where he had bumped into a few old friends. Since Mittge no longer worked or lived in Centralia, he seemed to enjoy the opportunity to return, and served as an intermediary for me. Armed with a copy of McClelland's text and the clippings of every Centralia article he had written, we went from the Timberland Library to lunch at the Olympic Club, which had been a prominent gathering spot for Centralia's elite in the 1910s.

Two longtime Centralians, Marshall and Margie Joy Murray, joined us at lunch. The Murrays shared their perspective on the massacre, giving a strictly Labor countermemory retelling. Marshall had, in 2012, organized a birthday party for Elmer Smith, which had been held at the Olympic Club. During the party, Murray arranged for a recording of Eugene Barnett to be played in the background. ${ }^{1}$ When asked about the reasons for planning the event, Marshall simply remarked, "Smith was someone that we should celebrate as a community."2 The event was well attended, according to Murray, and roused no opposition, again reflecting the authority of the Labor framework among Centralians.

\footnotetext{
1 "Birthday Party Planned for IWW's 'Fighting Lawyer."” Centralia Chronicle, January 26, 2012. Accessed at: http://www.chronline.com/records/article_c4589c46-4776-11e1-9261001871e3ce6c.html?mode=jqm (October 12, 2014).

${ }^{2}$ Marshall Murray (Centralia resident), in discussion with author, July 26, 2014.
} 
Further proof of the Labor framework's supremacy was evident with the White family's experience as owners of the Centralia Square Antiques Mall. After purchasing the building from John Regan, they cut out sections of the Wesley Everest mural for their hotel and event space. On the day I met with Mittge, he described for me how the Whites had some issues in doing this. According to Neil White, Regan insisted that if they were going to cut up the mural, they would have to find a way to maintain the complete image. ${ }^{3}$ While White publicly stated that he would find a way to do this, the Labor community was skeptical. Ron Verzuh, an officer in the Pacific Northwest Labor History Association, went so far as to call the renovation "cultural vandalism" and a travesty. ${ }^{4}$ Verzuh linked his condemnation to the Facebook page of Mike Alewitz, now at Central Connecticut State University, who posted, "This desecration of the mural by the owners of Centralia Square, is an insult to every working person. ${ }^{, 5}$ Consistent pressure led the Whites to commission artists to create coverings from perforated vinyl for his new windows that perfectly matched the mural. He also kept the original panels, which are on display on the second floor of the hotel. ${ }^{6}$

This is not to say that the other frameworks have disappeared. While we toured Centralia, Mittge told me that today opinions did not run so hot about the Tragedy, because he had seen "closure" events like the 2002 Labor Day commemoration. Yet, when we walked around Centralia, citizens disagreed with his assessment. Rebecca

\footnotetext{
${ }^{3}$ Brian Mittge (former Chronicle editor), in discussion with author, July 26, 2014. Neil White (Centralia Antiques Mall owner) in discussion with author, June 2, 2015.

${ }^{4}$ Ron Verzuh. "Centralia, WA, Wobbly mural defacement called a travesty." Oregon PNHLA Update, November, 2014.

${ }^{5}$ Mike Alewitz, "Labor Mural Defaced," blog post, August 20, 2014, https://www.facebook.com/photo.php?fbid=10204596202722517\&set=a.4929515233194.2208261.115786 6386\&type $=1 \&$ theater (accessed June 2, 2015).

${ }^{6}$ Neil White (Centralia Square owner), in discussion with author, June 2, 2015.
} 
Staebhler, the proprietor of Hubbub: Art for Everyday, corrected him when he asserted that the issues around the Tragedy were over. She insisted that there were plenty of Centralians for whom the issue was not settled. After prodding from Mittge, she maintained that there were plenty of people in town who shared her take. ${ }^{7}$

When we stopped at the Ayala Brothers Furniture store, which is in the same building as the former Elks Club, this was evident. Mittge introduced me to both Ayala Brothers, and asked if he and I could get a tour of the Club, which the brothers had been restoring until the 2007 economic collapse halted their work. Mittge mentioned my work on the Tragedy to the Ayalas, which prompted a third man sitting in the store to interject, "Why would someone from Portland want to know about the Massacre?" The man, Arthur Veach, explained that he was the current owner of F.H. Hubbard's house on N. Washington Avenue. Veach explained that he fully sided with the Legionnaires, and even sought and obtained National Register for his home, known as the "Hubbard Bungalow" in 2005 , on the premise that Hubbard was a historically significant individual. He and his wife, Glenda, who sat beside him, explained their stance a bit more, which interestingly, came across as a modernized version of the official memory framework. Rooted in a conservative criticism of unions in America, both husband and wife presented Hubbard sympathetically, as one of many local business leaders pressured by national forces, something the rank and file union member simply didn't understand. ${ }^{8}$

It was a notable moment because Veach was attempting to transmit a new version of the official memory framework, almost to spite the present-day hegemony of the Labor countermemory. And further, I should note, he was doing it to someone who believes he

\footnotetext{
${ }^{7}$ Rebecca Staebhler (Centralia business owner), in discussion with author, July 26, 2014.

${ }^{8}$ Arthur and Glenda Veach (F.B. Hubbard's former house owner), in discussion with author, July 26, 2014.
} 
represents the most recent incarnation of the academic framework, detached as I have been in completing this thesis. Here, in the old Elks Hall, in the face of nearly 20 years of building support for the Labor framework, the carriers of the other frameworks were trading chatter on their perspectives of the Tragedy. Upon reflection, I couldn't help but wonder if, twenty years from now, I'll be sitting at a ceremony, watching the Sentinel get a new sheen by a parade of Veach's grandchildren and a class of Centralia middle schoolers.

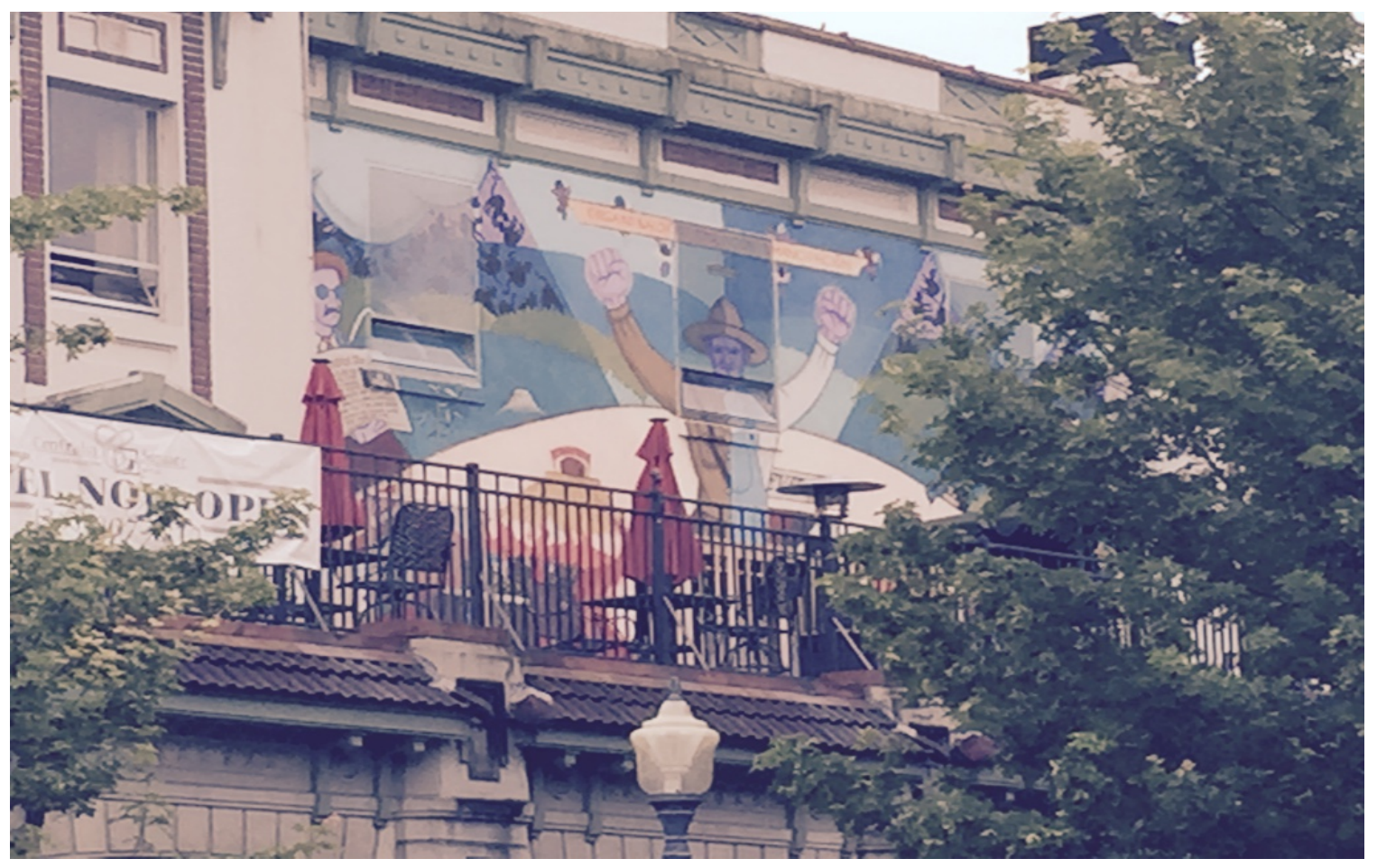

Fig. 15. Wesley Everest mural reconstructed, photo taken by the author, June 2, 2015. 


\section{Bibliography}

Books and Journal articles:

Anderson, Colin. "The Industrial Workers of the World in the Seattle General Strike," Strike: Seattle General Strike Project.

Chaplin, Ralph. The Centralia Conspiracy. 1920; reprint, Teddington, England: The Echo Library, 2007.

Churchill, Thomas. Centralia Dead March. Willimantic: Curbstone Press, 1980.

Copeland, Tom. The Centralia Tragedy of 1991: Elmer Smith and the Wobblies. Seattle: University of Washington Press, 1993.

Copeland, Tom. "Wesley Everest: I.W.W. Martyr.” Pacific Northwest Quarterly 77, no.4 (1986): 122-129.

Dubofsky, Melvyn. "Raising Less Corn and More Hell: Two Disciples of Mary Ellen Lease.” Reviews in American History 23, no. 2 (1995): 266-271.

Flink, Joe and Breckinridge, Ron. Centralia Tragedy Remembered: a textbook concerning a local history event for Centralia eighth graders. Centralia: Centralia School District, 1987.

Gunns, Albert. "Ray Becker, the Last Centralia Prisoner." Pacific Northwest Quarterly 59, no. 2 (1968): 88-99.

Halbwachs, Maurice. The Collective Memory. Translated by Francis Ditter and Vida Yazdi Ditter. New York: Harper's Row, 1980. Included in

History of Centralia. Centralia, WA: Centralia Community Development Program, 1955.

Irish, Kerry. "Eternal Vengeance: A History of the Centralia Massacre.” Master's thesis, University of Washington, 1989.

Jensen, Vernon. Lumber and Labor. New York: Farrar and Rinehart, 1945.

Lampman, Ben Hur. Centralia Trial and Tragedy. Centralia, WA: Grant Hodge American Legion Post, 1920.

Levy, Daniel, Ozick, Jeffery, and Vitnitzky-Seroussi, Vered. The Collective Memory Reader. Oxford: Oxford University Press, 2011.

Loewen, James. Lies Across America: What our Historic Sites Get Wrong. New York: 
Touchstone, 1999.

McClelland, John. Wobbly War: The Centralia Story. Tacoma: Washington State Historical Society Press, 1987.

McClelland, John. “Terror on Tower Avenue." Pacific Northwest Quarterly, 57, no. 2 (1966): 65-72.

Mittge, Brian. "Framing Tragedy: The Centralia Chronicle's Changing View of its 1919 Hometown Massacre.” University Scholar's Thesis, Seattle Pacific University, 2004.

Nelson, Eugene. Introduction to The Centralia Conspiracy. Austin: Work Place Publishers, 1973.

Nora, Pierre. "Reasons for the Current Upsurge in Memory." In The Collective Memory Reader, edited by Daniel Levy, Jeffrey Ozick, and Vered VitnitzkySeroussi, 437-442. Oxford: Oxford University Press, 2011.

Nordby, Earl. "Veterans attacked by Wobblies: The November 1919 LegionnaireWobbly Catastrophe." Presentation at the Centralia College Lyceum, Centralia, WA, November 25, 2009.

O’Conner, Harvey. Revolution in Seattle. New York: Monthly Review Press, 1964.

Patell, Cyrus. Negative Liberties: Morrison, Pynchon, and the Problem of Liberal Ideology. Durham: Duke University Press, 2001.

Rayback, John. A History of American Labor. New York: The Free Press, 1959.

Rousso, Henry. The Vichy Syndrome: History and Memory in France since 1944. Cambridge: Harvard University Press, 1991.

Skoog, Lawrence. "Labor Violence: The Centralia Case, the I.W.W. and its Enemies." Master's thesis, Portland State University, 1975.

Skoog, Lawrence, "The Centralia Case: Three Views of the Armistice Day Tragedy at Centralia, Washington, 1919 by Ralph Chaplin; Ben Hur Lampman.” Oregon Historical Quarterly 73, no. 1 (1972): 70-71.

Slough, Mary. "Centralia's Union Mural.” Columbia, the Magazine of Northwest History 13, no.3 (1999): 24-27.

Smith, Walker C. Was it Murder? Seattle: Northwest District Defense Committee, 1922. 
Taft, Philip, and Ross, Philip. "American Labor Violence: Its Causes, Character, and Outcome," in The History of Violence in America: A Report to the National Commission on the Causes and Prevention of Violence. ed. Hugh Davis Graham and Ted Robert Gurr, 1969.

"The Cold War and the Red Scare in Washington: Historical Context," Seattle: Center for the Study of the Pacific Northwest.

“The Red Scare in the 1920s: Collected Commentary," Washington: National Humanities Center, 2012.

Tyler, Robert. "Violence in Centralia, 1919." Pacific Northwest Quarterly 45, no. 4 (1954): 116-124

Walden, Eleanor. “A Wob Remembers.” Eleanor Walden Papers, Centralia College Kirk Library, Box 5.3.

Warner, W. Lloyd. The Living the Dead: A Study of the Symbolic Life of Americans. New Haven: Yale Historical Press, 1959.

Weinburg, Sam. Historical Thinking and Other Unnatural Acts. Philadelphia: Temple University Press, 2001.

Weyeneth, Robert. "History, He Wrote: Murder, Politics, and the Challenges of Public History in a Community with a Secret." Public Historian 16, no. 2 (1994): 51-73.

Wollner, Craig. "Wobbly War: The Centralia Story." Oregon Historical Quarterly 89, no. 3 (1988): 305-307.

Wyckoff, DeWitte. The Centralia Case, a joint report on the Armistice Day Tragedy at Centralia, Washington, November 11, 1919. Brooklyn: Brooklyn Eagle Press, 1930.

Zerubavel, Yael. Recovered Roots: Collective Memory and the Making of Israeli National Tradition. Chicago: University of Chicago Press, 1995.

\section{Letters and Documents}

"Body Found in Clearing," Newspaper excerpt, Ray Becker papers, Mss 2003, Folder 2/24, Oregon Historical Society Research Library. 
“Cynder Viles, Statement to the NCSS," FP-18, Faculty Papers, Lawrence L. Lowther. Archives and Special Collections, Brooks Library, Central Washington University.

"Letter from Julia Ruuttila to Union Leader, June 1, 1937," Ray Becker papers, Mss 2003, Folder 2/13, Oregon Historical Society Research Library.

"Letter from Julia Ruuttila to Albert Gunns, May 27, 1964," Ray Becker papers, Mss 2003, Oregon Historical Society Research Library.

"Letter from Julia Ruuttila to Albert Gunns, March 5, 1967," Ray Becker papers, Mss 2003, Oregon Historical Society Research Library

"Letter from Lawrence Lowther to Pascal Gilmore, June 30, 1992," FP-18, Faculty Papers, Lawrence L. Lowther. Archives and Special Collections, Brooks Library, Central Washington University.

“Letter from Ray Becker to Ralph Chaplin, Feb. 7, 1924," Ray Becker papers, Mss 2003, Folder 1/1, Oregon Historical Society Research Library.

“Letter from Ray Becker to Julia Godman Ruuttila,” Ray Becker papers, Mss 2003, Folder 1/1, Ray Becker papers, Oregon Historical Society Research Library.

"Letter from Richard Berner to Julia Ruuttila, Marcy 20, 1967," Ray Becker Papers, Mss 2003, Oregon Historical Society Research Library.

"Prosecution and Defense Witness Lists - List of Suspected Lynchers," Ray Becker papers, Mss 2003, Folder 1/28, Oregon Historical Society Research Library.

“Resolution No. 140," Seventy-Ninth National Convention of the American Legion.

“Simon Hill Affidavit, 1936," Ray Becker papers, Mss 2003, Folder 2/5, Oregon Historical Society Research Library.

\section{Newspapers:}

Centralia Chronicle (and Daily Chronicle), Dec. 5, 1919; Nov. 10, 1924; Nov. 11, 1963; Aug. 14, 1991; Aug. 21, 1991; Jan. 22, 1992; Jan. 24, 1992; Jan. 29, 1992; Feb. 4, 1992; Feb. 12, 1992; Feb. 14, 1992; Nov. 2, 1994; Oct. 25, 1997; Oct. 30, 1997; Sep. 3, 2002;

Nov. 10, 2009; Jan. 26, 2012; Apr. 22, 2014

Centralia $H u b$, June 26, 1919.

The Columbian, Dec. 16, 1997. 
The Oregonian, Nov. 15, 1919.

The New York Times, Nov. 16, 1919; Jan. 24, 1920.

Northeast Bay Independent and Gazette, June 17, 1980.

The Tacoma News Tribune, Nov. 13, 1919.

Seattle Post-Intelligencer, Nov. 18, 1979.

Seattle Times, Oct. 27, 1976; Jan. 22, 1989; Mar. 10, 1997; Nov. 11, 1999.

Washington Free Press, Mar/Apr 1998

Oral Histories/Interviews:

Edward Coll, interview by Eleanor Walden, June 26, 1979. Available through the Centralia College Kirk Library

Margaret Shields, interview by author, October 2012.

Susanne Weil, interview by author, October 15, 2012

Albert Gunns, interview by author, June 5, 2014.

Sandy Polishuk, interview by author, June 10, 2014.

Brian Mittge, interview by author, July 26, 2014.

Marshall Murray, interview by author, July 26, 2014.

Rebecca Staebhler, interview by author, July 26, 2014.

Arthur and Glenda Veach, interview by author, July 26, 2014.

Anne Fischel, interview by author, September 26, 2014.

Eleanor Walden, interview by author, May 21, 2015.

Neil White, interview by author, June 2, 2015. 
Films:

Lewis County: Hope and Struggle. Directed by Anne Fischel. 2004. Olympia, WA: Right to Know Productions, 2007. DVD.

The Peaceful Parade. Directed by Hugh Crawford. 1993. Seattle, WA. Pro-Pictures, 1994. DVD. 